\title{
DISTRIBUIÇÃO TERRITORIAL DOS DESEMBOLSOS DO BNDES PARA A INDÚSTRIA E A INFRAESTRUTURA
}

ENTRE 2000 E 2018

Raphael de Oliveira Silva Mabel Diz Marques
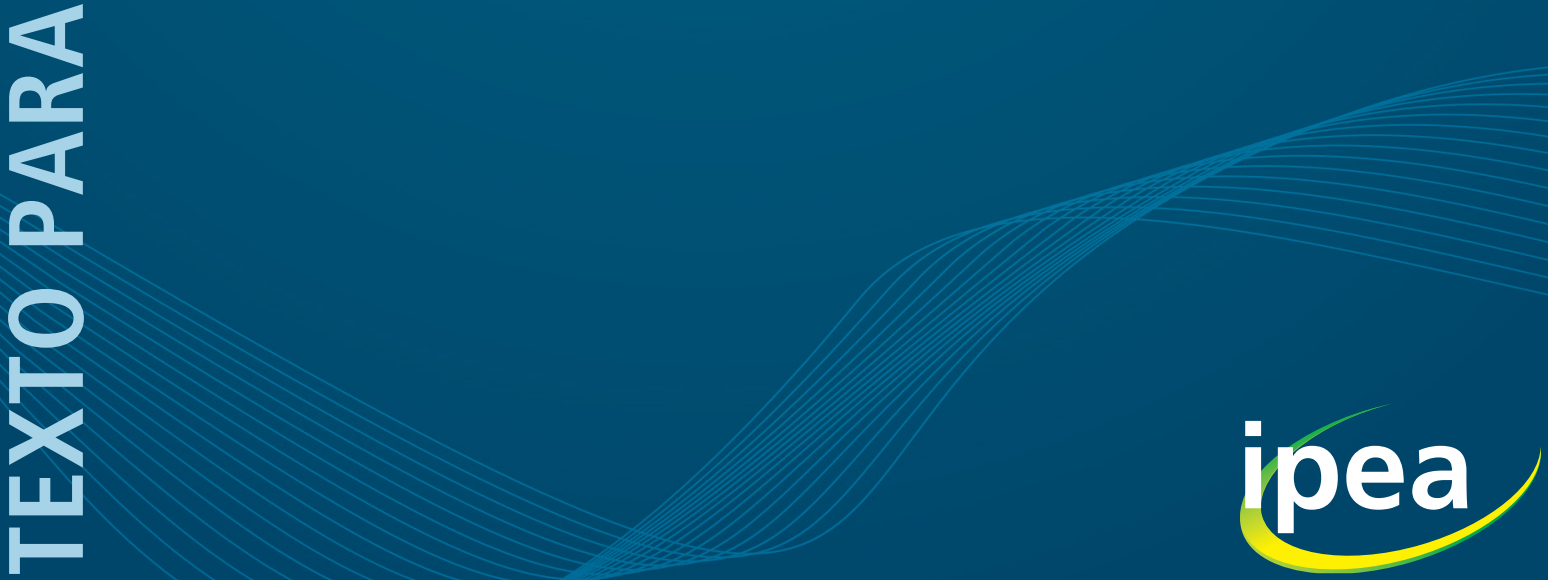



\section{TEXTO PARA DISCUSSÃO}

Brasília, janeiro de 2021

\section{DISTRIBUIÇÃO TERRITORIAL DOS DESEMBOLSOS DO BNDES PARA A} INDÚSTRIA E A INFRAESTRUTURA ENTRE 2000 E 2018

Raphael de Oliveira Silva'

Mabel Diz Marques

1. Pesquisador associado da Diretoria de Estudos Regionais, Urbanos e Ambientais (Dirur) do Ipea.

2. Pesquisadora do Grupo de Pesquisa Unidade de Estudos Setoriais da Faculdade de Economia da Universidade Federal da Bahia (FE/UFBA). 


\section{Governo Federal \\ Ministério da Economia \\ Ministro Paulo Guedes}

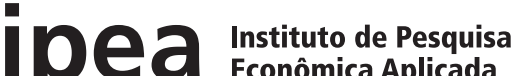 Econômica Aplicada}

Fundação pública vinculada ao Ministério da Economia, o Ipea fornece suporte técnico e institucional às ações governamentais - possibilitando a formulação de inúmeras políticas públicas e programas de desenvolvimento brasileiros - e disponibiliza, para a sociedade, pesquisas e estudos realizados por seus técnicos.

\section{Presidente}

Carlos von Doellinger

Diretor de Desenvolvimento Institucional

Manoel Rodrigues Junior

Diretora de Estudos e Políticas do Estado, das Instituições e da Democracia

Flávia de Holanda Schmidt

\section{Diretor de Estudos e Políticas}

Macroeconômicas

José Ronaldo de Castro Souza Júnior

Diretor de Estudos e Políticas Regionais, Urbanas e Ambientais

Nilo Luiz Saccaro Júnior

Diretor de Estudos e Políticas Setoriais de Inovação e Infraestrutura

André Tortato Rauen

Diretora de Estudos e Políticas Sociais

Lenita Maria Turchi

Diretor de Estudos e Relações Econômicas

e Políticas Internacionais

Ivan Tiago Machado Oliveira

\footnotetext{
Assessor-chefe de Imprensa

e Comunicação (substituto)

João Cláudio Garcia Rodrigues Lima

Ouvidoria: http://www.ipea.gov.br/ouvidoria

URL: http://www.ipea.gov.br
}

\section{Texto para Discussão}

Publicação seriada que divulga resultados de estudos e pesquisas em desenvolvimento pelo Ipea com o objetivo de fomentar o debate e oferecer subsídios à formulação e avaliação de políticas públicas.

(C) Instituto de Pesquisa Econômica Aplicada - ipea 2021

Texto para discussão / Instituto de Pesquisa Econômica Aplicada.- Brasília : Rio de Janeiro : Ipea, 1990-

ISSN 1415-4765

1.Brasil. 2.Aspectos Econômicos. 3.Aspectos Sociais. I. Instituto de Pesquisa Econômica Aplicada.

CDD 330.908

As publicações do Ipea estão disponíveis para download gratuito nos formatos PDF (todas) e EPUB (livros e periódicos). Acesse: http://www.ipea.gov.br/portal/publicacoes

As opiniões emitidas nesta publicação são de exclusiva e inteira responsabilidade dos autores, não exprimindo, necessariamente, o ponto de vista do Instituto de Pesquisa Econômica Aplicada ou do Ministério da Economia.

É permitida a reprodução deste texto e dos dados nele contidos, desde que citada a fonte. Reproduções para fins comerciais são proibidas.

JEL: R11; G32; L50; 020. 


\section{SUMÁRIO}

SINOPSE

ABSTRACT

1 INTRODUÇÃO 7

2 ATUAÇÃO DO BNDES .8

3 EVOLUÇÃO E DISTRIBUIÇÃO DOS DESEMBOLSOS SOBRE A INDÚSTRIA .... .13

4 TRAJETÓRIA DOS DESEMBOLSOS SOBRE A INDÚSTRIA NAS AGLOMERAÇÕES PRODUTIVAS RELEVANTES E POTENCIAIS

5 EVOLUÇÃO E DISTRIBUIÇÃO DOS DESEMBOLSOS SOBRE A INFRAESTRUTURA. 38

6 TRAJETÓRIA DOS DESEMBOLSOS SOBRE A INFRAESTRUTURA NAS AIRs E AIPs......43

7 CONCLUSÕES

REFERÊNCIAS .63

BIBLIOGRAFIA COMPLEMENTAR 67 



\section{SINOPSE}

Este estudo tem como objetivo investigar a dinâmica e os padrões de distribuição dos desembolsos do Banco Nacional de Desenvolvimento Econômico e Social (BNDES) para a indústria e a infraestrutura, com ênfase nos vetores setoriais e regionais de sua atuação no Brasil. A abordagem está fundamentada no uso do método analítico, descritivo e estatístico, e a base de dados é proveniente do BNDES e da Relaçáo Anual de Informaçóes Sociais (Rais) para o período 2000-2018. Os resultados sugerem que o BNDES, no período recente, ampliou o financiamento da indústria e infraestrutura brasileira em todas as macrorregióes, demonstrando, ainda que em escala modesta, um processo de desconcentração. As aglomeraçôes industriais mais consolidadas ainda preservam grande relevância na absorção dos recursos (tanto para indústria quanto para a infraestrutura), e estâo localizadas, principalmente, na proximidade das principais capitais e da faixa litorânea. Entretanto, os resultados deixam evidente uma atuação do BNDES em prol das aglomeraçôes de menor tamanho, sobretudo aquelas pertencentes às regióes alvo da política regional (Norte, Nordeste e Centro-Oeste), processo este que pode refletir em edificação de novos arranjos produtivos locais.

Palavras-chave: BNDES; financiamento; indústria de transformação; infraestrutura; desenvolvimento regional.

\section{ABSTRACT}

This study aims to investigate the patterns and patterns of distribution of funds from the National Bank for Economic and Social Development (BNDES) on industry and infrastructure, with emphasis on the sectorial and regional vectors of its performance in Brazil. The approach is based on the use of analytical, descriptive and statistical methods and based on data that are registered by the BNDES and the Annual List of Social Information (RAIS) for the period 2000-2018. The results suggested for the BNDES in the most recent period, expanded the financing of the Brazilian industry and infrastructure in all macro-regions, demonstrating, even on a modest scale, a process of deconcentration. As more consolidated industrial agglomerations, they still retain great relevance in the absorption of resources (both for industry and infrastructure) and are located, mainly, in the proximity of the main capitals and coastal strip. However, the results are 
evident when the BNDES carries out actions of smaller size agglomerations, mainly those belonging to regions targeted by the regional policy (North, Northeast and Midwest), a process that can be considered in the edition of new local productive arrangements.

Keywords: BNDES; financing; transformation industry; infrastructure; regional development. 


\section{INTRODUÇÃO}

Identificado como um dos três maiores bancos de desenvolvimento do mundo ${ }^{1}$ (Guedes, 2018) e controlado integralmente pela União, o BNDES é o principal instrumento do governo federal para financiar investimento de longa maturação no Brasil (Diniz, 2002), sobretudo para a infraestrutura e a indústria (Barboza, Furtado e Gabrielli, 2018). Uma instituição com a sua vocação de financiamento possibilita a preservação da capacidade de transformar as estruturas no território, ativando e estimulando atividades produtivas locais, o que favorece o progresso econômico e social mais equitativo.

Nesse contexto, o estudo parte da seguinte problemática: qual o padrão distributivo dos desembolsos do BNDES para a indústria (extrativa e de transformação) no período recente (2000-2018)? Quais regióes foram mais beneficiadas no período? Houve uma mudança no padrão histórico de centralidade no Sudeste do país? A atuação está pautada em aglomeraçóes industriais mais consolidadas ou naquelas que apresentam potencialidade? No que toca à infraestrutura, característica que confere ao território maior competitividade ante os demais, existiu um esforço em financiar novas áreas, para além das regióes mais desenvolvidas (Sul e Sudeste)? Para responder a estas questóes, objetiva-se apresentar a evolução dos desembolsos no território em múltiplas escalas, segundo os setores, as macrorregiōes, as Unidades Federativas (UFs), as microrregiôes geográficas e o tamanho do emprego industrial. A abordagem está fundamentada no uso do método analítico, descritivo e estatístico, e a base de dados é proveniente do BNDES e da Rais para o período 2000-2018.

Tendo em vista que o BNDES visa ampliar a dinâmica das transformações estruturais e reduzir as disparidades regionais - especialmente a partir de 2007, quando foi incorporada explicitamente pela instituição a questão regional no planejamento corporativo e estratégico, e reiterado em sua missão na busca pela promoção do desenvolvimento sustentável da economia brasileira (Lastres et al., 2014) -, a hipótese defendida é que a atuação do BNDES foi ampliada para além das regióes industriais maduras.

1. Os dois maiores são, respectivamente, o China Development Bank (CDB) e o alemão Kreditanstalt für Wiederaufbau (KFW). 
A análise da indústria sob o ponto de vista do olhar no território justifica-se pela incontestável dinâmica que o setor manufatureiro proporciona às economias capitalistas modernas (Kaldor, 1966; Thirlwall, 1983; Libânio e Moro, 2009; Marconi, Reis e Araújo, 2014). Uma vez que as atividades econômicas, inerentes à indústria, fomentam tanto a expansão dos níveis de produtividade e competitividade como os encadeamentos setoriais a jusante e a montante (Furtado, 1968). Além disso, foi na indústria de transformação (em paralelo ao setor de infraestrutura) que historicamente houve os maiores vultos em termos de desembolsos do banco (BNDES, 2019).

A relevância do tema parece ser o grande impulsionador da literatura que analisa a atuação do BNDES. Trabalhos recentes têm buscado avaliar sua atuação no território (Lastres et al., 2014; Quaglio e Paiva, 2017), suas fontes de recursos (Prochnik e Pereira, 2008), seus impactos sobre o investimento das firmas apoiadas (De Negri, De Negri e Alvez, 2008; Machado e Roitman, 2015; Barboza, Furtado e Gabrielli, 2018), entre outros, vis-à-vis as políticas econômicas determinadas pelo Estado brasileiro. Desta forma, o artigo se insere na literatura buscando identificar o padrão da atuação do BNDES na atividade industrial e na infraestrutura, no território em múltiplas escalas.

Nesse contexto, o trabalho está estruturado em cinco seçóes, além desta introdução e das considerações finais. Na segunda seção é apresentada uma breve contextualização histórica da atuação do BNDES como uma instituição financeira de desenvolvimento (IFD) que busca fomentar o desenvolvimento econômico. Na terceira seção são apresentadas a evolução e a distribuição dos desembolsos entre as atividades industriais, as macrorregiôes e as UFs. $\mathrm{Na}$ quarta seção são expostas as trajetórias regionais de atuação do BNDES, com ênfase sobre o volume de recursos aplicados na indústria, nas aglomeraçóes produtivas relevantes e potenciais, segundo o tamanho do emprego industrial. A quinta seção apresenta a evolução e a distribuição dos desembolsos na infraestrutura. Por fim, é exposta a trajetória dos desembolsos na infraestrutura nas aglomeraçôes produtivas relevantes e potenciais.

\section{ATUAÇÃO DO BNDES}

A problemática do financiamento em países em desenvolvimento é um fato relevante, sobretudo no Brasil, onde há um histórico de escassez de financiamento de longo prazo, em particular para regióes de baixo dinamismo econômico e para aqueles setores econômicos que denotam baixa rentabilidade e longo período de maturação. 
Identificado como um dos três maiores bancos de desenvolvimento do mundo (Guedes, 2018) e controlado integralmente pela Uniáo, o BNDES, apesar de operar sob orientação mais setorial que regional dos investimentos, é o principal instrumento de financiamento da atividade produtiva no país (Diniz, 2002).

A análise da atuação do banco permite identificar que o rebatimento espacial de seus apoios ocorreu, majoritariamente, em função dos projetos nacionais vigentes. Para exemplificar essa condição, entre 1952 e 1960, a infraestrutura representava 69,3\% das aprovaçóes (centradas principalmente em ferrovias e energia); seguida pela indústria, com 28,4\%. Nos anos de 1961 a 1970, em meio ao Plano de Metas, a instituição se consolidou como banco da indústria nacional, pois a participação da indústria nas aprovaçôes da instituição alcançou 70,6\% na década de 1960, enquanto a infraestrutura reduziu sua participação para 25,2\% (Barboza, Furtado e Gabrielli, 2018). Nesse período o apoio estava voltado para o fortalecimento das estruturas e dos financiamentos necessários para o desenvolvimento da atividade industrial do país, centrada, sobretudo, na regiāo Sudeste do país (Lastres et al., 2014).

Na década de 1970, o II Plano Nacional de Desenvolvimento (II PND) previa, entre as diretrizes da política industrial, a diretriz de desconcentração industrial. De acordo com a Resolução n ${ }^{\ominus} 14$ do Conselho de Desenvolvimento Econômico (CDE), em primeiro lugar, deveriam ser fortalecidas as plantas industriais do Rio de Janeiro, de Minas Gerais e da regiáo Sul do país. O Nordeste, por sua vez, receberia prioridade quanto aos complexos industriais instalados na região, devido à significância já assumida pela industrialização no desenvolvimento regional. Ao passo que às regiôes Norte e Centro-Oeste do país estaria reservada, prioritariamente, a implementação de complexos agroindustriais e minero-industriais. Finalmente, para São Paulo, a resolução destacava a atuação no sentido da melhoria da qualidade de vida urbana na região metropolitana (RM), para onde deveriam ser aprovados, pelos órgáos gestores e de financiamento, projetos industriais (Codato, 1997). No período entre 1971 e 1980, a composiçáo do apoio do BNDES manteve o protagonismo da indústria nos financiamentos do banco (participação de 67,4\%), enquanto a infraestrutura se manteve como o segundo setor mais relevante - participação de 27,0\% (Barboza, Furtado e Gabrielli, 2018).

Entre 1981 e 1990, a participação setorial manteve o mesmo ordenamento do decênio anterior, mas há uma clara diversificação no apoio, com uma redução da participaçáo da indústria de $67,4 \%$ para $57,4 \%$, bem como incremento no apoio ao setor 
de comércio e serviços, que saiu de 5,6\% para 11,1\%. Nos anos 1990 o BNDES passou por profundas mudanças, associadas à emergência de uma novo modelo de desenvolvimento, com a redefinição do papel do Estado na condução do desenvolvimento econômico, ao lado da abertura econômica e da estabilização monetária. Nesse processo o BNDES tornou-se instrumento central no Plano Nacional de Desestatização (PND), como agente financeiro dos programas de desestatização, no âmbito federal, estadual e municipal (Barros e Goldenstein, 1997). Nesse período a composição setorial de sua atuação é marcada pelo aumento da participação do setor agropecuário, que passa a representar $11 \%$ do apoio, o que corresponde a um aumento de quase 10 pontos percentuais (p.p.) em relação ao decênio anterior. A contrapartida desse aumento foi novamente a reduçáo do setor industrial, que, não obstante, continuou sendo relevante, representando 48\% do apoio do banco (Barboza, Furtado e Gabrielli, 2018).

Adicionalmente, ainda na década de 1990, visando induzir a desconcentração dos investimentos, o BNDES utilizou a oferta de condiçóes financeiras mais favorecidas, expressas em menor custo, maior prazo e maior participação do financiamento no investimento. Exemplares dos esforços foram organizados sob a forma de programas regionais, tais como Programa Nordeste Competitivo, Programa Amazônia Integrada, Programa de Apoio à Metade Sul do Rio Grande do Sul e Programa Centro-Oeste (Lastres et al., 2014).

Nos anos 2000, muito embora o perfil setorial manifestasse relativa estabilidade até 2010, com a predominância do financiamento da atividade industrial, o volume dos desembolsos do BNDES aumentou significativamente (Barboza, Furtado e Gabrielli, 2018). O Fundo Social, criado em 1997, visando apoiar majoritariamente projetos de assistência social, educação e saúde (BNDES, 1997), foi reformulado ao longo da primeira década dos anos $2000 .^{2}$ A sua prioridade deixou de ser a assistência social e passou a ser a reduçáo da desigualdade social e econômica, por meio do apoio a investimentos produtivos cooperativos capazes de induzir a geraçáo de trabalho e renda, sobretudo em áreas de baixa renda.

Os programas regionais estabelecidos na década de 1990 foram substituídos pelo Programa de Dinamização Regional (PDR), que, embasado na metodologia da Política Nacional de Desenvolvimento Regional (PNDR) - criada em 2004 e institucionalizada a por meio do Decreto ${ }^{\ominus} 6.047$ de 2007 -, abandonou o enfoque nas macrorregióes

2. Fazem parte dessa reformulação o conjunto de resoluções publicadas no período, tais como Resolução no 1.069/2003, Resolução no 1.167/2005, Resolução no 1.168/2005, Resolução no 1,592/2008 e Resolução no 1,654/2008. 
e passou a oferecer melhores condiçóes financeiras a empreendimentos localizados em municípios contidos em espaços prioritários elencados na tipologia da $\mathrm{PNDR}^{3}$ (Lastres et al., 2014). Ademais, em 2007, após ter incorporado o objetivo de contribuir para o desenvolvimento regional integrado e de longo prazo em sua missáo, o BNDES passou, então, a inserir a questão regional em seu planejamento corporativo, suas estratégias e sua estrutura organizacional.

Ainda nos anos 2000, o BNDES amplia veementemente os seus desembolsos, sobretudo a partir de 2007, tornando-se um importante agente de crédito para um conjunto de programas do governo federal, como o Programa de Aceleração do Crescimento (PAC), a Política de Desenvolvimento Produtivo (PDP, 2008-2010), o Programa de Sustentação do Investimento (PSI, 2009-2015) e o Plano Brasil Maior (PBM, 2011-2014).

O PAC, criado em 2007 e reformulado em 2011, buscou elevar o crescimento econômico com base na ampliação da taxa de investimento em vários projetos no país, em infraestrutura, energia, habitação, recursos hídricos e logística. Ao passo que a PDP detinha um enfoque para a atividade industrial, visando: i) ampliar a capacidade de oferta para enfrentar uma demanda em expansão; ii) preservar a robustez do balanço de pagamentos, mantendo a sustentabilidade das exportaçóes e evitando a restriçáo ao crescimento; iii) elevar a capacidade inovativa das empresas brasileiras, com intuito de ampliar a competitividade no mercado interno e fortalecer a inserção externa; e iv) alargar as condições de acesso a mercados externos para micro e pequenas empresas (Almeida, 2008).

No aspecto setorial, a PDP estabeleceu 25 setores prioritários, divididos em três grupos de programas: i) os Programas para Fortalecer a Competitividade, pautados nos ramos de bens de capital seriados, bens de capital sob encomenda, complexo automotivo, complexo de serviços, construção civil, couro, calçados e artefatos, indústria aeronáutica, indústria naval, madeira e móveis, plásticos, sistema agroindustrial, higiene pessoal, perfumaria e cosméticos; ii) os Programas Mobilizadores em Áreas Estratégicas,

3. A PNDR, visando à redução das desigualdades de nível de vida entre as regiões brasileiras e a promoção da equidade no acesso a oportunidades de desenvolvimento, que deve orientar os programas e as ações federais em todo o território nacional (Brasil, 2007), estabeleceu critérios para elencar os espaços prioritários para a ação da política regional. Com base nas variáveis de rendimento domiciliar médio e crescimento do produto interno bruto (PIB) per capita, foi construída uma tipologia das microrregiões, classificadas em alta renda, dinâmicas, estagnadas e de baixa renda (Brasil, 2004). 
voltados para os setores de nanotecnologia, biotecnologia, complexo da defesa, complexo industrial da saúde, energia, tecnologias de informação e comunicação; e, por fim, iii) os Programas para Consolidar e Expandir a Liderança, ligados às atividades de celulose, mineração, siderurgia, indústria têxtil, confecçôes e carnes (Almeida, 2008). No âmbito regional a política previa uma articulaçáo com a Política Nacional de Arranjos Produtivos Locais e a promoção de atividades produtivas no entorno de projetos industriais e de infraestrutura, com o objetivo de ampliar a participaçáo dos financiamentos no Nordeste até 2010 (Almeida, 2008).

Por seu turno, o PSI foi uma política anticíclica proposta para mitigar os efeitos da crise do subprime (2007/2008), tendo sido iniciado em julho de 2009 e encerrado em dezembro de 2015. O BNDES apoiou fortemente este programa, que buscou reduzir os custos dos financiamentos para a produção, a aquisição e a exportaçáo dos segmentos de bens de capital e inovação tecnológica, bem como alongou os prazos de amortização e carência para utilizaçáo dos recursos (BNDES, 2011). Segundo Albuquerque et al. (2018) e Ferraz, Além e Madeira (2013), no período a necessidade de recursos adicionais era essencial para viabilizar a expansão dos desembolsos e atingir as diretrizes das medidas anticíclicas na busca pela retomada do investimento. Neste contexto, o governo optou por capitalizar o BNDES, com recursos do Tesouro Nacional (TN), uma vez que os recursos do Fundo de Amparo ao Trabalhador (FAT) destinados ao financiamento de programas de desenvolvimento econômico não seriam suficientes para fazer frente à forte expansão do crédito. Contudo, a partir de 2013, as críticas à política fiscal e à atuação do BNDES foram constantes. Entre elas, destaca-se a elevada dependência do BNDES em relação aos recursos do TN, que refletia no elevado custo fiscal para a sociedade, uma vez que os investimentos agregados da economia brasileira não respondiam mais à expansão dos desembolsos.

O Programa Brasil Maior (PBM) buscava a mudança de posição relativa na economia mundial, e para isso tinha como estratégia: i) aumentar a capacidade de resistência da economia nacional e ocupar novos espaços em um mundo de baixo crescimento e protecionismo crescente; ii) utilizar os termos de intercâmbio favoráveis para construir liderança e comando em redes de inovação, produção e distribuição de segurança alimentar, energética e ambiental para o mundo; iii) desenvolver segmentos e cadeias produtivas de alto valor agregado, intensivos em conhecimento; e iv) garantir um crescimento ambientalmente sustentável. 
Entretanto, a partir de 2015, em meio à crise político-econômica no Brasil e com a mudança de governo, em maio de 2016, houve uma mudança de orientação e magnitude da atuação do BNDES. A instituição passou a reduzir sensivelmente seus desembolsos, retornando a patamares próximos ao observado na segunda metade da década de 1990 (Barboza, Furtado e Gabrielli, 2018). Para além dos efeitos do desaquecimento da economia sobre a demanda por crédito da instituiçáo, outros dois fatores podem ser elencados para a redução da atuação: i) a aprovação da nova taxa de juros de referência de seus empréstimos, a Taxa de Longo Prazo (TLP), estabelecida na Medida Provisória n ${ }^{\star} 777 / 2017$, que elevou a taxa de juros para um nível mais próximo do praticado no mercado; e ii) a decisão sobre o pagamento antecipado dos empréstimos ao Tesouro Nacional - entre 2015 e 2019, o banco antecipou o pagamento de mais de $\mathrm{R} \$ 431$ bilhóes $^{4}$ à instituição, o que se traduz na diminuição de sua capitalização (BNDES, 2018; 2019; Pereira e Miterhof, 2018).

Desse modo, o BNDES tem atuado como um artífice para políticas específicas de desenvolvimento do país, auxiliando na formulação de possíveis soluções para a retomada do crescimento econômico e a mitigaçáo das desigualdades regionais.

\section{EVOLUÇÃO E DISTRIBUIÇÃO DOS DESEMBOLSOS SOBRE A INDÚSTRIA}

Esta seção apresenta e discute a atuação do BNDES, expondo os resultados referentes à evolução e à distribuição dos desembolsos da instituiçâo para a indústria (extrativa e de transformação) entre os setores e as macrorregióes, entre os anos de 2000 e 2018. Para tanto, foi utilizada a fonte de dados de desembolsos por municípios especificados e atividades industriais segundo a Classificação Nacional de Atividades Produtivas (CNAE) 2.0 e o Índice Geral de Preços (IGP), da Fundaçáo Getúlio Vargas (FGV), para deflacionar a série de dados.

Ao analisar a evolução dos desembolsos totais e da indústria, observam-se dois comportamentos bem definidos (gráfico 1 e tabela 2). Inicialmente, o período compreendido entre 2000 e 2009, que foi marcado por uma trajetória de ascensão dos

4. Valor corrente. 
desembolsos totais e para a indústria e que está associado ao ciclo de crescimento da economia nacional no período e às iniciativas por parte do governo federal, como o PAC, a PDP (2008-2010) e o início do PSI (2009-2015).

Por seu turno, entre 2010 e 2014 - período marcado pelas consequências da crise internacional de 2008/2009, como a redução do crescimento da economia mundial e nacional, a queda no preço das commodities e o aumento das taxas de operaçôes do PSI -, os desembolsos totais mantiveram-se em patamar elevado, até final deste período. Muito embora tenha apresentado uma queda em 2011, em meio a uma preocupação do Banco Central com o aumento da inflação, no ano seguinte houve a retomada do crescimento do financiamento, que se alonga até 2013 (Puga e Gabrielli, 2018). Apesar da dinâmica nos desembolsos totais, os recursos destinados à indústria já começavam a apresentar redução depois de 2010, e com intensificação da queda no período 20152018, quando se manifesta a crise político-econômica no país e há alteração na orientação da atuação do BNDES, devido à mudança de governo, em 2016.

\section{GRÁFICO 1}

Evolução dos desembolsos do BNDES para a indústria, em termos reais ${ }^{1,2}$

(Em R\$ milhões)

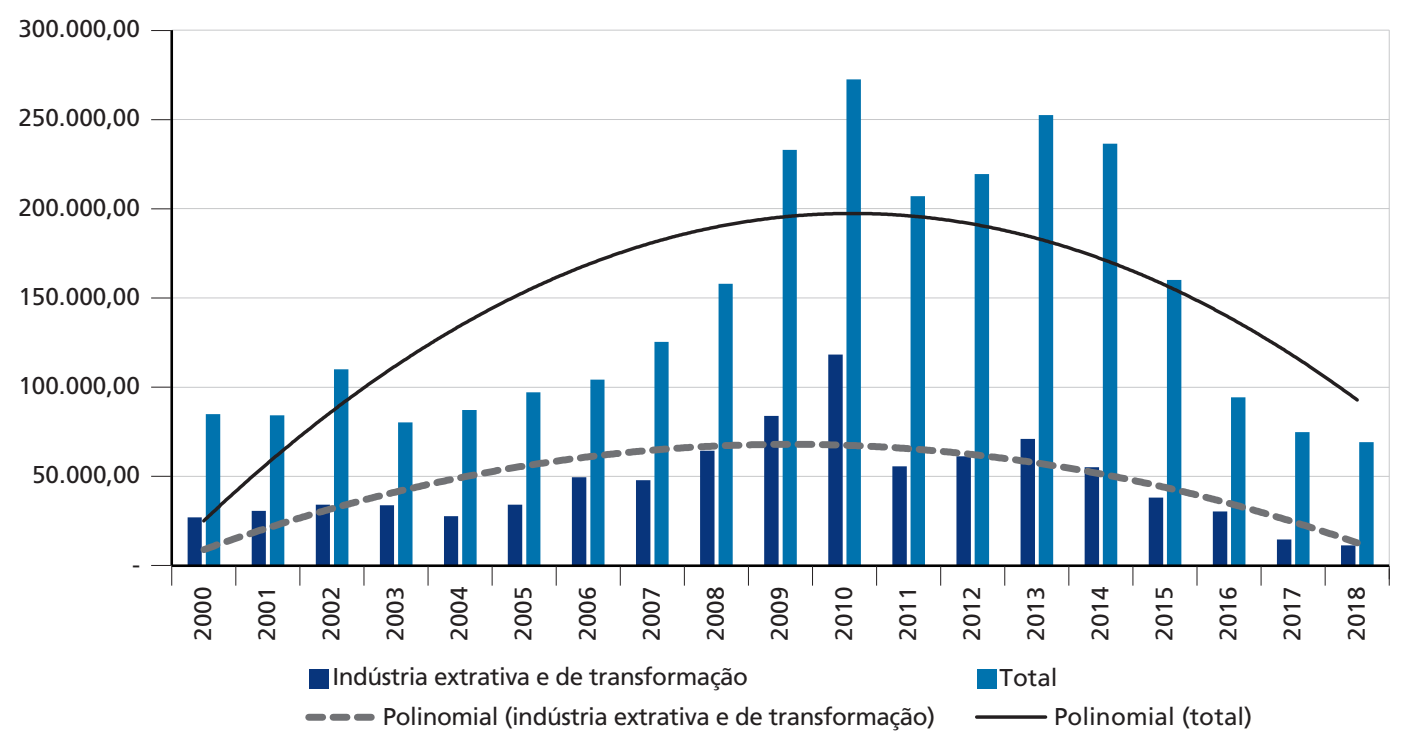

Fonte: BNDES (2019).

Elaboração dos autores.

Notas: 'Valores deflacionados pelo IGP-Disponibilidade Interna (DI), da FGV, a preços de 2018.

${ }^{2}$ Dados de desembolsos apenas de municípios especificados. 
No aspecto da alocação dos desembolsos no território brasileiro, na tabela 1 e na tabela 2, é possível observar que, entre 2000 e 2018, o Sudeste se destaca na absorçâo dos recursos, com $\mathrm{R} \$ 551,2$ bilhóes, cerca de $60,8 \%$ dos desembolsos. O financiamento na regiáo, no período relatado, esteve centrado, principalmente, na produção de outros equipamentos de transporte - embarcaçóes, aeronaves e motocicletas (10,8\%); veículos, reboque e carroceria (9,2\%); coque, petróleo e combustivel (8,2\%); produtos alimentícios (7,1\%); metalurgia (5,7\%); e máquinas e equipamentos (3,7\%), que juntos somavam mais de 73,5\% dos desembolsos do BNDES para a atividade industrial no Sudeste. Nessa regiáo os estados mais representativos na absorção dos desembolsos foram São Paulo (39,0\%) e Rio de Janeiro (11,7\%).

TABELA 1

Participação nos desembolsos do BNDES, do acumulado entre 2000 e 2018, segundo as regiões e as atividades industriais ${ }^{1}$ (Em \%)

\begin{tabular}{|c|c|c|c|c|c|c|}
\hline & Norte & Nordeste & Sudeste & Sul & Centro-Oeste & Brasil \\
\hline Bebidas & 0,0 & 0,3 & 0,5 & 0,3 & 0,1 & 1,2 \\
\hline Borracha e plástico & 0,1 & 0,4 & 1,6 & 0,8 & 0,1 & 2,9 \\
\hline Celulose e papel & 0,1 & 1,4 & 2,2 & 1,6 & 0,8 & 6,0 \\
\hline Confecção, vestuário e acessórios & 0,0 & 0,1 & 0,5 & 0,6 & 0,0 & 1,2 \\
\hline Coque, petróleo e combustível & 0,0 & 2,1 & 8,2 & 0,7 & 1,4 & 12,4 \\
\hline Couro, artefato e calçado & 0,0 & 0,3 & 0,3 & 0,5 & 0,0 & 1,2 \\
\hline Equipamentos de informática, eletrônico e ótico & 0,4 & 0,0 & 1,0 & 0,3 & 0,0 & 1,7 \\
\hline Farmoquímico e farmacêutico & 0,0 & 0,1 & 0,8 & 0,1 & 0,0 & 1,0 \\
\hline Fumo & 0,0 & 0,0 & 0,0 & 0,0 & 0,0 & 0,0 \\
\hline Gráfica & 0,0 & 0,0 & 0,1 & 0,1 & 0,0 & 0,2 \\
\hline Indústria extrativa & 1,2 & 0,6 & 1,6 & 0,3 & 0,3 & 4,0 \\
\hline Máquinas e equipamentos & 0,1 & 0,1 & 3,7 & 2,0 & 0,0 & 5,8 \\
\hline Madeira & 0,1 & 0,0 & 0,4 & 0,7 & 0,1 & 1,2 \\
\hline Manutenção, reparação e instal & 0,0 & 0,0 & 0,1 & 0,0 & 0,0 & 0,2 \\
\hline Máquinas e aparelhos elétricos & 0,0 & 0,1 & 0,9 & 1,3 & 0,0 & 2,4 \\
\hline Máquinas e equipamentos & 0,0 & 0,0 & 0,0 & 0,0 & 0,0 & 0,1 \\
\hline Metalurgia & 0,3 & 0,4 & 5,7 & 0,6 & 0,2 & 7,0 \\
\hline Mineral não metálico & 0,1 & 0,3 & 1,6 & 0,6 & 0,2 & 2,7 \\
\hline Móveis & 0,0 & 0,0 & 0,3 & 0,6 & 0,0 & 1,0 \\
\hline Outros equipamentos de transporte & 0,1 & 0,7 & 10,8 & 0,3 & 0,1 & 11,9 \\
\hline Produtos de metal & 0,0 & 0,1 & 1,0 & 0,8 & 0,1 & 2,0 \\
\hline Produtos alimentícios & 0,1 & 0,7 & 7,1 & 3,9 & 1,7 & 13,5 \\
\hline Produtos diversos & 0,0 & 0,0 & 0,3 & 0,1 & 0,0 & 0,4 \\
\hline Química & 0,0 & 1,8 & 2,2 & 0,6 & 0,3 & 5,0 \\
\hline Têxtil & 0,0 & 0,5 & 0,9 & 0,6 & 0,0 & 1,9 \\
\hline Veículos, reboques e carrocerias & 0,0 & 1,0 & 9,2 & 2,6 & 0,0 & 13,0 \\
\hline Total & 2,8 & 11,0 & 60,8 & 19,9 & 5,5 & 100 \\
\hline
\end{tabular}


Seguida pela região Sudeste está a região Sul, com 19,9\% do montante nacional, financiando principalmente as atividades de produtos alimentícios (3,9\%); veículos, reboque e carroceria (2,6\%); máquinas e equipamentos (2,0\%); e celulose e papel (1,6\%), que representavam $10,1 \%$ dos desembolsos para a indústria brasileira e 50,8\% do total destinado à região.

Por seu turno, as regióes alvo da política regional (Norte, Nordeste e Centro-Oeste), juntas, somavam cerca de 19,3\% do total dos desembolsos, valor inferior ao destinado a toda a região Sul. A região Nordeste foi a que mais absorveu recursos (11,0\%), cerca de $\mathrm{R} \$ 98,1$ bilhóes. O maior salto dos desembolsos no Nordeste foi entre 2000-2004 e 2005-2009, período em que, em meio à PDP, a participação saiu de $10,2 \%$ e chegou a $13,5 \%$ do total nacional, o que revela, em parte, o cumprimento do objetivo estabelecido na política. O financiamento, entre 2000 e 2018, esteve canalizado, principalmente, para a produção de coque, petróleo e combustivel $(2,1 \%)$, indústria quimica (1,8\%), celulose e papel $(1,4 \%)$ e veiculos, reboque e carroceria $(1,0 \%)$, que, somadas, representam 6,3\% dos desembolsos para a indústria brasileira e 57,3\% do total destinado a toda a regiáo. Os desembolsos para a regiáo se direcionaram, em grande medida, aos estados de Pernambuco (4,5\%), Bahia (3,5\%), Ceará (1,3\%) e Maranhão $(0,8 \%)$, que juntos detinham $91,8 \%$ dos recursos destinados à indústria da região.

TABELA 2

Total dos desembolsos para a indústria e participação relativa, em períodos selecionados ${ }^{1,2}$ - Brasil, regiões e UFs

\begin{tabular}{|c|c|c|c|c|c|c|c|c|}
\hline \multirow{2}{*}{ Regiões/UFs } & \multicolumn{4}{|c|}{$\begin{array}{l}\text { Desembolsos em termos absolutos } \\
\text { (R\$ milhões) }\end{array}$} & \multicolumn{4}{|c|}{$\begin{array}{l}\text { Desembolsos em termos relativos } \\
\qquad(\%)\end{array}$} \\
\hline & $\begin{array}{l}\text { De } 2000 \text { a } \\
2004\end{array}$ & $\begin{array}{l}\text { De } 2005 \text { a } \\
2009\end{array}$ & $\begin{array}{l}\text { De } 2010 \text { a } \\
2014\end{array}$ & $\begin{array}{l}\text { De } 2015 \text { a } \\
2018\end{array}$ & $\begin{array}{l}\text { De } 2000 \text { a } \\
2004\end{array}$ & $\begin{array}{l}\text { De } 2005 \text { a } \\
2009\end{array}$ & $\begin{array}{l}\text { De } 2010 \text { a } \\
2014\end{array}$ & $\begin{array}{l}\text { De } 2015 \text { a } \\
2018\end{array}$ \\
\hline Norte & $3.852,83$ & $7.955,55$ & $10.223,49$ & $2.598,64$ & 2,51 & 2,84 & 2,83 & 2,74 \\
\hline Rondônia & 161,99 & 352,46 & 691,99 & 81,37 & 0,11 & 0,13 & 0,19 & 0,09 \\
\hline Acre & 1,99 & 79,53 & 156,29 & 28,64 & 0,00 & 0,03 & 0,04 & 0,03 \\
\hline Amazonas & 899,79 & $2.370,02$ & $2.097,16$ & 218,81 & 0,59 & 0,85 & 0,58 & 0,23 \\
\hline Roraima & 0,45 & 1,61 & 36,48 & 8,74 & 0,00 & 0,00 & 0,01 & 0,01 \\
\hline Pará & $2.753,24$ & $4.845,62$ & $6.149,91$ & $2.130,18$ & 1,79 & 1,73 & 1,70 & 2,25 \\
\hline Amapá & 0,25 & 20,19 & 40,36 & 5,38 & 0,00 & 0,01 & 0,01 & 0,01 \\
\hline Tocantins & 35,13 & 286,13 & $1.051,29$ & 125,53 & 0,02 & 0,10 & 0,29 & 0,13 \\
\hline Nordeste & $15.640,00$ & $37.924,17$ & $33.641,17$ & $10.876,51$ & 10,17 & 13,54 & 9,30 & 11,47 \\
\hline Maranhão & 895,36 & $1.703,32$ & $4.383,72$ & 361,86 & 0,58 & 0,61 & 1,21 & 0,38 \\
\hline Piauí & 95,43 & 100,68 & 377,37 & 77,32 & 0,06 & 0,04 & 0,10 & 0,08 \\
\hline Ceará & $2.395,16$ & $1.835,98$ & $3.534,70$ & $3.476,57$ & 1,56 & 0,66 & 0,98 & 3,67 \\
\hline
\end{tabular}




\begin{tabular}{|c|c|c|c|c|c|c|c|c|}
\hline \multirow{2}{*}{ Regiões/UFs } & \multicolumn{4}{|c|}{$\begin{array}{l}\text { Desembolsos em termos absolutos } \\
\text { (R\$ milhões) }\end{array}$} & \multicolumn{4}{|c|}{$\begin{array}{l}\text { Desembolsos em termos relativos } \\
(\%)\end{array}$} \\
\hline & $\begin{array}{l}\text { De } 2000 \text { a } \\
2004\end{array}$ & $\begin{array}{l}\text { De } 2005 \text { a } \\
2009\end{array}$ & $\begin{array}{l}\text { De } 2010 \text { a } \\
2014\end{array}$ & $\begin{array}{l}\text { De } 2015 \text { a } \\
2018\end{array}$ & $\begin{array}{l}\text { De } 2000 \text { a } \\
2004\end{array}$ & $\begin{array}{l}\text { De } 2005 \text { a } \\
2009\end{array}$ & $\begin{array}{l}\text { De } 2010 \text { a } \\
2014\end{array}$ & $\begin{array}{c}\text { De } 2015 \text { a } \\
2018\end{array}$ \\
\hline Rio Grande do Norte & 216,32 & 285,90 & 670,00 & 112,91 & 0,14 & 0,10 & 0,19 & 0,12 \\
\hline Paraíba & 671,61 & 240,92 & 960,68 & 126,38 & 0,44 & 0,09 & 0,27 & 0,13 \\
\hline Pernambuco & 828,36 & $22.460,19$ & $12.096,35$ & $4.968,67$ & 0,54 & 8,02 & 3,34 & 5,24 \\
\hline Alagoas & 625,70 & 111,41 & $1.726,94$ & 105,85 & 0,41 & 0,04 & 0,48 & 0,11 \\
\hline Sergipe & 157,83 & 361,68 & 646,67 & 72,77 & 0,10 & 0,13 & 0,18 & 0,08 \\
\hline Bahia & $9.754,24$ & $10.824,08$ & $9.244,74$ & $1.574,18$ & 6,34 & 3,86 & 2,56 & 1,66 \\
\hline Sudeste & $102.832,73$ & $168.587,76$ & $217.405,08$ & $52.403,04$ & 66,87 & 60,20 & 60,11 & 55,27 \\
\hline Minas Gerais & $11.458,12$ & $20.980,42$ & $30.777,79$ & $10.528,72$ & 7,45 & 7,49 & 8,51 & 11,10 \\
\hline Espírito Santo & $4.706,29$ & $4.709,37$ & $6.284,49$ & 381,03 & 3,06 & 1,68 & 1,74 & 0,40 \\
\hline Rio de Janeiro & $8.840,92$ & $15.288,09$ & $71.379,61$ & $8.425,81$ & 5,75 & 5,46 & 19,74 & 8,89 \\
\hline São Paulo & $77.827,41$ & $127.609,88$ & $108.963,18$ & $33.067,47$ & 50,61 & 45,56 & 30,13 & 34,87 \\
\hline Sul & $28.541,19$ & $46.366,82$ & $78.365,96$ & $23.950,75$ & 18,56 & 16,56 & 21,67 & 25,26 \\
\hline Paraná & $6.700,78$ & $15.179,76$ & $23.831,97$ & $10.312,73$ & 4,36 & 5,42 & 6,59 & 10,88 \\
\hline Santa Catarina & $12.007,18$ & $11.402,98$ & $23.526,86$ & $7.002,83$ & 7,81 & 4,07 & 6,50 & 7,39 \\
\hline Rio Grande do Sul & $9.833,23$ & $19.784,07$ & $31.007,13$ & $6.635,19$ & 6,39 & 7,06 & 8,57 & 7,00 \\
\hline Centro-Oeste & $2.902,55$ & $19.228,86$ & $22.053,29$ & $4.990,01$ & 1,89 & 6,87 & 6,10 & 5,26 \\
\hline Mato Grosso do Sul & 264,13 & $4.454,99$ & $10.361,40$ & $2.731,43$ & 0,17 & 1,59 & 2,86 & 2,88 \\
\hline Mato Grosso & 697,75 & $3.062,34$ & $2.900,47$ & 468,45 & 0,45 & 1,09 & 0,80 & 0,49 \\
\hline Goiás & $1.845,17$ & $11.569,03$ & $8.375,88$ & $1.700,30$ & 1,20 & 4,13 & 2,32 & 1,79 \\
\hline Distrito Federal & 95,50 & 142,50 & 415,54 & 89,83 & 0,06 & 0,05 & 0,11 & 0,09 \\
\hline Total & $153.769,31$ & $280.063,16$ & $361.688,99$ & $94.818,96$ & 100 & 100 & 100 & 100 \\
\hline
\end{tabular}

$\mathrm{Na}$ sequência do Nordeste, está o Centro-Oeste (5,5\%), cujo montante foi destinado, em grande medida, à fabricação de produtos alimentícios $(1,7 \%)$, ao setor sucroalcooleiro contido nas atividades de coque, petróleo e combustivel $(1,4 \%)$ e celulose e papel $(0,8 \%)$, correspondendo a $70,9 \%$ do montante designado à regiáo. Os estados mais representativos na absorção dos recursos foram Goiás (2,63\%) e Mato Grosso do Sul (2,0\%), cujos desembolsos representam $84,2 \%$ do valor aplicado no Centro-Oeste. A região se destaca também pela sua evolução na parcela dos desembolsos, uma vez que sua participação no total dos desembolsos mais do que dobrou, saltando de 1,9\%, entre 2000-2004, para cerca de 6,9\%, entre 2005-2009, mantendo sua participação acima dos $5 \%$ ao longo dos períodos seguintes. 
Por fim, a região Norte, com 2,8\% do total dos desembolsos, destinados, em grande medida, às atividades da indústria extrativa $(1,2 \%)$, equipamentos de informática, eletrônicos e óptico (0,38\%) e metalurgia ( $0,29 \%)$, que juntos somavam $66,8 \%$ dos recursos destinados à região. Os estados que mais receberam financiamentos foram Pará (1,78\% do total do país) e Amazonas (0,63\%), cujos desembolsos representam, aproximadamente, $87,2 \%$ do valor aplicado na regiáo Norte.

Nesse período analisado, muito embora as regióes Sudeste e Sul detenham ainda a primazia no destino dos desembolsos, a ampliação dos desembolsos sobre as regióes alvo da política regional foi notória, sobretudo entre o primeiro período (2000-2004) e o segundo (2005-2009). Entre esses dois períodos, os desembolsos destinados ao Norte e ao Nordeste mais que dobraram, e os do Centro-Oeste quintuplicaram, ao passo que, no Sul e no Sudeste brasileiro, cresceram cerca de 60\%, favorecendo, por conseguinte, uma distribuição mais equânime entre as regiōes.

Entre o segundo período (2005-2009) e o terceiro (2010-2014), as regióes Sudeste e Sul apresentaram crescimento mais intenso: esta deteve um aumento de 69\% na captação de recursos pelo BNDES e aquela teve um crescimento de $29 \%$. Nas regiôes menos desenvolvidas, é possível observar o Norte, com aumento de $28,5 \%$ e, em menor escala, o Centro-Oeste, com $14,7 \%$. A região Nordeste, por contraste, apresentou decréscimo de 11,3\% no mesmo período.

Nesse sentido, no contexto posterior à crise internacional, a ampliação dos desembolsos ocorreu, de modo mais predominante, para as macrorregióes mais desenvolvidas. Tal resultado pode estar associado ao caráter industrial mais maduro e desenvolvido das regiōes Sul e Sudeste, que preservam, em grande medida, a maior parcela do país dos setores que atendem especificaçóes particulares do demandante e que aplicam diretamente a ciência em seus processos produtivos - caracterizados, portanto, por maior intensidade na relação capital-trabalho e maior sofisticação tecnológica em seus processos produtivos (Monteiro Neto e Silva, 2018) -, atividades estas que foram alvo da PSI, que visava ampliar a produção e a exportação de bens de capital e a inovação tecnológica.

Nota-se, grosso modo, que o BNDES, no decorrer dos anos 2000, ampliou sua atuação sobre a indústria brasileira, o que ganha relevância, pois ocorre num contexto de perda relativa da atividade industrial na produção nacional, conforme observado por Monteiro Neto e Silva (2018). Na ausência desta atuação do BNDES para financiar essas atividades, certamente os resultados poderiam ser agravados. Por seu turno, 
no seu ciclo mais intenso de crescimento dos desembolsos, a regiăo Sudeste perdeu participação no montante nacional, configurando uma desconcentração territorial, principalmente em relação aos estados do Sul e do Centro-Oeste do país. A região Sudeste, que historicamente deteve a maior parcela dos recursos, apresentou redução de 11,6 p.p. no total dos desembolsos entre o primeiro e último período. A regiáo Sul deteve um aumento de sua parcela de 6,7 p.p. A regiáo Centro-Oeste mais que dobrou sua participaçáo (de 1,9\% para 5,3\%). Esses processos apresentam novamente íntima relação com os resultados da evoluçáo do valor de transformaçáo industrial dessas regiōes, que revelam que a desconcentração da produção industrial se manifesta, com maior força, em direção às regióes Sul e Centro-Oeste (Monteiro Neto e Silva, 2018). Adicionalmente, os setores que nortearam, em maior escala, a atuação do BNDES no território nacional foram aqueles previstos nos programas para fortalecer a competitividade e consolidar e expandir a liderança da PDP, tais como a fabricação de produtos alimentícios; veículos, carrocerias e reboque; coque, petróleo e combustivel; outros equipamentos de transporte (que abrange a produção de embarcaçóes, aeronaves e motocicletas); metalurgia; e celulose e papel, que em conjunto respondem por $63,8 \%$ do total dos desembolsos para a indústria. Somente os setores de produtos alimentícios e coque, petróleo e combustivel receberam cerca de, $25,9 \%$ do total dos desembolsos entre 2000 e 2018. Tais setores compóem o grupo de atividades baseadas em recursos naturais, que, ao longo dos anos 2000 , apresentaram crescimento intenso de produção e produtividade, conforme o diagnóstico de padróes e ritmos da atividade industrial brasileira de Monteiro Neto e Silva (2018).

\section{TRAJETÓRIA DOS DESEMBOLSOS SOBRE A INDÚSTRIA NAS AGLOMERAÇÕES PRODUTIVAS RELEVANTES E POTENCIAIS}

Nesta seção são expostos os resultados referentes à evolução e à distribuição dos desembolsos do BNDES para a indústria (extrativa e de transformação) nas aglomeraçóes industriais relevantes (AIRs) e nas aglomeraçôes industriais potenciais (AIPs) entre os anos de 2000 e 2018. O objetivo é apresentar as trajetórias regionais de atuação do BNDES numa escala territorial menor, com ênfase no volume de recursos aplicados, no crescimento dos desembolsos e no tamanho do emprego industrial das microrregióes a que se destinam os recursos.

O conceito de AIRs no Brasil foi introduzido por Diniz e Crocco (1996), os quais enquadram nessa categoria as microrregióes homogêneas com mais de 10 mil empregos industriais. Por seu turno, as aglomeraçóes industriais de menor tamanho, aquelas 
com 5 mil e até 9.999 empregos industriais, já ganhavam atenção no estudo de Diniz (2013). Partindo destes conceitos, neste estudo são utilizadas as microrregióes geográficas por nível de emprego para analisar os padróes regionais de atuação do BNDES. As aglomerações industriais alvo da investigação são as AIRs (aquelas com mais de 10 mil empregos industriais) e as AIPs - estas divididas em dois grupos: tipo I (aglomeraçóes de 5 mil até 9.999 empregos industriais) e tipo II (aglomeraçóes industriais de mil até 4.999 empregos industriais). Para além dos dados de desembolsos e do IGP para a deflação dos resultados, foram utilizados os dados de emprego industrial da Rais.

A tabela 3 apresenta a distribuição dos desembolsos entre as aglomerações, além de ser possível observar a relevância das aglomeraçóes com mais de 10 mil empregos industriais como destino preferencial dos recursos em todas as regiôes - juntas as AIRs absorveram mais de $\mathrm{R} \$ 761,7$ bilhóes, que totalizam $83 \%$ de todos os desembolsos ao longo dos períodos analisados. O valor de desembolsos para essas AIRs passou de $\mathrm{R} \$ 130,2$ bilhóes - com média de $\mathrm{R} \$ 1$,3 bilhão para cada -, no período 2000-2004, para um total de $\mathrm{R} \$ 314,5$ bilhóes - com média de $\mathrm{R} \$ 2,1$ bilhóes por AIR -, período de ápice dos desembolsos (entre 2010 e 2014).

Ainda sobre a tabela 3, porém no âmbito macrorregional, é visível a concentração dos recursos nas aglomeraçóes do Sudeste, que preservam mais da metade do total dos recursos, sobretudo em suas AIRs. Contudo, apesar do número crescente de aglomeraçóes relevantes no Sudeste, a região vem perdendo paulatinamente a participação nos recursos destinados a ela, o que aponta para um processo de desconcentraçáo dos desembolsos para além das aglomeraçôes industriais mais consolidadas.

A segunda região com maior participação nos recursos, como visto na seção anterior, é o Sul do país. Diferentemente do Sudeste, a região em questão apresenta aumento na parcela dos desembolsos, guiados, principalmente, por suas AIRs. Em 2000, a região possuía 28 AIRs que recebiam recursos do BNDES, este número saltou para 34 em 2005; para 42 em 2010; e para 44 AIRs em 2015. Processo este acompanhado pela ampliação dos desembolsos: saltando de R $\$ 23,5$ bilhóes no período 2000-2004; alcançando $\mathrm{R} \$ 36,9$ bilhôes no período 2005-2009; e alcançando um total de $\mathrm{R} \$ 66,5$ bilhóes no auge da atuação do banco.

Muito embora a distribuição estrutural dos desembolsos para as aglomerações industriais tenha permanecido relativamente a mesma, condensado, principalmente nas AIRs e AIPs do tipo I das regióes Sudeste e Sul, há que se considerarem algumas nuances quando comparado o crescimento dos desembolsos nas outras regióes. 


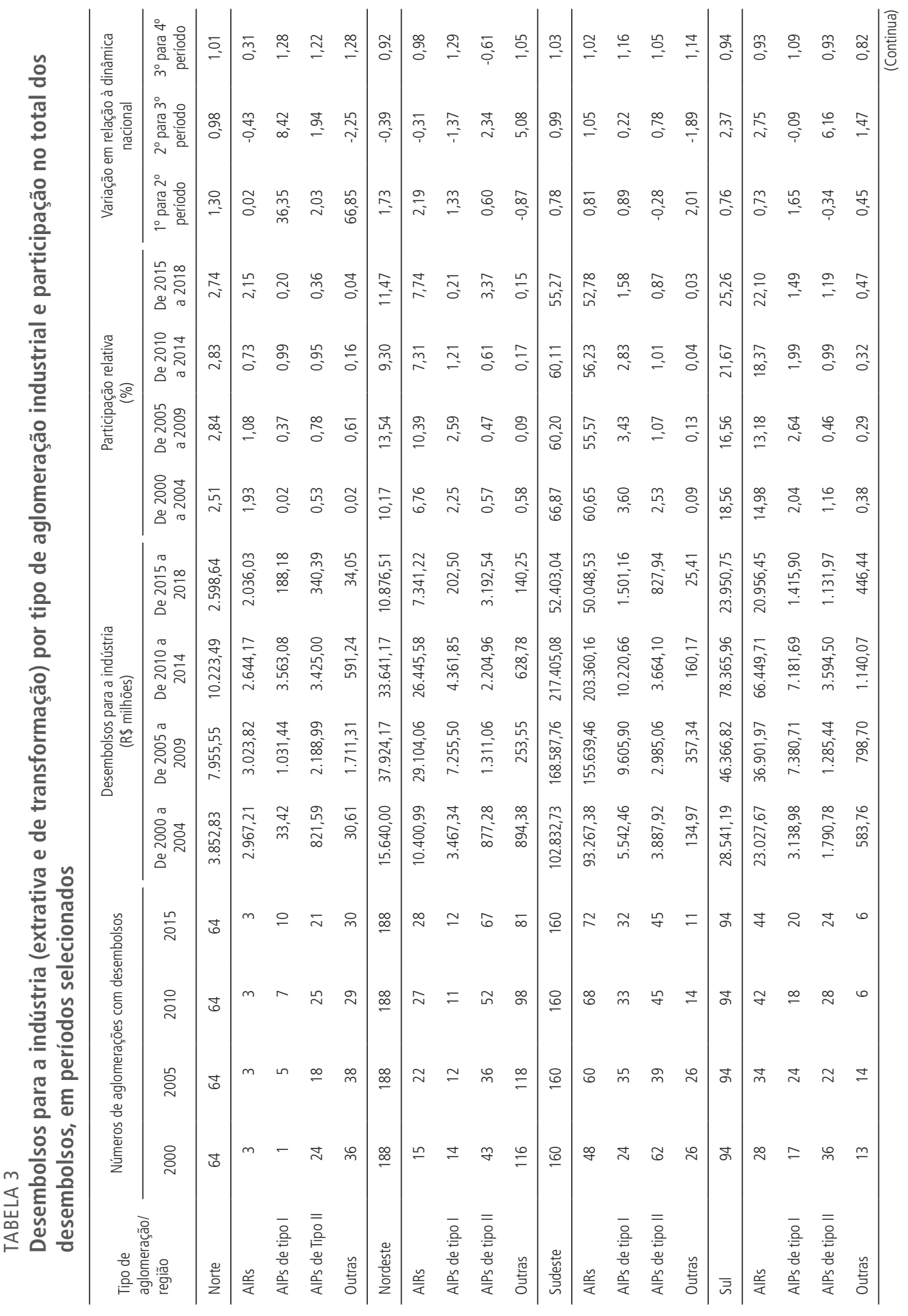




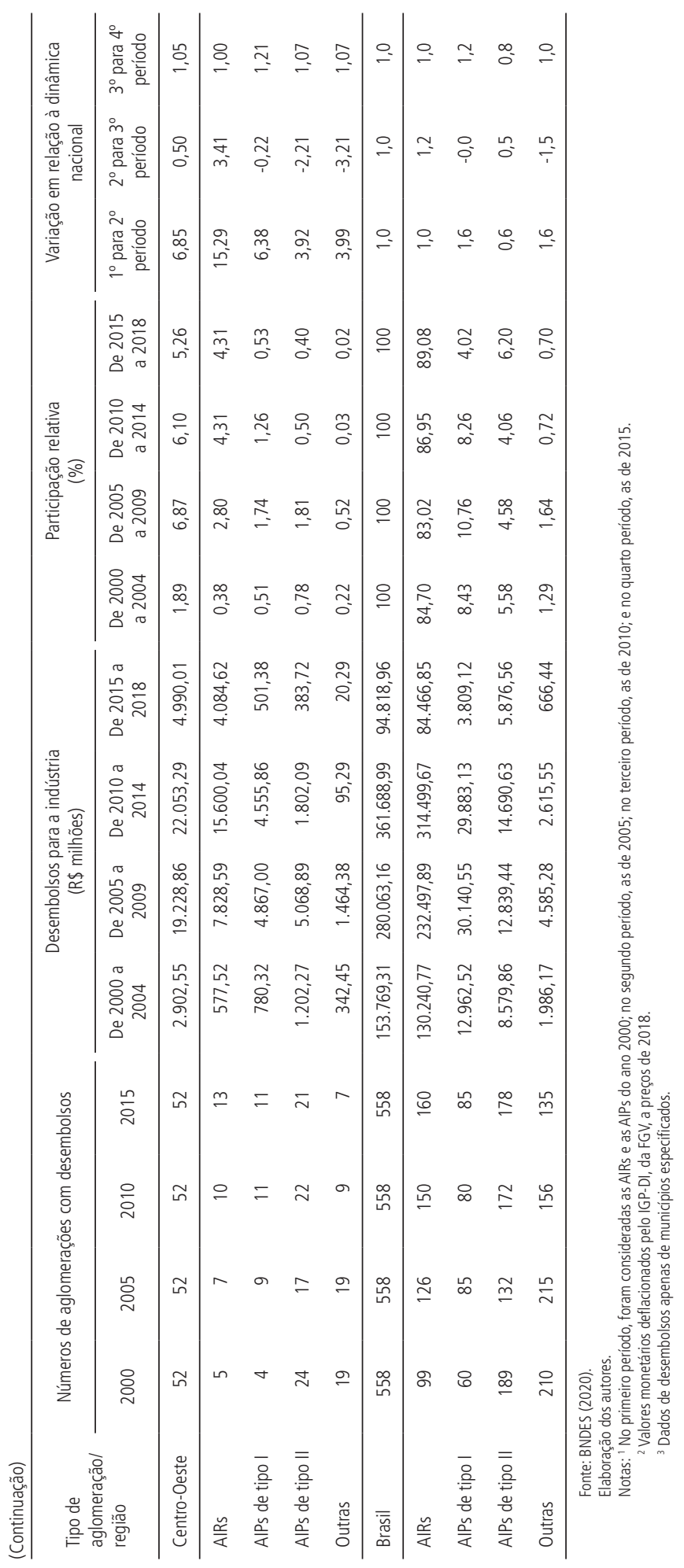

22 
Na região Norte, nos períodos 2000-2004 e 2005-2009, os principais agrupamentos beneficiados foram aqueles abaixo de 10 mil empregos industriais, com destaque para as AIPs do tipo II, cujos desembolsos ampliaram de R \$ 821,59 milhóes, entre 2000 e 2004, para R \$ 3,4 bilhóes, entre 2005-2009. Por seu turno, entre 2005-2009 e 2010-2014, os ganhos nas AIPs do tipo I sobressaem, saindo de aproximadamente R \$ 1 bilhão para cerca de R \$3,6 bilhôes.

Na região Nordeste, ao longo do período 2000-2018, as AIRs foram centrais na absorção dos recursos. No entanto, alteraçôes nos padróes no tempo merecem ser ressaltados. Nos períodos 2000-2004 e 2005-2009, as aglomeraçôes com mais de 5 mil empregos (AIRs e AIPs do tipo I) sobressaem, mais que dobram os recursos destinados a elas. $\mathrm{O}$ valor destinado às AIRs saltou de $\mathrm{R} \$ 10,4$ bilhôes para mais de 29,1 bilhôes, ao passo que o montante das AIPs do tipo I passou de $\mathrm{R} \$ 3,5$ bilhóes para mais de $\mathrm{R} \$ 7,2$ bilhôes.

No período subsequente, 2010-2014, a região apresentou queda nos desembolsos, centrados nas AIRs e nas AIPs do tipo I, enquanto as AIPs do tipo II e as aglomeraçóes abaixo de mil empregos industriais mantiveram a ampliaçáo nos desembolsos. $\mathrm{O}$ montante orientado às aglomeraçóes abaixo de mil empregos industriais mais que dobrou, passando de $\mathrm{R} \$ 253,55$ milhóes, entre 2005 e 2009, para $\mathrm{R} \$ 628,78$ milhóes, entre 2010 e 2015. Ao passo que os recursos destinados às AIPs do tipo II saíram de $R$ \$ 1,3 bilháo, entre 2005 e 2009, para $R$ \$ 2,2 bilhóes, entre 2010 e 2015, mantendo o crescimento no período, marcado pela redução da atuação do BNDES, chegando a mais de $\mathrm{R} \$ 3,1$ bilhóes entre 2015-2018.

Esse processo revela que no Nordeste, num primeiro momento, os desembolsos estiveram voltados para as aglomeraçóes industriais mais consolidadas; ${ }^{5}$ entretanto, nos períodos mais recentes, é possível notar um enfoque contínuo de ampliação da atuação do BNDES nas aglomeraçôes de menor porte, traduzindo uma novidade em termos regionais. Tais desembolsos para regiôes que dispóem de feição industrial mais rarefeita abrem a possibilidade de fortalecer arranjos produtivos, dinamizar a economia e alterar suas estruturas produtivas locais.

5. Centradas, principalmente, sobre as AIRs de capitais e seu entorno, como será detalhado mais adiante. 
Por fim, na região Centro-Oeste os principais agrupamentos beneficiados ao longo do período de crescimento de desembolsos do BNDES (2000-2014) foram as AIRs e as AIPs do tipo I. Nos períodos 2000-2004 e 2005-2009, as AIRs da regiáo foram as que mais apresentaram crescimento: o montante dos desembolsos saltou de R \$ 577,52 milhões para mais de R \$ 7,8 bilhóes, atingindo a marca de $\mathrm{R}$ \$ 15,6 bilhôes entre 2010 e 2014. Enquanto o montante de suas AIPs do tipo I passou de R \$ 780,32 milhóes, entre 2000 e 2004, para R \$ 4,8 bilhóes, entre 2005 e 2009, mantendo-se em patamar elevando entre 2010 e 2014, com R \$ 4,5 bilhóes. O crescimento dos desembolsos foi acompanhado de acréscimo no número de microrregióes pertencentes a esses grupos. Entre 2000 e 2018, o contingente de AIRs e AIPs do tipo I mais que dobrou, ao passo que as aglomeraçóes com menos de mil empregos industriais reduziram para abaixo da metade. Essa mudança pode ser reflexo dos desembolsos, no período inicial, para as AIPs (tipos I e II) e as aglomerações com menos de mil empregos industriais. Essa ação contribui para o fortalecimento e a consolidação de estruturas industriais, que, por conseguinte, ampliam o nível de emprego das microrregióes, impactando a percepção do montante dos desembolsos para a camada acima de 5 mil empregos industriais.

No que concerne à localização dessas aglomerações, aquelas com grandes volumes de desembolsos são poucas e distribuídas, predominantemente, na área do "polígono" do desenvolvimento industrial. ${ }^{6}$ Estas também tenderam a permanecer as mesmas no período analisado, muito embora mudanças mais ou menos pontuais sejam verificáveis, como os investimentos em nova áreas, como: i) na expansão dos desembolsos no entorno do "polígono", sobretudo no Sul, no vetor Rio-Vitória e Centro-Oeste; e ii) em algumas operaçóes no Norte e Nordeste. De modo geral, configura-se um padrão de atuação, com grandes investimentos em três eixos: i) Sul-Sudeste e seu transbordo; ii) as principais capitais e regiôes em seu entorno; e iii) a faixa litorânea do Nordeste (mapa 1).

6. Segundo Diniz e Crocco (1996), a área do "polígono" é formada pelas regiões que vão do centro de Minas Gerais até o nordeste do Rio Grande do Sul, abarcando a parte sul do estado de Minas Gerais e o Triângulo Mineiro; o interior do estado de São Paulo, com destaque para as regiões do Vale do Paraíba Paulista (São José dos Campos e arredores) e a região de Campinas (o que inclui as cidades de Piracicaba, Limeira e Americana) e o centro do estado, englobando Ribeirão Preto e São Carlos); englobando as regiões de Curitiba, Maringá e Londrina, no estado do Paraná; Florianópolis e Oeste Catarinense, no estado de Santa Catarina; o norte do estado do Rio Grande do Sul (Caxias do Sul); e a RM de Porto Alegre. 
No eixo Sul-Sudeste sobressaem nos grupos de volume de desembolsos médios a muito altos, nos diferentes períodos analisados, as aglomerações:

- da RM de São Paulo e seu entorno, marcadas pelas AIRs de São Paulo (SP), São José dos Campos (SP), Campinas (SP), Osasco (SP), Santos (SP) e Sorocaba (SP);

- da RM de Belo Horizonte e proximidades, nas quais se enquadram as AIRs de Belo Horizonte (MG), Ipatinga (MG), Itabira (AIR a partir de 2005) e Conselheiro Lafaiete (MG) - AIR a partir de 2010;

- no Sul, onde se destacam as aglomerações do "polígono", como Curitiba (PR), Joinville (SC), Blumenau (SC), Concórdia (SC), Chapecó (SC), Porto Alegre (RS), Montenegro (RS) e Caxias do Sul (RS), e sobressai também a expansão para Telêmaco Borba (PR) - AIR a partir de 2015; e

- da expansão do "polígono", no vetor Rio de Janeiro-Vitória, com as AIRs do Vale do Paraíba Fluminense (RJ), Rio de Janeiro (RJ), Vitória (ES) e Linhares (ES) - AIR a partir de 2005 -, no primeiro caso vinculado à construção do polo metalomecânico, com base em investimentos na indústria automobilística de Resende e Porto Real, e nos demais projetos da faixa litorânea associados ao setor do petróleo, gás e combustíveis fósseis (Siqueira e Brandáo, 2014).

Adicionalmente, a tabela 4, ao mostrar o volume de recursos nas trinta principais aglomeraçóes nos períodos 2000-2004, 2005-2009, 2010-2014 e 2015-2018, explicita a centralidade do eixo Sul-Sudeste e seu transbordo como demandantes de recursos. Os dados nela reportados revelam, de modo geral, que essas microrregiōes, em conjunto com as trinta maiores, detêm mais de $56 \%$ do total dos desembolsos e estáo localizadas, predominantemente, na área do "polígono" de Diniz e Crocco (1996) e sua extensão para Rio de Janeiro (RJ), Vale do Paraíba Fluminense (RJ), Ipatinga (MG), Vitória (ES) e Linhares (ES). 
MAPA 1

Aglomerações industriais do Brasil: desembolsos do BNDES para a indústria (extrativa e de transformação) em períodos selecionados ${ }^{1,2,3,4}$

1 A - Período 2000-2004

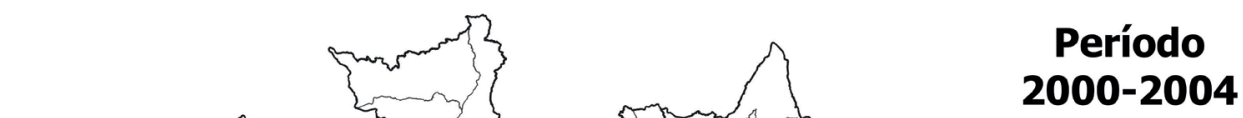

\section{Desembolsos (em R\$)}

- 145.493 - 272.378.709 [288]

- $272.378 .709-896.426 .722$ [28]

- 896.426.722 - 2.588.070.814 [16]

- 2.588.070.814- 7.069.230.729 [7]

- 7.069.230.729 - 30.847.759.770 [2]

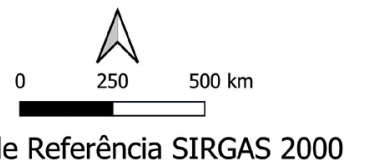


1B - Período 2005-2009

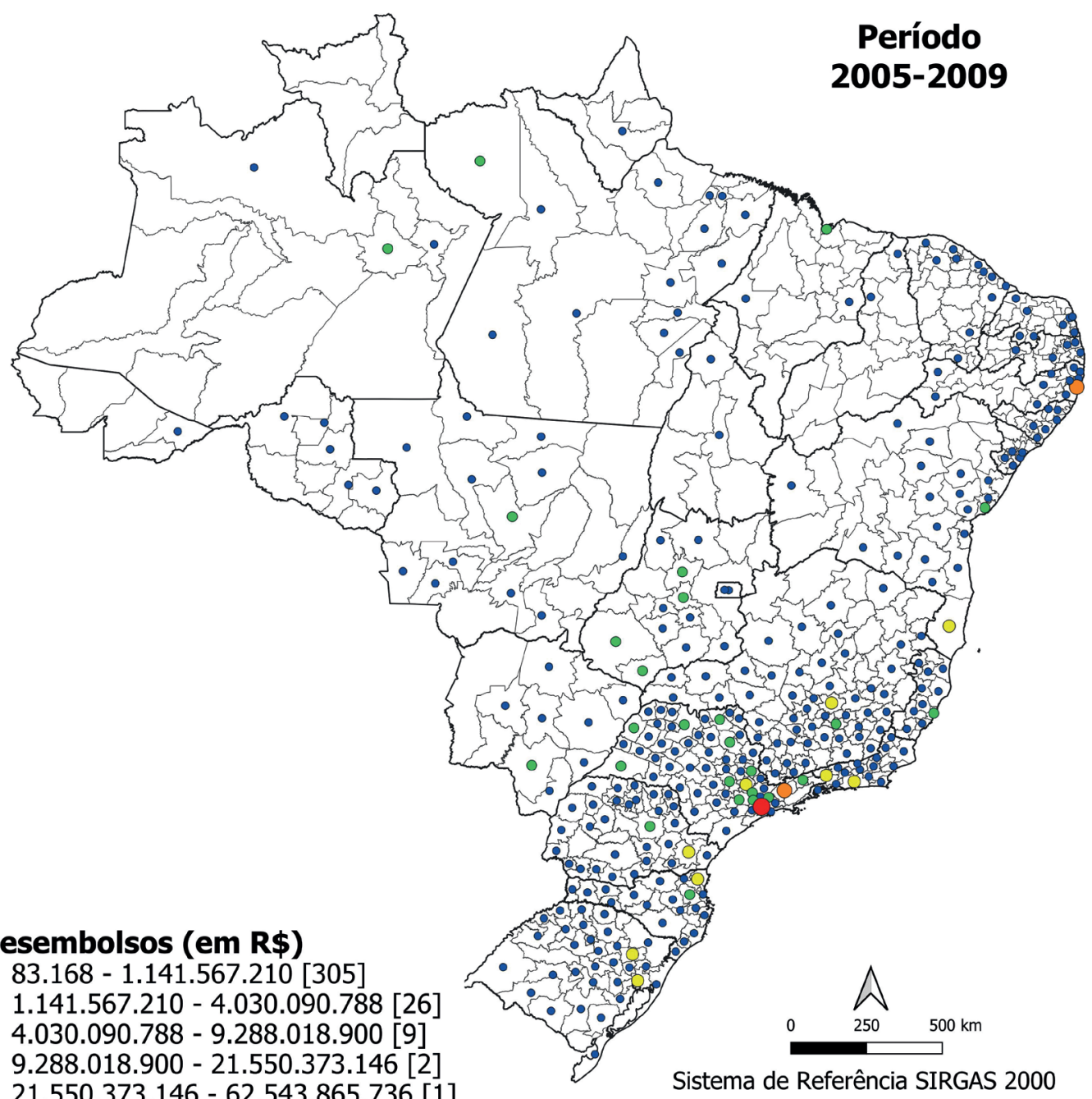

- 83.168 - 1.141.567.210 [305]

- $1.141 .567 .210-4.030 .090 .788$ [26]

- 4.030.090.788 - 9.288.018.900 [9]

$9.288 .018 .900-21.550 .373 .146[2]$

Sistema de Referência SIRGAS 2000 


\footnotetext{
$1 C$ - Período 2010-2014
}

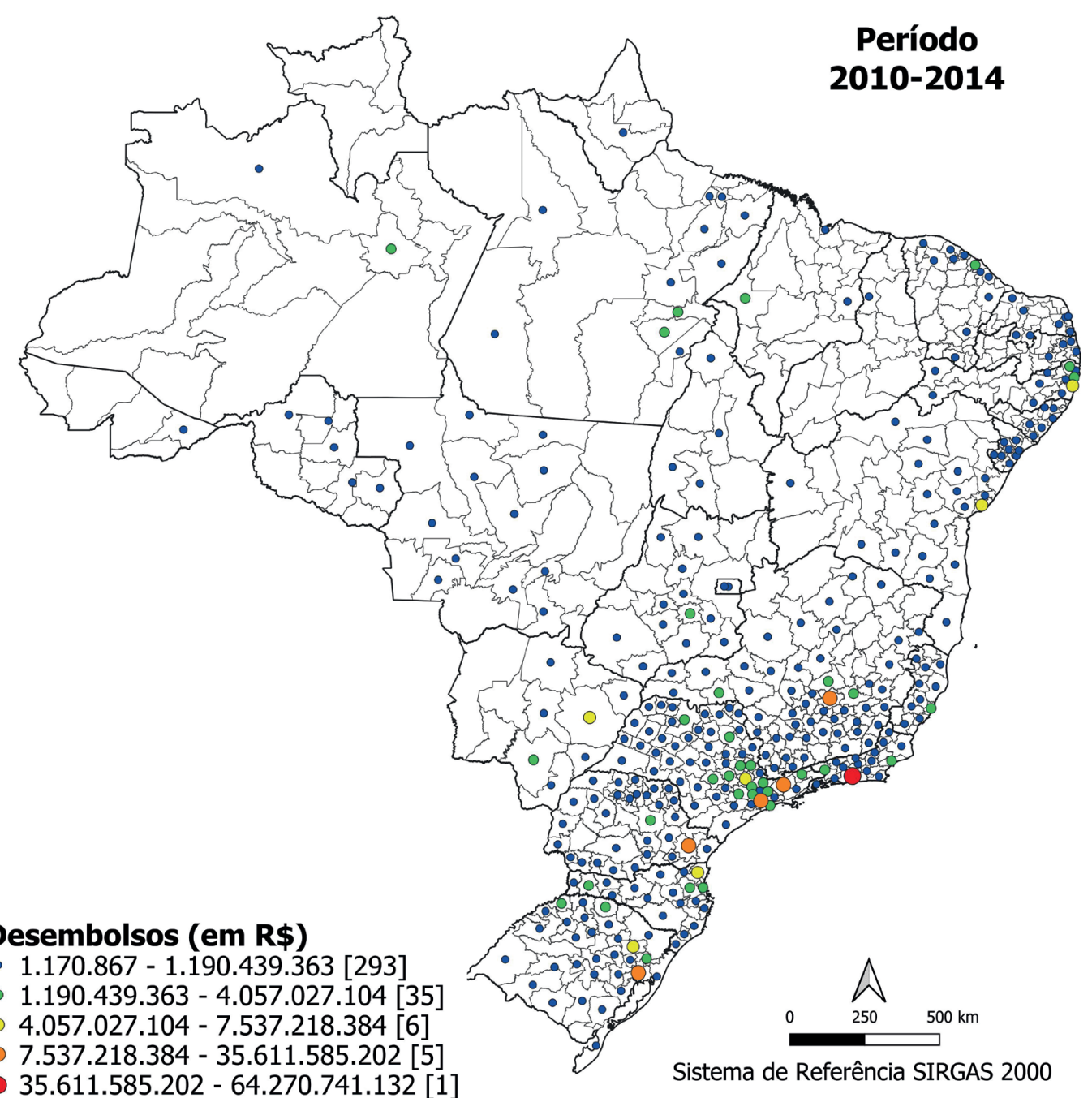




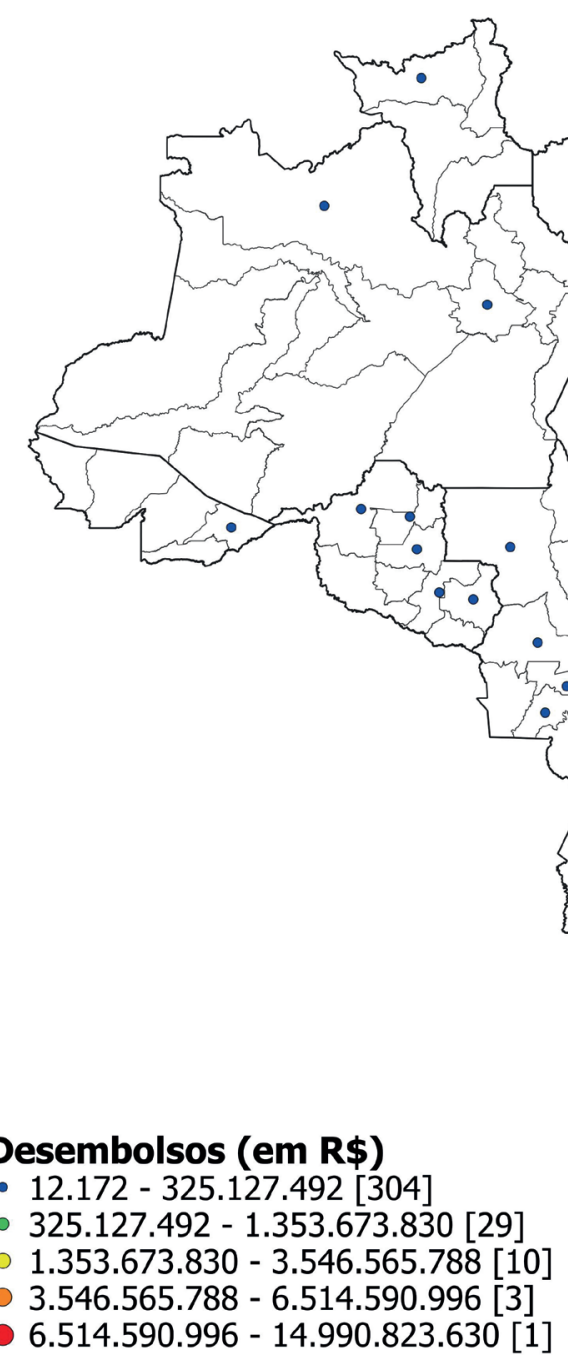

\section{Período 2015-2018}

Desembolsos (em R\$)

- 12.172 - 325.127 .492 [304]

- $325.127 .492-1.353 .673 .830[29]$

- $1.353 .673 .830-3.546 .565 .788[10]$

3.546.565.788 - 6.514.590.996 [3]

- 6.514.590.996 - 14.990.823.630 [1]

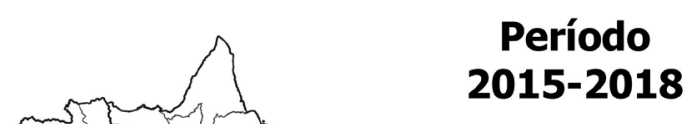

Fonte: BNDES (2020).

Elaboração dos autores.

Notas: ${ }^{1}$ No primeiro período, foram consideradas as AIRs e as AIPs do ano 2000; no segundo período, as de 2005; no terceiro período, as de 2010; e no quarto período, as de 2015.

${ }^{2}$ Valores monetários deflacionados pelo IGP-DI, da FGV, a preços de 2018.

${ }^{3}$ Dados de desembolsos apenas de municípios especificados.

${ }^{4}$ Grupos formados por quebra natural de Jenks (1977).?

Obs.: Os valores entre colchetes referem-se à contagem de número de aglomerações em cada grupo.

7. 0 método ajusta os limites das classes de acordo com a distribuição dos dados, identificando pontos de quebra por meio de uma análise estatística que se baseia na variabilidade das informações, o que minimiza a soma da variância em cada uma das classes. 
TABELA 4

Total dos desembolsos e posição das trinta principais AIRs na absorção de recursos, em períodos selecionados ${ }^{1,2}$

(Em R\$ milhões)

\begin{tabular}{|c|c|c|c|c|c|c|c|c|}
\hline \multirow{2}{*}{ Posição } & \multicolumn{2}{|c|}{ De 2000 a 2004} & \multicolumn{2}{|c|}{ De 2005 a 2009} & \multicolumn{2}{|c|}{ De 2010 a 2014} & \multicolumn{2}{|c|}{ De 2015 a 2018} \\
\hline & $\begin{array}{l}\text { Aglomeração } \\
\text { industrial }\end{array}$ & Total & $\begin{array}{l}\text { Aglomeração } \\
\text { industrial }\end{array}$ & Total & $\begin{array}{l}\text { Aglomeração } \\
\text { industrial }\end{array}$ & Total & $\begin{array}{c}\text { Aglomeração } \\
\text { industrial }\end{array}$ & Total \\
\hline 1 & $\begin{array}{l}\text { São José dos } \\
\text { Campos }\end{array}$ & $30.847,76$ & São Paulo & $62.543,87$ & Rio de Janeiro & $64.270,74$ & $\begin{array}{l}\text { São José dos } \\
\text { Campos }\end{array}$ & $14.990,82$ \\
\hline 2 & São Paulo & $29.858,79$ & $\begin{array}{l}\text { São José dos } \\
\text { Campos }\end{array}$ & $21.550,37$ & São Paulo & $35.611,59$ & Rio de Janeiro & $6.514,59$ \\
\hline 3 & Salvador & $7.069,23$ & Suape & $21.350,75$ & $\begin{array}{l}\text { São José dos } \\
\text { Campos }\end{array}$ & $16.447,68$ & São Paulo & $6.143,78$ \\
\hline 4 & $\begin{array}{l}\text { Vale do Paraíba } \\
\text { Fluminense }\end{array}$ & $4.254,10$ & Rio de Janeiro & $9.288,02$ & Belo Horizonte & $11.152,68$ & Belo Horizonte & $4.678,65$ \\
\hline 5 & Rio de Janeiro & $4.233,84$ & Belo Horizonte & $9.004,32$ & Curitiba & $10.600,31$ & $\begin{array}{l}\text { Telêmaco } \\
\text { Borba }\end{array}$ & $3.546,57$ \\
\hline 6 & Belo Horizonte & $4.051,14$ & Curitiba & $6.643,02$ & Porto Alegre & $10.138,58$ & Baixo Curu & $2.805,06$ \\
\hline 7 & Curitiba & $3.849,47$ & Porto Alegre & $6.370,96$ & Caxias do Sul & $7.537,22$ & Campinas & $2.721,24$ \\
\hline 8 & Joinville & $3.678,32$ & Caxias do Sul & $6.286,07$ & Campinas & $7.471,87$ & Curitiba & $2.419,95$ \\
\hline 9 & Porto Alegre & $3.599,70$ & Joinville & $5.261,11$ & Salvador & $6.983,17$ & Suape & $2.414,49$ \\
\hline 10 & Caxias do Sul & $2.588,07$ & Porto Seguro & $5.187,78$ & Três Lagoas & $6.980,30$ & Porto Alegre & $2.075,12$ \\
\hline 11 & Campinas & $2.461,59$ & $\begin{array}{l}\text { Vale do Paraíba } \\
\text { Fluminense }\end{array}$ & $5.167,01$ & Suape & $6.798,35$ & Três Lagoas & $2.071,44$ \\
\hline 12 & Linhares & $2.363,30$ & Campinas & $4.278,55$ & Joinville & $6.637,33$ & $\begin{array}{l}\text { Mata } \\
\text { Setentrional } \\
\text { Pernambucana }\end{array}$ & $1.839,41$ \\
\hline 13 & Concórdia & $2.297,06$ & Salvador & $4.030,09$ & Blumenau & $4.057,03$ & Itabira & $1.805,68$ \\
\hline 14 & Vitória & $2.144,15$ & Vitória & $3.591,02$ & Vitória & $4.016,17$ & Parauapebas & $1.700,65$ \\
\hline 15 & Ipatinga & $2.067,68$ & Sorocaba & $3.366,20$ & Sorocaba & $3.856,08$ & Caxias do Sul & $1.353,67$ \\
\hline 16 & Belém & $2.046,49$ & $\begin{array}{l}\text { Telêmaco } \\
\text { Borba }\end{array}$ & $3.185,51$ & Imperatriz & $3.108,09$ & Itajaí & $1.300,09$ \\
\hline 17 & Porto Seguro & $1.875,52$ & $\begin{array}{l}\text { Conselheiro } \\
\text { Lafaiete }\end{array}$ & $2.930,76$ & Marabá & $2.876,19$ & Joinville & $1.263,73$ \\
\hline 18 & Fortaleza & $1.788,18$ & $\begin{array}{l}\text { Sudoeste de } \\
\text { Goiás }\end{array}$ & $2.902,46$ & Botucatu & $2.833,42$ & Florianópolis & $1.083,04$ \\
\hline 19 & Sorocaba & $1.650,74$ & Moji Mirim & $2.509,53$ & $\begin{array}{l}\text { Mata Setentrio- } \\
\text { nal Pernambu- } \\
\text { cana }\end{array}$ & $2.829,49$ & Salvador & $1.041,89$ \\
\hline 20 & Santos & $1.623,36$ & Manaus & $2.357,81$ & Jundiaí & $2.687,07$ & $\begin{array}{l}\text { Vale do Paraíba } \\
\text { Fluminense }\end{array}$ & 901,64 \\
\hline 21 & Chapecó & $1.394,36$ & Piracicaba & $2.339,31$ & Guarulhos & $2.612,25$ & Blumenau & 731,49 \\
\hline 22 & Blumenau & $1.277,78$ & Guarulhos & $2.320,79$ & Itabira & $2.411,52$ & Osasco & 701,75 \\
\hline 23 & Montenegro & $1.250,70$ & Guaratinguetá & $2.252,06$ & Itajaí & $2.402,78$ & Ribeirão Preto & 700,58 \\
\hline 24 & $\begin{array}{l}\text { Conselheiro } \\
\text { Lafaiete }\end{array}$ & $1.248,48$ & Anápolis & $2.146,35$ & Osasco & $2.330,49$ & Chapecó & 682,56 \\
\hline 25 & Osasco & $1.219,14$ & Ceres & $2.085,21$ & Goiânia & $2.269,82$ & Maringá & 659,41 \\
\hline
\end{tabular}




\begin{tabular}{|c|c|c|c|c|c|c|c|c|}
\hline \multirow[b]{2}{*}{ Posição } & \multicolumn{2}{|c|}{ De 2000 a 2004} & \multicolumn{2}{|c|}{ De 2005 a 2009} & \multicolumn{2}{|c|}{ De 2010 a 2014} & \multicolumn{2}{|c|}{ De 2015 a 2018} \\
\hline & $\begin{array}{l}\text { Aglomeração } \\
\text { industrial }\end{array}$ & Total & $\begin{array}{l}\text { Aglomeração } \\
\text { industrial }\end{array}$ & Total & $\begin{array}{l}\text { Aglomeração } \\
\text { industrial }\end{array}$ & Total & $\begin{array}{l}\text { Aglomeração } \\
\text { industrial }\end{array}$ & Total \\
\hline 26 & Manaus & 896,43 & Dourados & $2.079,14$ & Macaé & $2.234,75$ & Macaé & 636,32 \\
\hline 27 & Itajaí & 852,62 & Osasco & $1.878,70$ & Ribeirão Preto & $2.209,85$ & Sorocaba & 623,05 \\
\hline 28 & Guarulhos & 822,90 & Jundiaí & $1.853,37$ & Santos & $2.152,53$ & $\begin{array}{l}\text { Itapecerica da } \\
\text { Serra }\end{array}$ & 578,01 \\
\hline 29 & Andradina & 788,60 & Ribeirão Preto & $1.845,73$ & Fortaleza & $2.093,19$ & $\begin{array}{l}\text { Bragança } \\
\text { Paulista }\end{array}$ & 484,25 \\
\hline 30 & $\begin{array}{l}\text { Aglomeração } \\
\text { urbana de São } \\
\text { Luís }\end{array}$ & 724,69 & Alto Teles Pires & $1.781,73$ & $\begin{array}{l}\text { Vale do Paraíba } \\
\text { Fluminense }\end{array}$ & $2.078,99$ & Guarulhos & 451,54 \\
\hline \multicolumn{2}{|c|}{ Total das trinta principais } & $124.824,18$ & & $208.387,58$ & & $239.689,51$ & & $68.920,45$ \\
\hline \multicolumn{2}{|c|}{$\begin{array}{l}\text { Total dos desembolsos para } \\
\text { a indústria }\end{array}$} & $153.769,31$ & & $280.063,16$ & & $361.688,99$ & & $94.818,96$ \\
\hline
\end{tabular}

Para além do eixo Sul-Sudeste e seu transbordo, existem algumas aglomeraçôes que se destacam. No que concerne à regiáo Nordeste, os maiores desembolsos estão localizados na faixa litorânea, nas proximidades das capitais dos estados do Ceará, de Pernambuco, da Bahia e do Maranhão.

No Ceará, para a microrregiâo de Fortaleza (CE), foram destinados R $\$ 5,0$ bilhóes, a maior parcela para a indústria tradicional, $34,6 \%$ dos recursos guiados para a produçáo de alimentos e bebidas e 30,0\% para a induistria têxtil. Seguida desta, no mesmo estado, está a aglomeração de Baixo Curu (CE), com mais de R \$ 2,8 bilhôes, dos quais $94,9 \%$ estiveram voltados para a metalurgia. Certamente, tais investimentos devem estar associados à Companhia Siderúrgica do Pecém (CSP), que iniciou suas operações em 2016 (CSP, 2020) e detinha previsão de produção de 3 milhōes de toneladas de placas de aço ao ano em sua primeira fase (BNDES, 2015). Desde sua inauguração, a CSP opera em Zona de Processamento de Exportação (ZPE) e utiliza o Terminal Portuário de Pecém ${ }^{8}$ para receber o minério da Vale, o carvão metalúrgico importado e as placas de aço exportadas.

8. 0 Porto de Pecém foi inaugurado em 2002, e desde o início de suas operações, além das cargas do próprio estado, o porto atende às demandas de escoamento da produção de estados vizinhos, como Maranhão, Piauí, Rio Grande do Norte, Paraíba, Pernambuco e Bahia. Desses dois últimos, atende especialmente à região fruticultora do vale do rio São Francisco (Petrolina/Juazeiro). 
Já no estado de Pernambuco, a AIR da capital, Recife (PE), absorveu no período $\mathrm{R} \$ 2,9$ bilhóes, dos quais 38,7\% foram designados à produção de alimentos e bebidas $\mathrm{e}$ 13,4\%, para a atividade de borracha e plástico. Assim como no Ceará, o destino preferencial dos desembolsos em Pernambuco esteve direcionado às aglomeraçóes próximas à regiâo metropolitana, onde se destacam as aglomeraçôes de Suape (PE) e Mata Setentrional Pernambucana (PE), com investimentos para além dos setores da indústria tradicional.

Somente a aglomeração de Suape (PE) absorveu mais de R \$ 30,6 bilhôes, 55,1\% deles voltados para a produção de coque, petróleo e combustivel, 17\% voltados à indústria quimica e 19,6\%, para a atividade de outros equipamentos de transporte. Nos dois primeiros casos, os desembolsos são reflexo do projeto do Complexo Petroquímico de Suape - com o objetivo de estruturar um novo polo petroquímico de poliéster, integrado à cadeia nacional têxtil e de embalagens de politereftalato de etileno (Bacellar e Nali, 2014a). No último, os investimentos refletem os esforços sobre o Estaleiro Atlântico Sul, localizado no Complexo Industrial do Porto de Suape, que dispóe de capacidade de construção de embarcações de grande porte, plataformas e estruturas flutuantes, bem como de realizar conversóes para o setor de petróleo offshore (Bacellar e Nali, 2014a).

Em menor escala, a Mata Setentrional Pernambucana (PE) deteve no período R \$ 4,8 bilhôes, voltados, principalmente, para a produção de veículos, reboque e carroceria $(83,9 \%)$, resultado de projetos ligados à fábrica da Fiat/Jeep, para a implantação de uma nova unidade de produção de automóveis, a elaboração de uma nova família de veículos e de um novo motor global, a construção de uma fábrica de motores, a construçáo de um campo de provas e a estruturaçáo de um parque de fornecedores ao redor da fábrica (Neves et al., 2014).

No estado da Bahia, a maior notoriedade está na AIR de Salvador (BA), com $\mathrm{R} \$ 19,1$ bilhóes, dos quais 50,6\% foram para a indústria química e 23,3\%, para a produção de veículos, reboque e carroceria. Tais composições retratam a força atrativa do Polo Industrial de Camaçari e do Centro Industrial de Aratu, que juntos englobam o maior polo petroquímico do país e outras atividades, tais como a indústria química de fertilizantes, solventes, automobilística e de pneumáticos (Bacellar e Nali, 2014a). Para além da RM de Salvador, se destaca, no litoral sul baiano, a AIR de Porto Seguro (BA), com R \$ 7,4 bilhôes, 96,5\% deles voltados para a produção de celulose e papel.

No estado do Maranhão, o maior volume de desembolsos foi para a microrregiáo da capital, Aglomeração Urbana de São Luís (MA), com mais de R \$ 3,6 bilhôes, 79,8\% deles destinados à indústria extrativa. Seguida desta está a aglomeração de Imperatriz 
(MA), com R \$ 3,2 bilhões, voltados, principalmente, para a produção de celulose e papel (94,3\%), reflexo da construçáo de uma nova unidade industrial da Suzano para a produção de celulose de eucalipto, com capacidade inicial de produção de 1,4 milhão de toneladas/ano (Bacellar e Nali, 2014a).

$\mathrm{Na}$ região Norte as aglomerações industriais que mais sobressaem são as dos estados do Pará e Amazonas. No caso do Pará, os desembolsos estiveram relacionados, em grande medida, à indústria extrativa mineral e às atividades de processamento industrial relacionados a ela. Esses são os casos de Marabá (PA), com cerca de $\mathrm{R} \$ 3,7$ bilhôes, destinados, principalmente, à indústria extrativa $(68,8 \%)$ e à metalurgia (18,6\%); a aglomeração da capital, Belém, com R \$ 3,3 bilhôes, dos quais 56,3\% destinados à metalurgia e 11,7\%, à indústria extrativa; Parauapebas (PA), com mais de $\mathrm{R}$ \$ 3,0 bilhôes, 98,5\% voltados para a indústria extrativa; e Óbidos (PA), com R \$2,7 bilhôes, orientados, em grande medida, à indústria extrativa (87,6\%). Por seu turno, no estado do Amazonas se destaca a microrregiáo da capital, Manaus (AM), com R \$ 5,5 bilhôes, dos quais $60,6 \%$ foram para equipamentos de informática, eletrônico e ótico e 6,5\%, para as atividades de produção borracha e plástico. A participaçáo elevada do setor de eletrônicos na região deve-se à situação especial de incentivos fiscais da Zona Franca de Manaus.

No Centro-Oeste, entre 2000 e 2018, houve um conjunto de empreendimentos, sobretudo nas aglomerações do estado de Goiás. Esses foram os casos das aglomeraçôes de Sudoeste de Goiás (GO), com aproximadamente R \$ 4,8 bilhôes, 74,2\% para coque, petróleo e combustivel - vinculados à cadeia sucroenergética e de biocombustíveis (Milanez et al., 2014) - e 23,0\% para produçáo alimentícios e bebidas; Ceres (GO), com $\mathrm{R} \$ 3,5$ bilhôes, $65,5 \%$ destinado à indústria extrativa e 23,4\%, à produção de alimentos; Anápolis (GO), com $\mathrm{R} \$ 3,1$ bilhóes, dois quais 73,4\% designados para a produçáo de alimentos e 7,3\%, para a atividade farmacêutica e farmoquimica; e Goiânia (GO), com $\mathrm{R} \$ 3,0$ bilhóes, que, apesar do volume de desembolsos menor, apresentou no período o financiamento de um conjunto maior de atividades - no entanto, se destacam a indústria de produtos alimentícios (com 50,0\% dos recursos), a produção de borracha e plástico $(8,6 \%)$ e a indústria de confecçôes, vestuário e acessórios $(5,2 \%)$.

No estado do Mato Grosso do Sul, sobressaem as aglomerações de Três Lagoas (MS), com cerca de R \$10,2 bilhóes, 70,7\% voltados para celulose papel e 19\%, para a indústria química (ligada à produção de fertilizantes nitrogenados e produtos agroquímicos, setores considerados prioritários para a região), ambos ligados à área de insumos 
básicos - AIB (Bacellar e Nali, 2014b); e Dourados (MS), com mais de R \$ 3,7 bilhóes, dois quais $72,8 \%$ foram para coque, petróleo e combustivel (vinculados à cadeia sucroenergética e de biocombustíveis) e 22,8\%, para produtos alimentícios.

Por fim, na mesma região, no estado do Mato Grosso, destaca-se a aglomeração de Alto Teles Pires (MT), com R \$2,3 bilhôes, 80,2\% para produtos alimentícios e 7,8\% para a atividade de coque, petróleo e combustivel, que, assim como nos casos anteriores, está associada à produção de combustíveis de fontes renováveis. E, seguida dela, a aglomeração industrial da capital, Cuiabá (MT), com aproximadamente $\mathrm{R}$ \$ 1,4 bilhão, 27,7\% desse montante destinado à produção de outros equipamentos de transporte; $27,6 \%$, ao processamento de minerais não metálicos, vinculados à nova unidade da Votorantim Cimentos; e 20,8\% orientados à indústria de alimentos e bebidas.

Posto isso, o que se observa ao se analisarem os desembolsos para as aglomeraçóes, em termos absolutos, é um padrão de atuação do banco orientada, principalmente, para as regióes industriais mais maduras e seu entorno; e, pontualmente, para outras localidades, como para o Norte, o Nordeste e o Centro-Oeste. No entanto, ao analisar a variação dos recursos entre os períodos nas AIRs, AIPs e microrregióes com menos de mil empregos industriais, especialmente em meio à ascensão dos desembolsos, fica explícito o esforço do BNDES para promover uma mudança estrutural no território, com o aumento da pujança dos investimentos, principalmente, nas microrregióes do Centro-Oeste, do Norte e do Nordeste (mapa 2).

O crescimento dos desembolsos entre 2000-2004 e 2005-2009 ocorreu, de modo mais predominante, no eixo do noroeste paulista, rumo ao triângulo mineiro e à região Centro-Oeste. As regióes Sudeste e Centro-Oeste destacam-se por reterem 35 das 64 microrregióes com ganhos acima de dez vezes da média nacional (gráfico 2). No período de crescimento subsequente, entre 2005-2009 e 2010-2014, os ganhos acima de dez vezes acima da média nacional estiveram concentrados, em grande medida, numa área que abrange o interior do Nordeste em direção ao Norte, englobando a regiâo do semiárido brasileiro9 e a região do Matopiba. ${ }^{10}$

9. Semiárido brasileiro é uma região caracterizada pelo clima seco, com poucas chuvas e elevada evapotranspiração, definida na Lei federal no 7.827, de 27 de setembro de 1989, e delimitada pelo Conselho Deliberativo (Condel) da Superintendência do Desenvolvimento do Nordeste (Sudene), por meio da Lei Complementar nํ 125, de 3 de janeiro de 2007. 10. A região do Matopiba abrange 337 municípios, abarcando todo o estado do Tocantins, mais o oeste baiano e o sul do Maranhão e do Piauí, em uma área de 73.173 .485 há, que cobre 51\% da área total dos quatro estados. Região caracterizada por um processo de expansão do agronegócio nas últimas décadas, em particular para a produção de commodities, tais como: algodão, cana-de-açúcar, milho e soja (Pereira, Porcionato e Castro, 2018). 
MAPA 2

Microrregiões do Brasil: crescimento dos desembolsos do BNDES para a indústria (extrativa e de transformação) em relação à dinâmica nacional, em períodos selecionados ${ }^{1,2,3}$

2A - Crescimento dos desembolsos entre os períodos 2000-2004 e 2005-2009

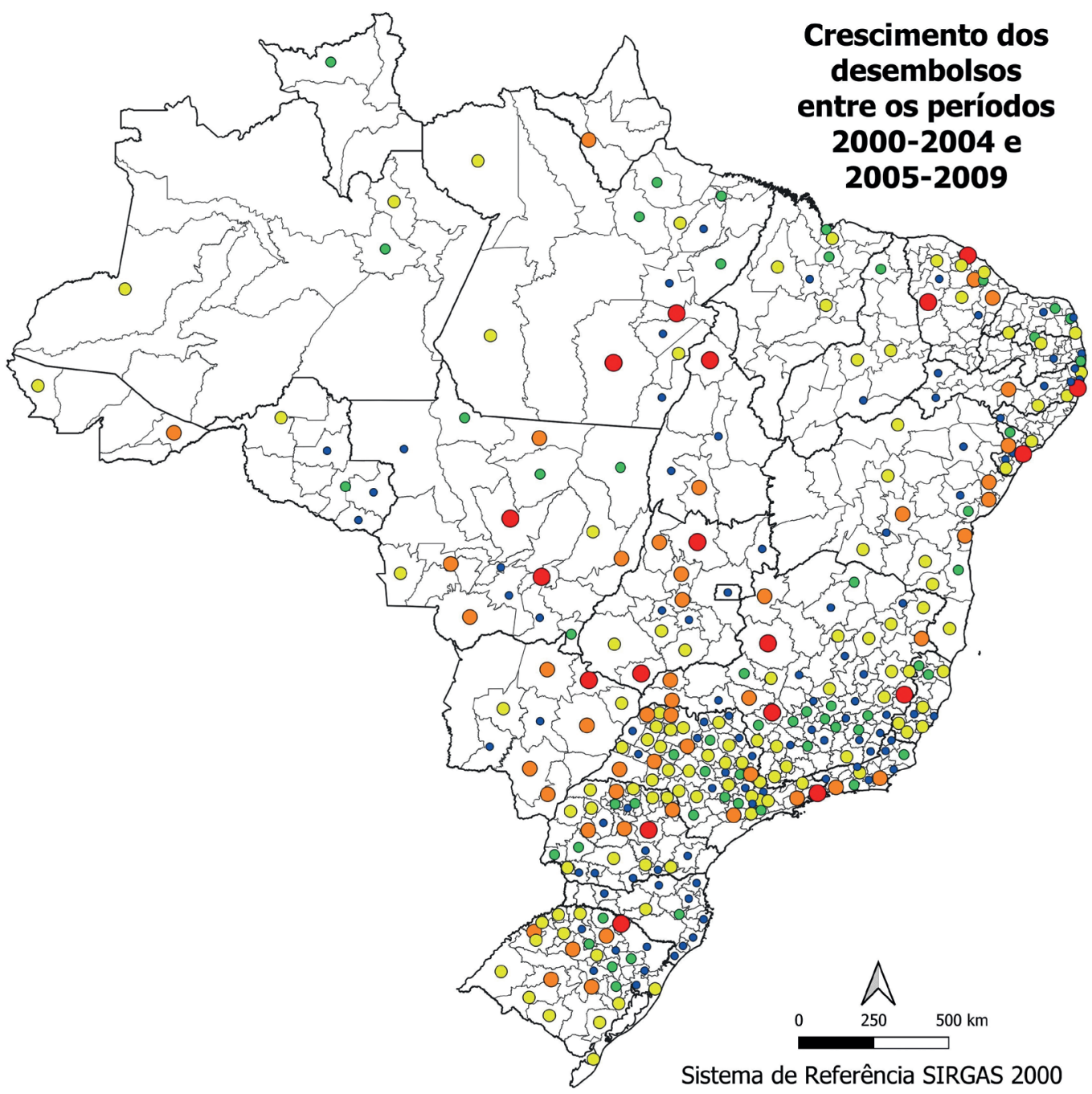

\section{Grupo de microrregiões segundo}

\section{o crescimento dos desembolsos}

- abaixo da média nacional [97]

- entre a média e até duas vezes a média nacional [55]

- acima de 2 vezes e até 10 vezes a média nacional [106]

- acima de 10 vezes e até 50 vezes a média nacional [46]

- acima de 50 vezes a média nacional [18] 
2B - Crescimento dos desembolsos entre os períodos 2005-2009 e 2010-2014

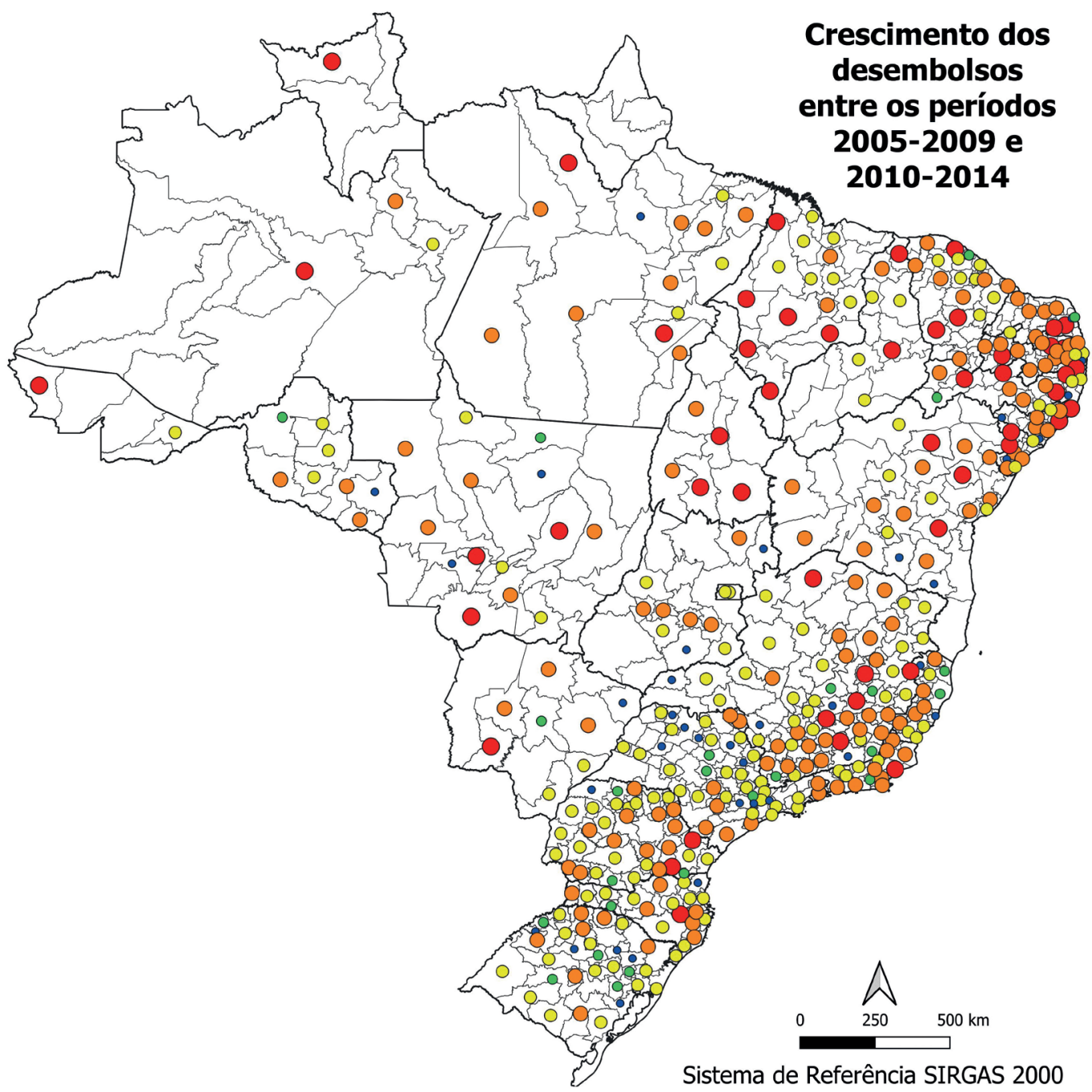

\section{Grupo de microrregiões segundo \\ o crescimento dos desembolsos}

- abaixo da média nacional [37]

- entre a média e até duas vezes a média nacional [25]

- acima de 2 vezes e até 10 vezes a média nacional [146]

- acima de 10 vezes e até 50 vezes a média nacional [143]

- acima de 50 vezes a média nacional [50]

Elaboração dos autores.

Notas: 'Valores monetários deflacionados pelo IGP-DI, da FGV, a preços de 2018.

${ }^{2}$ Dados de desembolsos apenas de municípios especificados.

${ }^{3}$ Crescimento dado por, em que $t$ é o período corrente e $t-1$, o período anterior. 
Como revela o gráfico 2, das 223 microrregiōes com ganhos acima de dez vezes da média nacional, 126 pertencem às regiôes Norte e Nordeste. Muito embora o montante de recursos destinados a cada uma dessas microrregióes seja irrisório quando comparado aos volumes destinados às regiốes preferenciais (área do polígono e sua expansão, bem como o litoral e as principais capitais e seu entorno), esse esforço denota relevância para a emersão de possíveis novos polos, capazes de alterar as estruturas produtivas locais (mapa 2).

\section{GRÁFICO 2}

Número de microrregiões com crescimento de desembolsos, segundo a região e a intensidade de crescimento, entre períodos selecionados

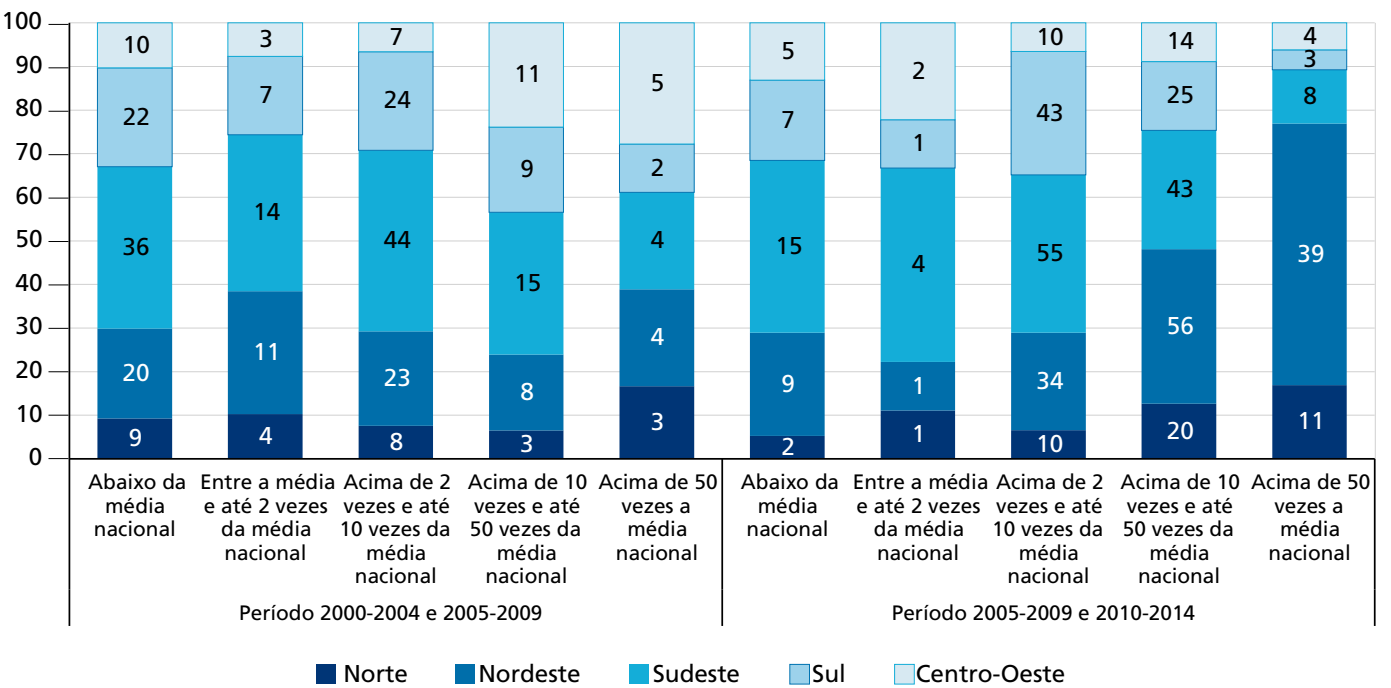

Elaboração dos autores com base nos resultados da pesquisa.

Em síntese, as aglomeraçóes do Sudeste-Sul preservam grande relevância, por concentrarem parcela significativa dos desembolsos, sobretudo em suas aglomeraçôes industriais acima de 10 mil empregados. A regiâo Sudeste, embora tenha a primazia nos desembolsos, vem perdendo paulatinamente sua participação em todos os tipos de aglomeraçôes. A região Sul, por seu turno, apresenta crescimento nos desembolsos, guiada por suas AIRs. Na regiáo Norte, apesar de as AIRs absorverem a maior parcela dos recursos, é em suas AIPs (tipo I e II) que o crescimento e a dinâmica dos desembolsos se revelam de modo mais intenso. No Nordeste os principais agrupamentos beneficiados foram aqueles abaixo de 10 mil empregos industriais. No Centro-Oeste foram mais favorecidas, ao longo do período de crescimento de desembolsos do BNDES (2000-2014), as AIRs e as AIPs do tipo I. Muito embora haja permanência do padrão geral de distribuição, é possível observar certo grau de desconcentração da atuação do BNDES no sentido das regiôes alvo da política regional. 


\section{EVOLUÇÃO E DISTRIBUIÇÃO DOS DESEMBOLSOS SOBRE A INFRAESTRUTURA}

Esta seção expóe a evolução e a distribuição dos desembolsos sobre a infraestrutura, a partir de uma perspectiva setorial e de múltiplas escalas regionais, entre 2000 e 2018. Tal como na segunda seção, foram utilizados os dados de desembolsos por municípios especificados e atividades industriais segundo a CNAE 2.0 provenientes do BNDES e o IGP/FGV para deflacionar a série de dados.

O padrão dos desembolsos sobre a infraestrutura seguiu uma trajetória similar ao da indústria (extrativa e de transformação) e do total dos desembolsos, vistos na primeira seção, com intenso crescimento, entre 2000 e 2010; manutenção em patamar elevado dos desembolsos, entre 2010 e 2014; e abrupta queda, entre 2015 e 2018 (gráfico 3).

GRÁFICO 3

Evolução dos desembolsos do BNDES para a infraestrutura, em termos reais (2000-2018) (Em R\$ milhões)

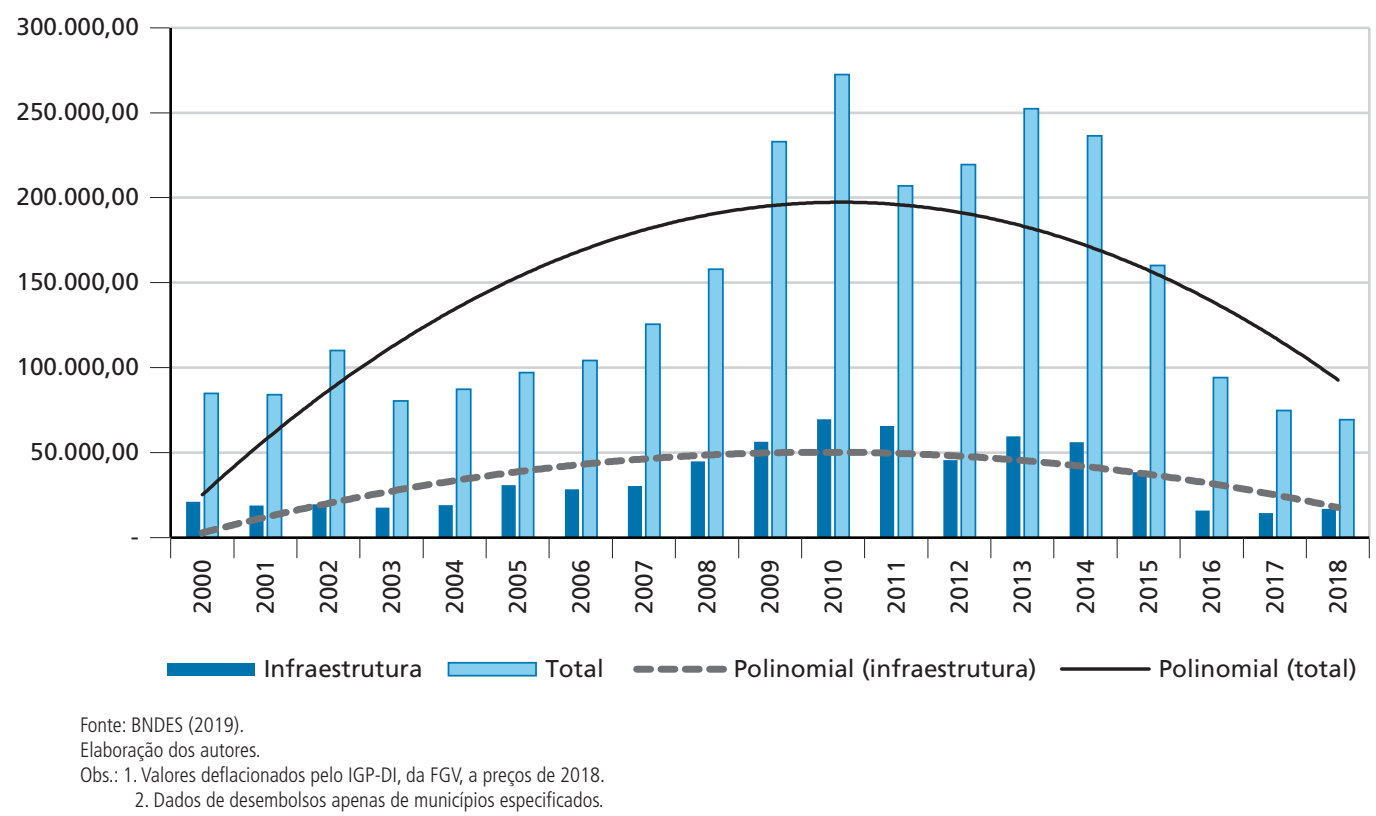

No que se refere ao padrão de distribuição dos desembolsos no território brasileiro, na tabela 5 e na tabela 6, é possível observar que, entre 2000 e 2018, o Sudeste, assim como na indústria, se destaca na absorção dos recursos, com cerca de R \$ 669,6 bilhóes, 
48,3\% do total de desembolsos para a infraestrutura. O financiamento da infraestrutura na região, no período, foi direcionado principalmente para transporte rodoviário (21,0\%); outros transportes ${ }^{11}$ (7,3\%); e energia elétrica (6,6\%), que juntos totalizam mais de $72,1 \%$ dos desembolsos do BNDES para a infraestrutura no Sudeste. Nessa regiáo e no Brasil, São Paulo e Rio de Janeiro foram os estados que receberam o maior volume de financiamento de projetos, absorvendo, respectivamente, $23,5 \%$ e $15,1 \%$ do montante nacional destinado à infraestrutura.

TABELA 5

Participação nos desembolsos do BNDES' , do acumulado entre 2000 e 2018, segundo as regiões e os setores da infraestrutra

(Em \%)

\begin{tabular}{lcccccc}
\hline \multicolumn{1}{c}{ Setor } & Norte & Nordeste & Sudeste & Sul & Centro-Oeste & Brasil \\
\hline Atividades auxiliares de transporte & 0,1 & 0,6 & 4,7 & 1,6 & 0,5 & 7,5 \\
Construção & 0,2 & 0,1 & 1,9 & 0,3 & 0,0 & 2,6 \\
Energia elétrica & 6,1 & 5,9 & 6,6 & 3,8 & 1,6 & 24,0 \\
Serviços de utilidade pública & 0,1 & 0,2 & 1,8 & 0,2 & 0,1 & 2,6 \\
Telecomunicações & 0,1 & 1,0 & 3,5 & 0,5 & 1,5 & 6,5 \\
Transporte ferroviário & 0,2 & 0,0 & 1,6 & 0,4 & 0,5 & 2,7 \\
Transporte rodoviário & 1,6 & 4,9 & 21,0 & 12,5 & 3,9 & 43,9 \\
Outros transportes & $\mathbf{0 , 9}$ & $\mathbf{1 , 2}$ & $\mathbf{7 , 3}$ & $\mathbf{0 , 8}$ & $\mathbf{0 , 1}$ & 10,3 \\
Total & $\mathbf{9 , 2}$ & $\mathbf{1 3 , 9}$ & $\mathbf{4 8 , 3}$ & $\mathbf{2 0 , 2}$ & $\mathbf{8 , 3}$ & $\mathbf{1 0 0}$ \\
\hline
\end{tabular}

Fonte: BNDES (2020).

Elaboração dos autores.

Nota: 1 Dados de desembolsos apenas de municípios especificados.

A região Sul do país se apresenta como o segundo principal destino dos desembolsos, com 20,2\% do total designado à infraestrutura no Brasil. Os principais projetos financiados na região estiveram ligados a transporte rodoviário $(12,5 \%)$ e energia elétrica $(3,8 \%)$, que representavam $16,3 \%$ do total para a infraestrutura brasileira e $80,8 \%$ do montante destinado à região (tabela 5 e tabela 6 ).

Em contrapartida, as regióes alvo da política regional (Norte, Nordeste e Centro-Oeste) juntas somaram cerca de 31,4\% do total dos desembolsos entre 2000 e 2018. Muito embora concentrem ainda parcela inferior a um terço do total dos

11. 0 grupo de outros transportes inclui uma série de projetos, tais como gasodutos e minerodutos. 
desembolsos, a parcela absorvida pelas regióes na infraestrutura é superior àquela capturada pela atividade industrial no mesmo período (19,3\%), o que sinaliza que a atuação do BNDES na infraestrutura foi mais equânime entre as regióes do que na indústria.

Entre essas regióes, a região Nordeste foi a que mais absorveu recursos (13,9\%), cerca de R\$92,8 bilhóes. O financiamento, entre 2000 e 2018, esteve canalizado, principalmente, para os ramos de energia elétrica $(5,9 \%)$ e transporte rodoviário $(4,9 \%)$, que somados representam $10,8 \%$ do total nacional e $77,6 \%$ do montante designado à infraestrutura da região. Os desembolsos mais representativos foram direcionados aos estados da Bahia (5,2\%), do Ceará (2,4\%), de Pernambuco (2,0\%) e do Rio Grande do Norte $(1,5 \%)$, que juntos detinham $80,1 \%$ dos recursos destinados à infraestrutura do nordeste.

TABELA 6

Total dos desembolsos para infraestrutura e participação relativa em períodos selecionados ${ }^{1,2}$ - Brasil, regiões e UFs

\begin{tabular}{|c|c|c|c|c|c|c|c|c|}
\hline \multirow{2}{*}{ Regiões/UFs } & \multicolumn{4}{|c|}{$\begin{array}{l}\text { Desembolsos em termos absolutos } \\
\text { (R\$ milhões) }\end{array}$} & \multicolumn{4}{|c|}{$\begin{array}{c}\text { Desembolsos em termos relativos } \\
(\%)\end{array}$} \\
\hline & $\begin{array}{l}\text { De } 2000 \text { a } \\
2004\end{array}$ & $\begin{array}{l}\text { De } 2005 \text { a } \\
2009\end{array}$ & $\begin{array}{l}\text { De } 2010 \text { a } \\
2014\end{array}$ & $\begin{array}{l}\text { De } 2015 \text { a } \\
2018\end{array}$ & $\begin{array}{l}\text { De } 2000 \text { a } \\
2004\end{array}$ & $\begin{array}{l}\text { De } 2005 \text { a } \\
2009\end{array}$ & $\begin{array}{l}\text { De } 2010 \text { a } \\
2014\end{array}$ & $\begin{array}{l}\text { De } 2015 \text { a } \\
2018\end{array}$ \\
\hline Norte & $6.824,36$ & $21.754,27$ & $28.877,22$ & $4.384,42$ & 7,08 & 11,39 & 9,74 & 5,12 \\
\hline Rondônia & 115,35 & $8.719,19$ & $19.176,51$ & $1.767,15$ & 0,12 & 4,56 & 6,47 & 2,07 \\
\hline Acre & 3,84 & 158,91 & 122,53 & 45,20 & 0,00 & 0,08 & 0,04 & 0,05 \\
\hline Amazonas & $1.188,70$ & $5.476,61$ & $2.154,23$ & 641,32 & 1,23 & 2,87 & 0,73 & 0,75 \\
\hline Roraima & - & 27,81 & 82,13 & 21,72 & - & 0,01 & 0,03 & 0,03 \\
\hline Pará & $4.426,02$ & $2.231,05$ & $2.580,35$ & 601,98 & 4,59 & 1,17 & 0,87 & 0,70 \\
\hline Amapá & 61,02 & 116,51 & $1.174,97$ & 499,12 & 0,06 & 0,06 & 0,40 & 0,58 \\
\hline Tocantins & $1.029,42$ & $5.024,19$ & $3.586,50$ & 807,93 & 1,07 & 2,63 & 1,21 & 0,94 \\
\hline Nordeste & $13.379,70$ & $23.371,53$ & $37.372,97$ & $18.644,24$ & 13,88 & 12,24 & 12,60 & 21,79 \\
\hline Maranhão & $1.271,14$ & $1.626,54$ & $4.203,61$ & 603,36 & 1,32 & 0,85 & 1,42 & 0,71 \\
\hline Piauí & 259,29 & 302,53 & $1.473,03$ & $2.262,68$ & 0,27 & 0,16 & 0,50 & 2,64 \\
\hline Ceará & $1.572,81$ & $3.228,40$ & $7.993,16$ & $2.978,06$ & 1,63 & 1,69 & 2,70 & 3,48 \\
\hline Rio Grande do Norte & 413,21 & 922,55 & $5.898,90$ & $2.835,31$ & 0,43 & 0,48 & 1,99 & 3,31 \\
\hline Paraíba & $1.327,04$ & 783,06 & $1.150,21$ & 75,49 & 1,38 & 0,41 & 0,39 & 0,09 \\
\hline Pernambuco & $1.550,25$ & $4.592,81$ & $4.802,83$ & $2.247,82$ & 1,61 & 2,40 & 1,62 & 2,63 \\
\hline Alagoas & $1.314,30$ & 460,97 & 705,00 & 57,42 & 1,36 & 0,24 & 0,24 & 0,07 \\
\hline Sergipe & 146,20 & 225,43 & 859,90 & 116,35 & 0,15 & 0,12 & 0,29 & $\begin{array}{l}0,14 \\
\text { (Continua) }\end{array}$ \\
\hline
\end{tabular}


(Continuação)

\begin{tabular}{|c|c|c|c|c|c|c|c|c|}
\hline \multirow{2}{*}{ Regiões/UFs } & \multicolumn{4}{|c|}{$\begin{array}{l}\text { Desembolsos em termos absolutos } \\
\text { ( } R \$ \text { milhões) }\end{array}$} & \multicolumn{4}{|c|}{$\begin{array}{l}\text { Desembolsos em termos relativos } \\
\qquad(\%)\end{array}$} \\
\hline & $\begin{array}{l}\text { De } 2000 \text { a } \\
2004\end{array}$ & $\begin{array}{l}\text { De } 2005 \text { a } \\
2009\end{array}$ & $\begin{array}{l}\text { De } 2010 \text { a } \\
2014\end{array}$ & $\begin{array}{l}\text { De } 2015 \text { a } \\
2018\end{array}$ & $\begin{array}{l}\text { De } 2000 \text { a } \\
2004\end{array}$ & $\begin{array}{l}\text { De } 2005 \text { a } \\
2009\end{array}$ & $\begin{array}{l}\text { De } 2010 \text { a } \\
2014\end{array}$ & $\begin{array}{l}\text { De } 2015 \text { a } \\
\quad 2018\end{array}$ \\
\hline Bahia & $5.525,45$ & $11.229,23$ & $10.286,32$ & $7.467,76$ & 5,73 & 5,88 & 3,47 & 8,73 \\
\hline Sudeste & $45.824,46$ & $91.876,32$ & $146.469,02$ & $39.659,34$ & 47,52 & 48,10 & 49,39 & 46,35 \\
\hline Minas Gerais & $5.534,94$ & $14.686,19$ & $23.851,86$ & $5.240,78$ & 5,74 & 7,69 & 8,04 & 6,13 \\
\hline Espírito Santo & $2.023,28$ & $6.899,91$ & $6.183,74$ & 739,85 & 2,10 & 3,61 & 2,09 & 0,86 \\
\hline Rio de Janeiro & $14.932,43$ & $23.217,13$ & $47.547,41$ & $15.202,52$ & 15,49 & 12,15 & 16,03 & 17,77 \\
\hline São Paulo & $23.333,80$ & $47.073,09$ & $68.886,01$ & $18.476,20$ & 24,20 & 24,64 & 23,23 & 21,60 \\
\hline Sul & $18.050,87$ & $36.397,07$ & $63.313,06$ & $17.721,22$ & 18,72 & 19,05 & 21,35 & 20,71 \\
\hline Paraná & $5.868,09$ & $14.061,57$ & $23.348,01$ & $6.871,31$ & 6,09 & 7,36 & 7,87 & 8,03 \\
\hline Santa Catarina & $6.185,91$ & $10.192,16$ & $20.849,98$ & $4.904,76$ & 6,42 & 5,34 & 7,03 & 5,73 \\
\hline Rio Grande do Sul & $5.996,88$ & $12.143,34$ & $19.115,07$ & $5.945,15$ & 6,22 & 6,36 & 6,45 & 6,95 \\
\hline Centro-Oeste & $12.348,86$ & $17.620,76$ & $20.537,62$ & $5.147,63$ & 12,81 & 9,22 & 6,93 & 6,02 \\
\hline Mato Grosso do Sul & 736,88 & $1.636,92$ & $3.022,30$ & 931,71 & 0,76 & 0,86 & 1,02 & 1,09 \\
\hline Mato Grosso & $1.170,12$ & $6.412,40$ & $7.430,35$ & $2.286,14$ & 1,21 & 3,36 & 2,51 & 2,67 \\
\hline Goiás & $1.749,00$ & $5.661,22$ & $6.513,76$ & $1.264,34$ & 1,81 & 2,96 & 2,20 & 1,48 \\
\hline Distrito Federal & $8.692,86$ & $3.910,23$ & $3.571,22$ & 665,43 & 9,01 & 2,05 & 1,20 & 0,78 \\
\hline Brasil & $96.428,25$ & $191.019,96$ & $296.569,88$ & $85.556,86$ & 100 & 100 & 100 & 100 \\
\hline
\end{tabular}

$\mathrm{Na}$ sequência da região Nordeste, está o Norte, com 9,2\% dos desembolsos nacionais entre 2000 e 2018. O volume mais representativo dos recursos foi destinado a energia elétrica $(6,1 \%)$ e transporte rodoviário $(1,6 \%)$, correspondendo a $87,7 \%$ do montante destinado à região. Os principais estados na absorção dos recursos foram Rondônia (4,4\%), Tocantins (1,6\%), Pará (1,5\%) e Amazonas (1,4\%), que juntos somam mais de $96,3 \%$ do total dos desembolsos da região Norte.

Por fim, o Centro-Oeste do país, com $8,3 \%$ do total dos desembolsos para a infraestrutura, destinados, em grande medida, ao transporte rodoviário (3,9\%) e aos empreendimentos de energia elétrica $(1,6 \%)$, consolidando $66,3 \%$ do montante designado à regiáo. Do total empreendido na regiáo, Mato Grosso (2,6\%), Distrito Federal (2,5\%) e Goiás $(2,3 \%)$ concentram a maior parcela, retendo $88,6 \%$ do total destinado ao Centro-Oeste.

Posto isso, os resultados citados indicam que, diferentemente do que ocorreu com a indústria no período de ascensão dos desembolsos (2000-2004; 2005-2009; e 
2010-2014), as regióes mais desenvolvidas (Sudeste e Sul) apresentam certa ampliação na absorção dos recursos. Tal protagonismo pode ser explicado pela intensa atividade econômica e social das regiôes, que tende a pressionar a infraestrutura logística de diversas formas, seja pelas cadeias de suprimento de diversos produtos industriais e agrícolas, seja pelo crescimento urbano.

As regióes citadas apresentam infraestrutura logística e de energia elétrica, tanto de geração quanto de distribuição e transmissão, bastante diversificada. No entanto, seus gargalos, sobretudo na regiáo Sudeste, antigos e conhecidos, tendem a pressionar a necessidade de recursos para superar seus constrangimentos. Sáo exemplares desses entraves: i) congestionamentos rodoviários nas regióes metropolitanas e nas proximidades dos portos urbanos; ii) utilização de frota envelhecida nas regiōes portuárias; iii) existência de grande quantidade de passagens em nível nas ferrovias; iv) expansão urbana pouco controlada; v) necessidade de infraestrutura rodoferroviária de contorno dos grandes centros urbanos para o aumento da eficiência geral da logística; vi) baixa eficiência da distribuição urbana; e vii) capacidade insuficiente de portos estratégicos para atender à produção industrial (Siffert Filho et al., 2014b; 2014c).

Por um lado, nas regiôes Norte, Nordeste e Centro-Oeste, a baixa extensão, densidade e qualidade na oferta dos serviços públicos, bem como a carente articulação das redes de integração intrarregional, nacional e, mesmo, continental, são grandes desafios que se impóem para a melhora da qualidade de vida para a populaçáo local e para o incremento da competitividade econômica as regióes. Muito embora a participação no total nacional das regiôes alvo da política regional não tenha sido ampliada de modo expressivo (exceto a região Norte), os recursos, nos períodos 2000-2004 e 2010-2014, mais que quadruplicaram no Norte, mais que dobraram no Nordeste e aumentaram mais de 50\% no Centro-Oeste.

Esse crescimento verificado é derivado, principalmente, dos planos estaduais de desenvolvimento, com investimentos em infraestrutura portuária, rodoviária e de saneamento, além de financiamento à construçáo de hospitais, escolas e outros equipamentos públicos (Ramos e Cotovio, 2014; Campos, Leal e Ramos, 2014; Braga e Ramos, 2014). A Área de Infraestrutura Social do BNDES possui grande relevo nesse processo, financiando projetos específicos de saneamento, mobilidade urbana, saúde e educação. São destaques, nos períodos 2005-2009 e 2010-2014, o Programa Emergencial de Financiamento aos Estados e Distrito Federal (PEF), criado em 2009, e o Programa de Apoio ao Investimento dos Estados e Distrito Federal (Proinveste), criado em 2012, que objetivavam declaradamente sustentar a capacidade de investimento dos entes federativos num período de retração econômica, com intuito de evitar a retraçáo nos investimentos 
sociais (Ramos e Cotovio, 2014; Campos, Leal e Ramos, 2014; Braga e Ramos, 2014).

Em face do exposto, os resultados reforçam as evidências de que o BNDES tem mantido o padrão de centralidade dos desembolsos para a infraestrutura nas regióes Sul e Sudeste do Brasil, sobretudo para o setor de transporte rodoviário, que juntos somaram 33,5\% dos desembolsos no período 2000-2018 nessas macrorregióes. Ademais, é preciso ressaltar que, diferentemente do que ocorreu na indústria, houve ampliação na absorçáa dos recursos nas regióes do Sul e Sudeste no período de ascensáo dos desembolsos. No entanto, as aglomeraçóes com mais de 10 mil empregados perdem participação na absorção dos recursos, o que sinaliza que a ampliação é mais acelerada nos aglomerados menos robustos. Por seu turno, as regióes alvo da política regional apresentam um acréscimo dos desembolsos, conduzido pela Área de Infraestrutura Social do BNDES, sobretudo a partir de 2009. Nas regióes Nordeste e Norte, os principais projetos estiveram relacionados à energia elétrica. No Centro-Oeste, também alvo da política regional, o banco direcionou o financiamento dos projetos para o setor de transporte rodoviário no período em análise.

\section{TRAJETÓRIA DOS DESEMBOLSOS SOBRE A INFRAESTRUTURA NAS AIRs E AIPs}

Nesta seção são expostos os resultados relacionados à evolução dos desembolsos do BNDES e sua distribuição na infraestrutura das AIRs e AIPs no período 2000-2018. O objetivo é analisar se as trajetórias regionais de atuação do BNDES ocorreram no sentido de uma mudança estrutural em direção às regiôes alvo da política regional ou como reforço da trajetória nas regióes industriais mais maduras. A ênfase, assim como na terceira seção, é dada ao volume de recursos aplicados, ao crescimento dos desembolsos e ao tamanho do emprego industrial das microrregióes a que se destinam os recursos.

No que concerne à relação entre o tamanho do emprego industrial e o valor dos desembolsos para a infraestrutura, a tabela 7 elucida que, no período analisado, as aglomerações com mais de 10 mil empregos industriais foram responsáveis por mais de 70\% dos desembolsos para a infraestrutura. Entre 2000 e 2004, responderam por $74,1 \%$ do total dos recursos; entre 2005 e 2009, por 66,2\%; em 2010-2014, por 62,5\%; e entre 2015 e 2018, por 59,1\%. O montante dos desembolsos dessas AIRs passou de R \$ 71,4 bilhóes, com média de R \$ 721,29 milhóes, no período 2000-2004, para um total de $\mathrm{R} \$ 185,4$ bilhóes, com média de $\mathrm{R} \$ 1,2$ bilhão por AIR, no período 
de ápice dos desembolsos, entre 2010 e 2014. Ao longo de todo o período analisado, foi destinado à tais aglomeraçóes um valor expressivo, mais de $\mathrm{R} \$ 433,9$ bilhóes.

No aspecto macrorregional, os resultados dos desembolsos indicam a centralidade das aglomeraçóes industriais com mais de 10 mil empregos industriais do eixo Sul-Sudeste na absorção dos recursos. As AIRs do Sudeste concentraram, ao longo do período, mais de $40 \%$ do total. Ao passo que as do Sul passaram a reter parcelas cada vez maiores do montante nacional, em meio ao período de ascensão dos desembolsos. Entre 2000 e 2004, elas representavam 9,9\% do total; entre 2005 e 2009, 12,8\%; e em 2010-2014, 13,7\%.

Por seu turno, as AIRs do Norte, Nordeste e Centro-Oeste juntas apresentaram paulatinamente queda em suas participaçóes. Entre 2000 e 2004, juntas elas detinham 22,1\% do total; entre 2005 e 2009, 12,9\%; em 2010-2014, 8,3\%; e entre 2015 e 2018, chegaram a 6,6\% do total dos recursos para a infraestrutura. Nota-se neste aspecto certa concentração regional, com o eixo Sul-Sudeste ampliando sua participação na captura dos recursos, o que tende a reforçar as trajetórias do ordenamento territorial em favor das áreas consolidadas.

Muito embora as AIRs das regiōes alvo da política regional percam participação nos desembolsos, emerge uma novidade em termos regionais. As aglomeraçóes abaixo de 10 mil empregos industriais nessas regióes obtiveram acréscimos em sua participação no valor dos desembolsos. Entre 2000 e 2004, juntas detinham 11,6\% do total; entre 2005 e 2009, 19,9\%; entre 2010 e 2014, 20,9\%; e entre 2015 e 2018, atingiram $26,4 \%$.

Na região Norte, no período de crescimento da atuação do BNDES, os principais agrupamentos beneficiados foram as AIPs do tipo II, cujos desembolsos saltaram de R\$ 5,5 bilhóes, entre 2000-2004, para aproximadamente R \$ 10,8 bilhões, entre 2005 e 2010, chegando a cerca de R \$22,9 bilhóes entre 2010-2014. Entre 2015-2018, em meio a queda generalizada dos desembolsos, as AIPs do tipo II preservaram a maior parcela na região, $\mathrm{R} \$ 3,1$ bilhóes. 


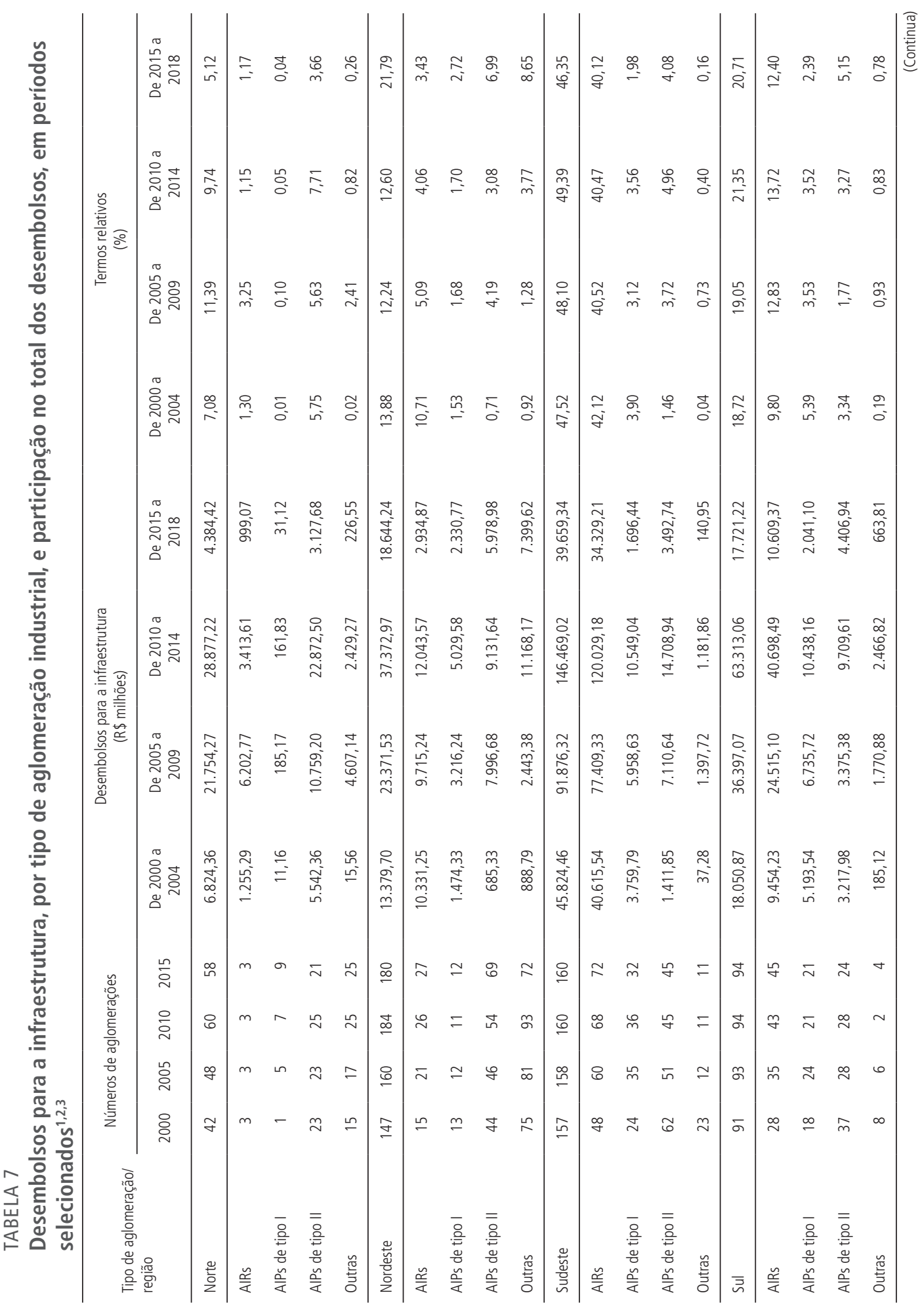




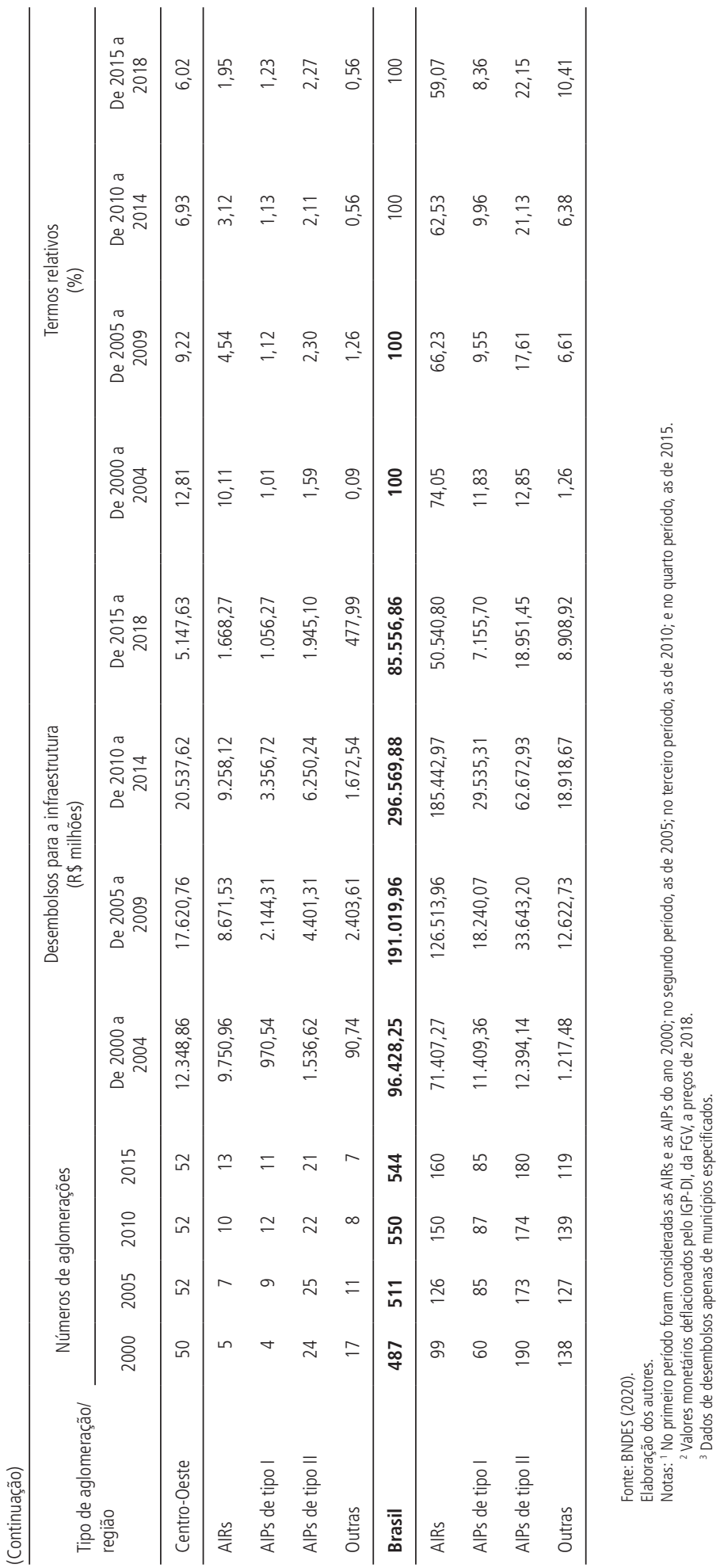

46 
Na regiāo Nordeste, ao longo do período 2000-2018, as AIRs foram predominantes na absorção dos recursos. Contudo, apresenta queda na participação dos recursos destinados à regiấo, ao passo que as aglomeraçóes com menos de 10 mil empregos revelam notória evoluçáo na captação dos desembolsos. Nos períodos 2000-2004 e 2005-2009, as AIPs do tipo II detiveram o maior desempenho, com os recursos destinados ao grupo saindo de $\mathrm{R}$ \$ 685,33 milhóes, entre 2000-2004, para mais de $\mathrm{R} \$ 3,2$ bilhôes, um valor onze vezes superior ao período inicial. Seguida deste grupo estáo as AIPs do tipo I e as aglomeraçóes com menos de mil empregos industriais, onde os desembolsos mais que dobraram. Por seu turno, nos períodos 2005-2009 e 2010-2014, ganham maior destaque na regiấo as aglomeraçóes com menos de mil empregos industriais, cujos recursos passaram de $\mathrm{R}$ 2,4 bilhôes para cerca de $\mathrm{R} \$ 11$,2 bilhôes.

Entre 2015-2018, no período de reduçáo generalizada de queda dos desembolsos, foram as aglomerações menos consolidadas que apresentaram reduções menos abruptas dos desembolsos. Enquanto as AIRs da região tiveram redução de mais de 70\%, as AIPs do tipo I tiveram perda de $54 \%$ e tanto as AIPs do tipo II quanto as aglomeraçóes com menos de mil empregos industriais, redução próxima de $35 \%$.

Por fim, as AIRs do Centro-Oeste preservaram a maior participação nos desembolsos na região, pelo menos até o período 2010-2014. Entretanto, a evolução dos recursos nas aglomeraçóes com menos de 10 mil ocupaçôes sobressai. No primeiro período, o montante designado às microrregiốes com menos de mil empregos passou de $R$ \$ 90,74 milhóes, entre 2000-2004, para $R$ \$ 2,4 bilhóes, entre 2005-2009, valor este 26 vezes superior ao do período inicial. Na mesma época, os recursos destinados às AIPs (tipo I e II) mais que dobraram.

Por seu turno, nos períodos 2005-2009 e 2010-2014, as AIPs (tipo I e tipo II) assumem posicionamento de destaque no crescimento, ao passo que as aglomeraçóes com menos de mil ocupaçóes perdem recursos. O movimento pode ser resultado da redução do número de microrregiôes com menos de mil empregos industriais, resultado da expansão do número de emprego, fazendo estas subirem de nível em termos de aglomeraçôes industriais. Esse comportamento explica também a ampliação dos desembolsos para regióes com camadas de empregos superiores. Nesses termos, o processo não deve ser visto como nocivo, mas benéfico, pois pode indicar que a atuação do banco no período anterior tenha favorecido o fortalecimento das aglomeraçóes industriais. 
No que toca à localização dessas aglomerações industriais, muito embora o BNDES tenha ampliado sua atuação no território, os grandes volumes de desembolsos possuem um padrão semelhante ao dos resultados apresentados para a indústria, caracterizado por grandes investimentos no eixo Sul-Sudeste da área do "polígono" e seu transbordo; nas principais capitais e territórios em seu entorno; e na faixa litorânea do Nordeste (mapa 3).

No eixo Sul-Sudeste, sobressaem nos grupos de ganhos médios a muito altos, nos diferentes períodos analisados, as aglomeraçóes já conhecidas, como: i) da RM de São Paulo e seu entono, marcadas pelas AIRs de São Paulo (SP), Campinas (SP), Guarulhos (SP), Osasco (SP) e Santos (SP); ii) a microrregião de Belo Horizonte (MG); iii) no Sul, onde se destacam as aglomerações de Curitiba (PR), Palmas (PR), Maringá (PR), Itajaí (SC), Curitibanos (SC), Porto Alegre (RS), Litoral Lagunar (RS), Caxias do Sul (RS) e Vacaria (RS); iv) a expansão do "polígono", no vetor Rio-Vitória, onde se destacam as AIRs do Rio de Janeiro (RJ), da Baía da Ilha Grande (RJ), de Macaé (RJ), de Campos dos Goytacazes (RJ), de Vitória (ES) e de Linhares (ES).

Para além da área Sul-Sudeste e seu transbordo, algumas aglomeraçóes no Nordeste, Norte e Centro-Oeste se destacam, ainda que ocupem grupos de ganhos baixos ou moderados. Na região Norte, entre 2000 e 2018, sobressaem as aglomerações das capitais de Rondônia, do Amazonas, do Pará e do Amapá. 
MAPA 3

Aglomerações industriais do Brasil: desembolsos do BNDES para a infraestrutura, em períodos selecionado ${ }^{1,2}$

3A - Período 2000-2004

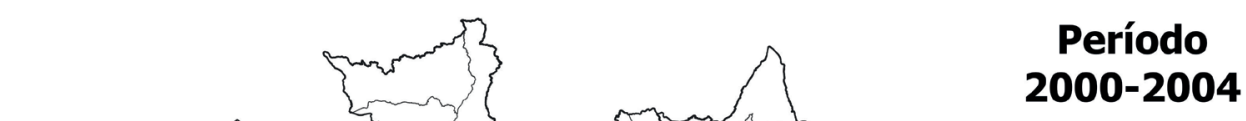

Desembolsos (em R\$)

- 112.056 - 311.281 .320 [285]

- $311.281 .320-1.117 .067 .716[26]$

- $1.117 .067 .716-2.554 .701 .406$ [10]

- $2.554 .701 .406-8.692 .855 .042$ [5]

- 8.692.855.042 - 12.010.433.754 [2]

\section{Período}

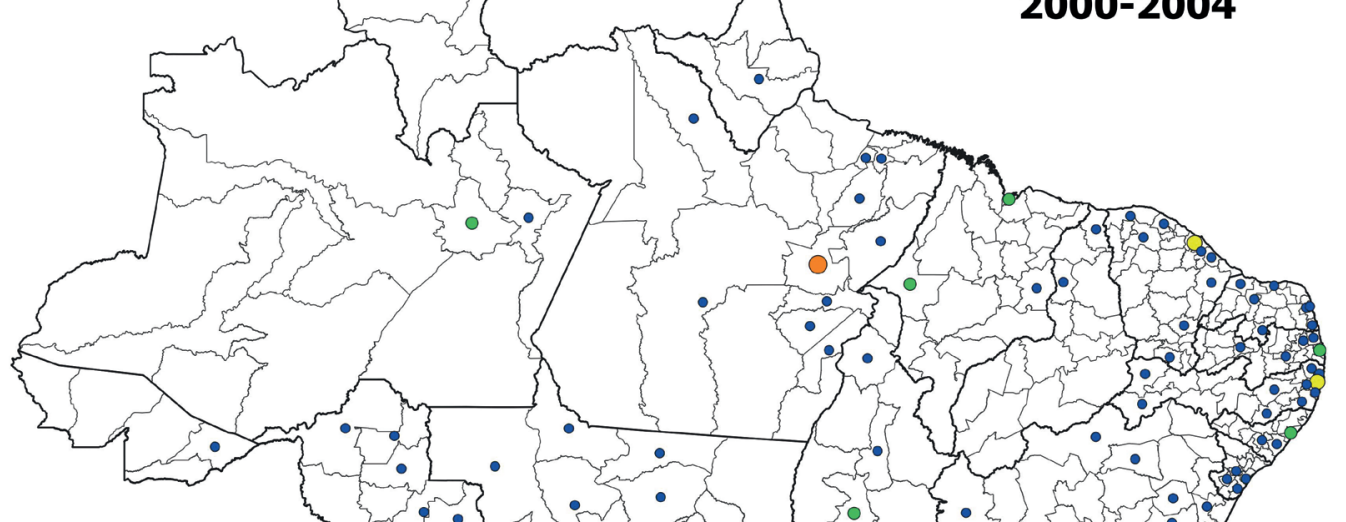


3B - Período 2005-2009

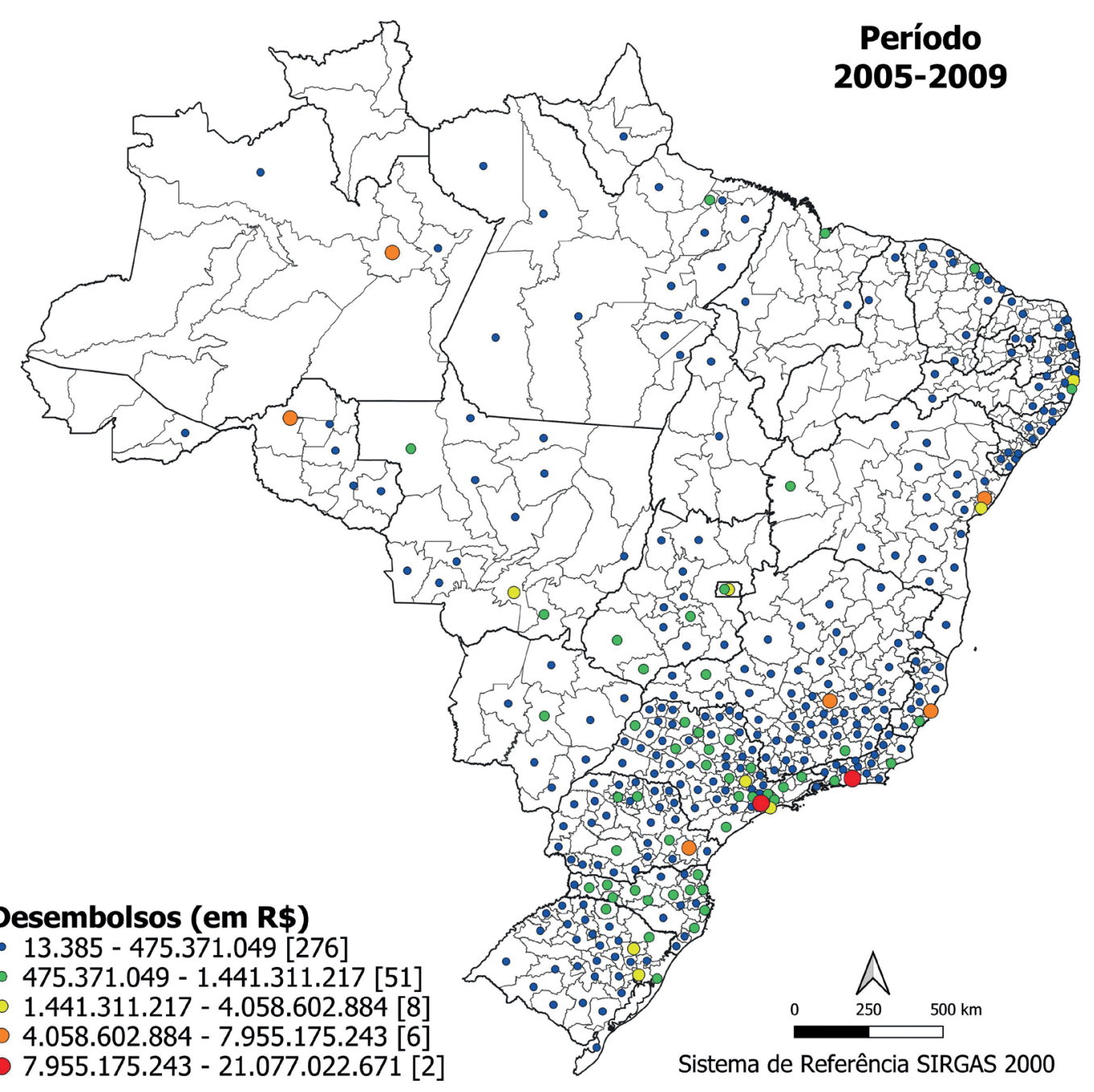




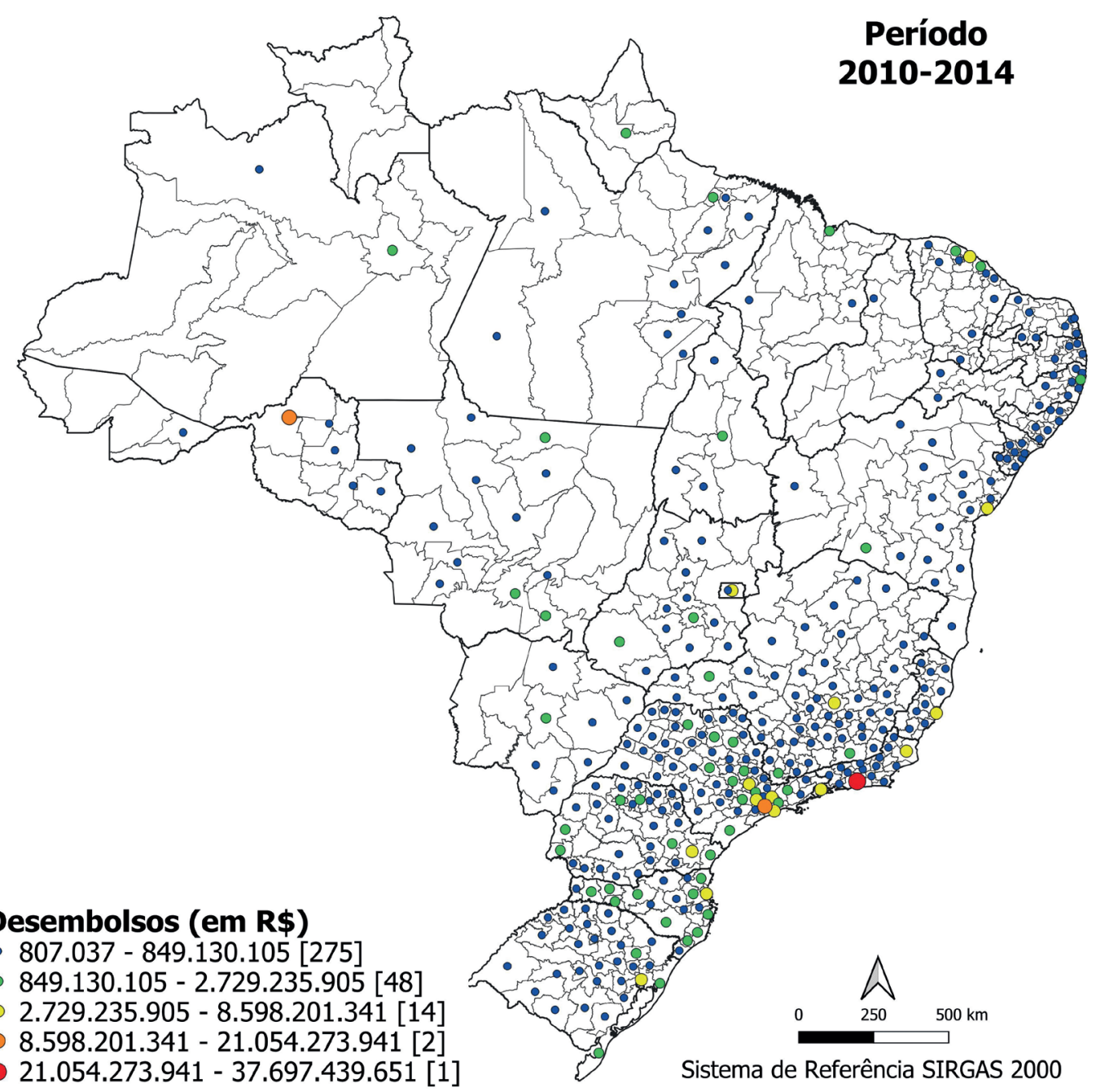




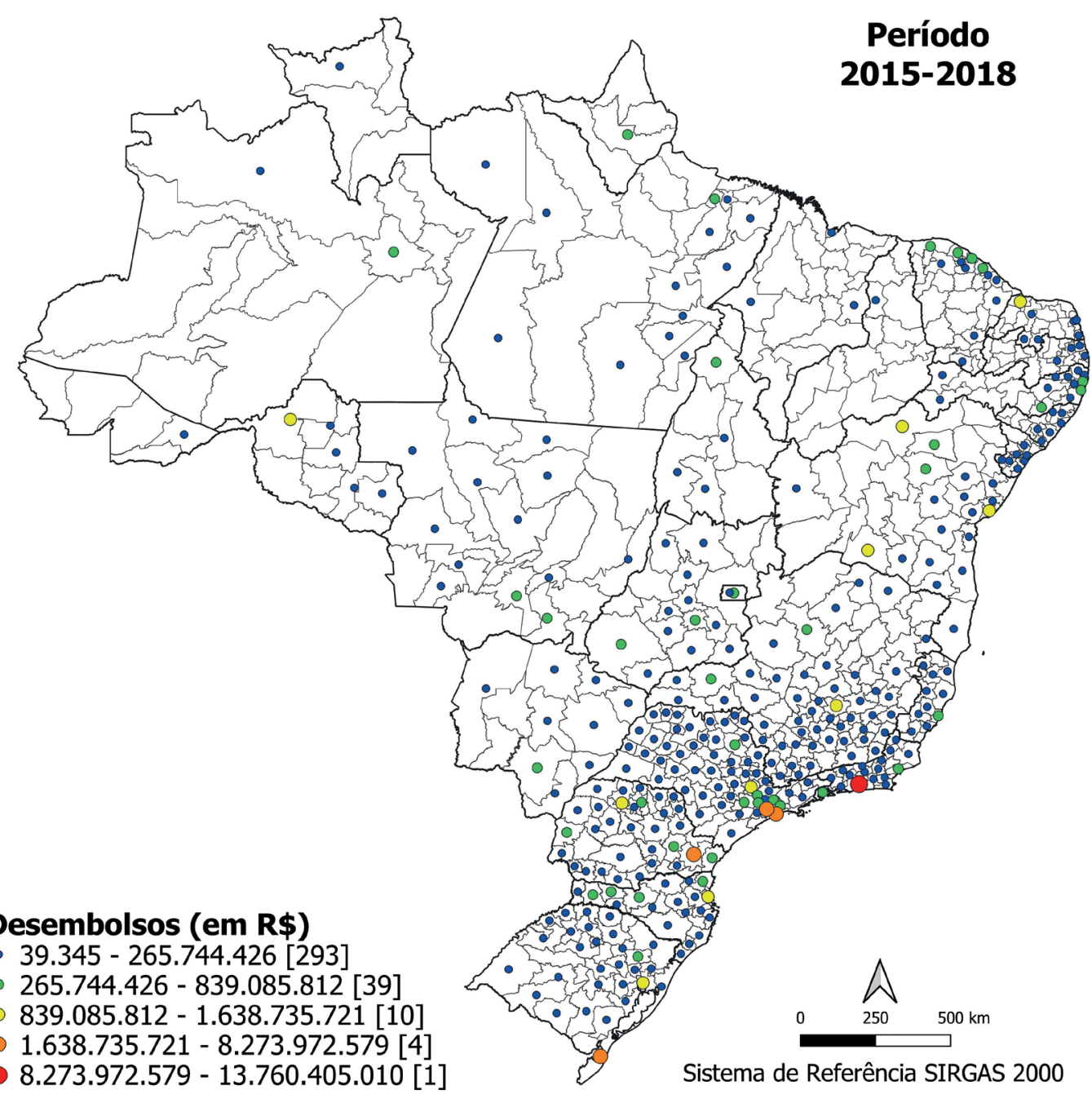

Elaboração dos autores.
Notas: ${ }^{~}$ Valores monetários deflacionados pelo IGP-DI, da FGV, a preços de 2018.
${ }^{2}$ Dados de desembolsos apenas de municípios especificados.

Em Roraima, a AIP de Porto Velho (RO) absorveu cerca de R\$ 27,9 bilhóes, destinados, sobretudo, ao setor de energia elétrica (97,0\%), vinculados aos projetos das hidrelétricas de Santo Antônio e de Jirau, no rio Madeira (Siffert Filho et al., 2014a). No Amazonas, a AIR de Manaus (AM) deteve R \$ 9,2 bilhóes, designados principalmente para a infraestrutura em transporte terrestre (71\%) e transporte aquaviário (10,3\%). No Pará, a AIR de Belém concentrou R \$ 2,4 bilhōes, associados, sobretudo, aos investimentos em transporte rodoviário $(65,5 \%)$ e outros sistemas de transporte $(21,6 \%)$. 
Também se destacam as AIPs de Macapá (AP) e Tucuruí (PA), com desembolsos de, respectivamente, $\mathrm{R}$ \$ 4,4 bilhôes e $\mathrm{R} \$ 1,8$ bilhão, vinculados principalmente ao projeto de ampliação da Usina de Tucuruí (BNDES, 2004) e dos trechos de interligação do sistema Tucuruí-Macapá-Manaus (Siffert Filho et al., 2014a).

Para além das capitais, cabe salientar a AIP do tipo II de Gurupi (TO), com R \$ 1,7 bilhăo, 85,7\% voltados para o setor de energia elétrica; e a de Porto Nacional (TO), com $\mathrm{R}$ \$ 1,5 bilhão, 52,9\% voltado para o transporte rodoviário e 42,5\%, para o ferroviário.

Por sua vez, na regiáo Nordeste, para as AIRs, entre 2000 e 2018, os maiores desembolsos estiveram centrados nas aglomeraçóes das áreas urbanas consolidadas que se encontram nas capitais e suas proximidades, com localização predominante nas áreas litorâneas dos estados. Esse é o caso de Salvador (BA), com mais de R \$ 13,4 bilhóes, destinados, sobretudo, ao setor de transporte rodoviário (52,2\%) e telecomunicaçôes $(23,3 \%)$; de Recife (PE), com cerca de R $\$ 7,8$ bilhóes, canalizados, predominantemente, para energia elétrica $(36,6 \%)$ e telecomunicaçôes $(32,1 \%)$; de Suape (PE),$^{12}$ com R \$ 1,9 bilhão, aplicados, principalmente, na infraestrutura do Complexo Portuário de Suape (39,5\%) e do setor de energia elétrica (29,1\%); da AIP de Catu (BA), ${ }^{13}$ com R \$ 6,2 bilhōes, orientados, em grande medida, à infraestrutura de petróleo e gás do Gasoduto de Integração Sudeste-Nordeste (Gasene); ; ${ }^{14}$ de Fortaleza (CE), com R \$ 5,3 bilhôes, guiados para transporte rodoviário $(58,9 \%)$ e energia elétrica $(13,1 \%)$; da AIP do tipo de II Baixo Curu (CE), com R \$ 5,1 bilhôes, voltados, principalmente, para o setor de energia elétrica (69,3\%); da AIP do tipo I de Itapipoca (CE), com R \$2,0 bilhôes, designados, majoritariamente, ao setor de energia elétrica (98,7\%); da Aglomeração Urbana de São Luís (MA), ${ }^{15}$ com cerca de $\mathrm{R} \$ 4,1$ bilhóes, destinados à infraestrutura de energia elétrica (51,0\%) e rodoviária (21,7\%); e de João Pessoa (PB), com R \$ 2,0 bilhóes, vinculados, grosso modo, aos setores de energia elétrica (52,3\%) e transporte rodoviário $(27,6 \%)$.

12. AlP do tipo I em 2000 e AIR a partir de 2005.

13. AlP do tipo II em 2000 e tipo II a partir de 2005.

14. 0 projeto do Gasoduto de Integração Sudeste-Nordeste (Gasene) apresenta capacidade de transportar 20 milhões de metros cúbicos/dia de gás natural e por 1.387 km, interligando o terminal de Cabiúnas, em Macaé (RJ), a unidade da Petrobras Transporte S. A. (Transpetro), em Catu (BA). No estado da Bahia, o gasoduto perpassa vários municípios, o que vem a favorecer a distribuição de gás e sua interiorização. 0 gás natural transportado pelo Gasene também pode seguir para outros estados da região, por meio de dutos da Malha Nordeste (Bacellar e Nali, 2014a).

15. AlP do tipo I em 2000 e AIR a partir de 2010. 
Para além das capitais e suas proximidades na faixa litorânea, no mesmo período, destaque é dado, ainda que em menor escala, para as aglomeraçôes localizadas no interior, com desembolsos voltados principalmente para a infraestrutura de energia elétrica, como: a AIP do tipo II de Guanambi (BA), com cerca de R \$ 4 bilhóes, 95,5\%, voltados ao setor de energia elétrica; o Médio Mearim (MA), ${ }^{16}$ com mais de R\$ 1,6 bilhão, 95,1\% destinados a projetos do Complexo Termoelétrico Parnaíba ${ }^{17}$ (95,1\%); a aglomeração de Mossoró ( $\mathrm{RN}),{ }^{18}$ com $\mathrm{R} \$ 1,6$ bilhão, 87,2\% canalizados para o setor de energia elétrica; e a AIP do tipo II de Juazeiro (BA), com R \$ 1,4 bilhão, 98,1\% destinados à infraestrutura de energia elétrica.

No Centro-Oeste, entre 2000 e 2018, as aglomerações com maior volume de desembolsos tenderam a estar nas aglomeraçóes das capitais e espalhadas pelo interior, de modo geral, com intensa evolução dos investimentos sobre o sistema rodoviário. Entre as principais microrregióes, a AIR de Brasília (DF) foi a que mais absorveu recursos, R \$ 16,8 bilhôes, destinados, especialmente, ao setor de telecomunicaçôes (59,0\%), mais especificamente para empresas de telefonia fixa e móvel que operam na região e transporte rodoviário $(20,3 \%)$.

Em Goiás, a AIR da capital, Goiânia (GO), deteve cerca de R \$ 4,0 bilhóes, centrados na infraestrutura de transporte rodoviário (79,7\%). No interior do estado, sobressaem as aglomeraçóes de Quirinópolis (GO), ${ }^{19}$ com R \$ 2,0 bilhôes, voltados, predominantemente, ao transporte rodoviário $(65,4 \%)$ e aos serviços de utilidade pública $(21,9 \%)$; e de Sudoeste de Goiás (GO), ${ }^{20}$ com mais de R \$ 1,7 bilhão, designados, principalmente, ao transporte rodoviário (74,7\%) e à energia elétrica (25,0\%).

Em Mato Grosso, a AIR da capital, Cuiabá (MT), recebeu R\$ 3,0 bilhóes, majoritariamente para o transporte ferroviário (54,3\%) e rodoviário (35,8\%). Além da aglomeração da capital são destaques Alto Teles Pires (MT), ${ }^{21}$ com mais de R \$ 1,2 bilhão,

16. AlP do tipo II em 2015.

17. 0 Complexo Termelétrico Parnaíba consiste em um conjunto de parques termoelétricos elétricos que utilizam gás na geração de energia, extraído de campos localizados nas proximidades do complexo. Possui capacidade instalada de 1,4 GW, e representa a capacidade de geração elétrica a gás do Brasil (Bacellar e Nali, 2014a).

18. AlP do tipo I até 2005 e AIR a partir de 2010.

19. AIP do tipo I em 2005 e AIP do tipo II a partir de 2010.

20. AIP do tipo I em 2000 e AIR a partir de 2005.

21. AlP do tipo II até 2005 e AIR a partir de 2010.

\section{4}


voltados, de modo geral, aos setores de transporte rodoviário (66,0\%) e atividades auxiliares de transporte e entrega (19,5\%); AIP do tipo II de Colíder (MT), com R\$ 1,4 bilhão, designados, em grande medida, ao setor de energia elétrica (\%); e Rondonópolis (MT), com cerca de $\mathrm{R} \$ 3,5$ bilhóes, destinados ao transporte rodoviário $(78,8 \%)$.

Em Mato Grosso do Sul, a AIR de sua capital, Campo Grande (MS), concentrou R \$ 3,0 bilhōes, principalmente sobre a atividade do setor rodoviário $(76,9 \%)$. Adicionalmente, outra microrregiáo que sobressai é Dourados (MS), ${ }^{22}$ com R $\$ 1,2$ bilhão, destinado, predominantemente, a transporte rodoviário $(55,0 \%)$ e energia elétrica $(28,4 \%)$.

A tabela 6 apresenta o volume de recursos para a infraestrutura nas trinta principais aglomeraçóes, nos períodos 2000-2004, 2005-2009, 2010-2014 e 2015-2018. Assim como nos resultados para a indústria, atesta-se a centralidade de regiốes do polígono e sua extensão como demandantes de recursos. No entanto, um conjunto de localidades no Norte e Nordeste se destacam em alguns períodos, como a microrregiáo de Tucuruí (PA), Palmas (TO), Porto Velho (RO), Imperatriz (MA), Aglomeração Urbana de São Luís (MA), Catu (BA), Salvador (BA), Guanambi (BA), Juazeiro (BA), Senhor do Bonfim (BA), Fortaleza (CE), Litoral de Camocim e Acaraú (CE), Mossoró (RN), Recife (PE) e Suape (PE). Mesmo na ausência de uma continuidade sólida da atuação no tempo, este resultado reforça a percepção de atuação da instituição em favor da consolidação de infraestrutura fora do eixo tradicional (Sul-Sudeste).

Adicionalmente, em meio ao período de crescimento generalizado dos desembolsos do BNDES (2000-2014), a participação das trinta maiores aglomeraçôes reduziu paulatinamente. No período 2000-2004, essas AIRs e AIPs (tipo I e II) representavam 80,0\% do total dos recursos; nos períodos subsequentes, 2005-2009 e 2010-2014, a participação foi respectivamente de $61,5 \%$ e $57 \%$. Tal inflexão só foi amenizada no período 2015-2018, quando os desembolsos chegaram ao patamar de 59,7\%. Esse processo sinaliza para uma desconcentração dos desembolsos entre as aglomerações, assim como observado nos desembolsos para a indústria.

22. AIP do tipo I em 2000 e AIR a partir de 2005. 
TABELA 8

Total dos desembolsos e posição das trinta principais aglomerações industriais na absorção de recursos, em períodos selecionados ${ }^{1,2}$

(Em R\$ milhões)

\begin{tabular}{|c|c|c|c|c|c|c|c|c|}
\hline \multirow[b]{2}{*}{ Posição } & \multicolumn{2}{|c|}{ De 2000 a 2004} & \multicolumn{2}{|c|}{ De 2005 a 2009} & \multicolumn{2}{|c|}{ De 2010 a 2014} & \multicolumn{2}{|c|}{ De 2015 a 2018} \\
\hline & $\begin{array}{l}\text { Aglomeração } \\
\text { industrial }\end{array}$ & Total & $\begin{array}{l}\text { Aglomeração } \\
\text { industrial }\end{array}$ & Total & $\begin{array}{l}\text { Aglomeração } \\
\text { industrial }\end{array}$ & Total & $\begin{array}{l}\text { Aglomeração } \\
\text { industrial }\end{array}$ & Total \\
\hline 1 & São Paulo & $12.010,43$ & São Paulo & $21.077,02$ & Rio de Janeiro & $37.697,44$ & Rio de Janeiro & $13.760,41$ \\
\hline 2 & Rio de Janeiro & $10.975,43$ & Rio de Janeiro & $19.494,06$ & São Paulo & $21.054,27$ & São Paulo & $8.273,97$ \\
\hline 3 & Brasília & $8.692,86$ & Porto Velho & $7.955,18$ & Porto Velho & $18.225,41$ & Santos & $2.339,69$ \\
\hline 4 & Campinas & $5.340,68$ & Belo Horizonte & $6.087,79$ & Belo Horizonte & $8.598,20$ & Litoral Lagunar & $2.015,39$ \\
\hline 5 & Salvador & $4.878,22$ & Catu & $5.913,45$ & Curitiba & $7.181,71$ & Curitiba & $1.821,45$ \\
\hline 6 & Tucuruí & $3.989,73$ & Manaus & $5.467,28$ & Campinas & $6.947,21$ & Porto Velho & $1.638,74$ \\
\hline 7 & Belo Horizonte & $3.315,45$ & Curitiba & $5.241,72$ & Guarulhos & $5.533,64$ & Belo Horizonte & $1.483,70$ \\
\hline 8 & Porto Alegre & $2.554,70$ & Vitória & $4.914,00$ & Santos & $4.452,11$ & Maringá & $1.414,99$ \\
\hline 9 & Curitiba & $2.453,30$ & Campinas & $4.058,60$ & Porto Alegre & $4.341,49$ & Salvador & $1.409,28$ \\
\hline 10 & Macaé & $2.296,40$ & Brasília & $3.910,23$ & Salvador & $3.938,34$ & Guanambi & $1.379,24$ \\
\hline 11 & Vitória & $1.669,03$ & Salvador & $3.262,70$ & Vitória & $3.634,69$ & Campinas & $1.313,68$ \\
\hline 12 & Curitibanos & $1.589,52$ & Recife & $3.049,87$ & Brasilia & $3.571,22$ & Itajaí & $1.216,03$ \\
\hline 13 & Fortaleza & $1.544,86$ & Porto Alegre & $2.909,56$ & Itajaí & $3.482,73$ & Porto Alegre & $1.143,13$ \\
\hline 14 & Palmas & $1.477,67$ & Cuiabá & $2.752,41$ & Baía da Ilha Grande & $3.246,33$ & Juazeiro & $1.009,20$ \\
\hline 15 & Itajaí & $1.422,19$ & Caxias do Sul & $2.315,30$ & $\begin{array}{l}\text { Campos dos } \\
\text { Goytacazes }\end{array}$ & $3.140,40$ & Mossoró & 986,90 \\
\hline 16 & Recife & $1.337,70$ & Santos & $1.973,08$ & Osasco & $2.964,54$ & Pirapora & 839,09 \\
\hline 17 & Vacaria & $1.314,39$ & Goiânia & $1.441,31$ & Recife & $2.729,24$ & Suape & 756,41 \\
\hline 18 & Manaus & $1.117,07$ & Fortaleza & $1.433,01$ & Guanambi & $2.564,42$ & $\begin{array}{l}\text { Senhor do } \\
\text { Bonfim }\end{array}$ & 754,36 \\
\hline 19 & Gurupi & $1.008,70$ & Guarulhos & $1.324,21$ & Ribeirão Preto & $2.483,14$ & $\begin{array}{l}\text { Litoral de } \\
\text { Camocim e } \\
\text { Acaraú }\end{array}$ & 753,76 \\
\hline 20 & Concórdia & 982,42 & Maringá & $1.319,67$ & Goiânia & $2.412,23$ & Itapipoca & 705,34 \\
\hline 21 & João Pessoa & 960,91 & Osasco & $1.318,23$ & Joaçaba & $2.304,29$ & Recife & 670,22 \\
\hline 22 & Jundiaí & 945,47 & Joinville & $1.275,88$ & Joinville & $2.286,28$ & Brasília & 665,43 \\
\hline 23 & Santos & 842,17 & $\begin{array}{l}\text { Aglomeração } \\
\text { Urbana de São } \\
\text { Luís }\end{array}$ & $1.239,28$ & Maringá & $2.255,70$ & Osasco & 654,72 \\
\hline 24 & Imperatriz & 685,79 & Juiz de Fora & $1.218,10$ & Cuiabá & $2.145,11$ & Garanhuns & 641,08 \\
\hline 25 & Maceió & 651,56 & Uberlândia & $1.202,43$ & Caxias do Sul & $2.139,06$ & Manaus & 636,98 \\
\hline 26 & Goiânia & 648,54 & $\begin{array}{l}\text { São José do } \\
\text { Rio Preto }\end{array}$ & $1.083,83$ & $\begin{array}{l}\text { Aglomeração Urba- } \\
\text { na de São Luís }\end{array}$ & $2.066,52$ & Guarulhos & 636,38 \\
\hline 27 & Uberlândia & 633,06 & Lins & $1.078,29$ & Manaus & $2.012,81$ & Jundiaí & 634,32 \\
\hline 28 & Campo Grande & 628,36 & Londrina & $1.075,02$ & Fortaleza & $1.946,14$ & Joinville & 512,69 \\
\hline
\end{tabular}




\begin{tabular}{|c|c|c|c|c|c|c|c|c|}
\hline \multirow[b]{2}{*}{ Posição } & \multicolumn{2}{|c|}{ De 2000 a 2004} & \multicolumn{2}{|c|}{ De 2005 a 2009} & \multicolumn{2}{|c|}{ De 2010 a 2014} & \multicolumn{2}{|c|}{ De 2015 a 2018} \\
\hline & $\begin{array}{l}\text { Aglomeração } \\
\text { industrial }\end{array}$ & Total & $\begin{array}{c}\text { Aglomeração } \\
\text { industrial }\end{array}$ & Total & $\begin{array}{l}\text { Aglomeração } \\
\text { industrial }\end{array}$ & Total & $\begin{array}{l}\text { Aglomeração } \\
\text { industrial }\end{array}$ & Total \\
\hline 29 & Caxias do Sul & 614,56 & Osório & $1.063,87$ & Uberlândia & $1.902,23$ & Rondonópolis & 511,33 \\
\hline 30 & $\begin{array}{l}\text { Aglomeração } \\
\text { urbana de São } \\
\text { Luís }\end{array}$ & 572,66 & Ribeirão Preto & $1.031,30$ & Chapecó & $1.843,44$ & Macapá & 498,40 \\
\hline Total das & ta principais & $77.153,82$ & & $117.486,70$ & & $169.100,32$ & & $51.076,31$ \\
\hline $\begin{array}{l}\text { Total do } \\
\text { infraestr }\end{array}$ & embolsos para a & $96.428,25$ & & $191.019,96$ & & $296.569,88$ & & $85.556,86$ \\
\hline
\end{tabular}

Fonte: BNDES (2020).

Elaboração dos autores.

Notas: ' Valores monetários deflacionados pelo IGP-DI, da FGV, a preços de 2018. 2 Dados de desembolsos apenas de municípios especificados.

Com o objetivo de aferir o nível de concentração dos desembolsos na infraestrutura, utilizamos o índice de Gini Herfindahl-Hirschman (IHH), para cada um dos períodos analisados. Os resultados são 0,23 (2000-2004); 0,19 (2005-2009); 0,19 (2010-2014); e 0,23 (2015-2018), configurando, nesses termos, um processo de desconcentração, ainda que modesto, no período de ascensão dos desembolsos e um retorno à concentração, em meio à redução da atuação do BNDES.

$\mathrm{Na}$ análise dos desembolsos, em termos absolutos, para as aglomeraçôes, percebe-se uma atuação do banco semelhante à observada na indústria, orientada, principalmente, para as regiôes industriais mais maduras e seu entorno, e, pontualmente, em outras localidades. No entanto, ao analisar a variação dos recursos, em termos relativos, nas AIRs, AIPs e microrregióes com menos de mil empregos industriais, particularmente em meio à ascensão dos desembolsos, é evidente o esforço do BNDES em prol de uma mudança estrutural no território, com o aumento da pujança dos investimentos, principalmente nas microrregiốes do Centro-Oeste, Norte e Nordeste (mapa 4).

O crescimento dos desembolsos nos períodos 2000-2004 e 2005-2009 ocorreu, de modo mais intenso, nas regióes Sudeste, Sul e Centro-Oeste. Também é possível notar que no Norte e Nordeste há diversas regiōes que não apresentaram crescimento. As regiôes Sudeste e Centro-Oeste destacam-se por conterem 105 das 174 microrregióes com ganhos acima de dez vezes da média nacional (gráfico 4). Nos períodos de crescimento subsequentes, 2005-2009 e 2010-2014, o número de microrregióes com ganhos acima de dez vezes acima da média nacional caem significativamente em todas regióes. No entanto, é possível observar que esta queda é menos intensa nas microrregiôes do Norte e Nordeste, o que contribui para que estas regiôes ganhem maior representatividade nos grupos de ganhos acima de dez vezes da média nacional (mapa 4 e gráfico 4). 
MAPA 4

Microrregiões do Brasil: crescimento dos desembolsos do BNDES para infraestrutura, segundo grupos, em períodos selecionados ${ }^{1,23}$

3A - Crescimento dos desembolsos entre os períodos 2000-2004 e 2005-2009

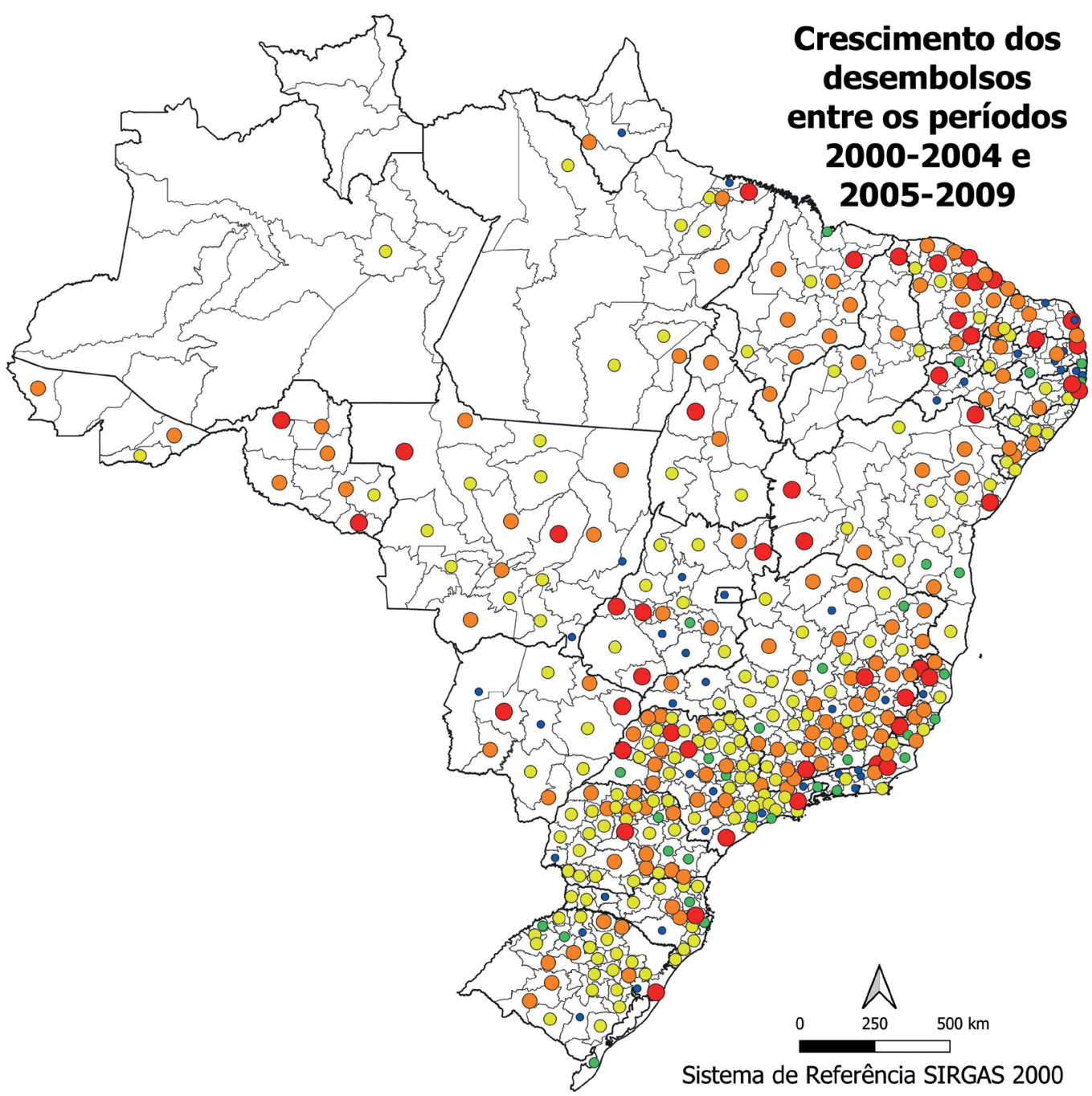

Grupo de microrregiões segundo

o crescimento de desembolsos

- abaixo da média nacional [41]

- entre a média e até 2 vezes a média nacional [31]

- acima de 2 vezes e até 10 vezes a média nacional [157]

- acima de 10 vezes e até 50 vezes a média nacional [128]

- acima de 50 vezes a média nacional [46] 


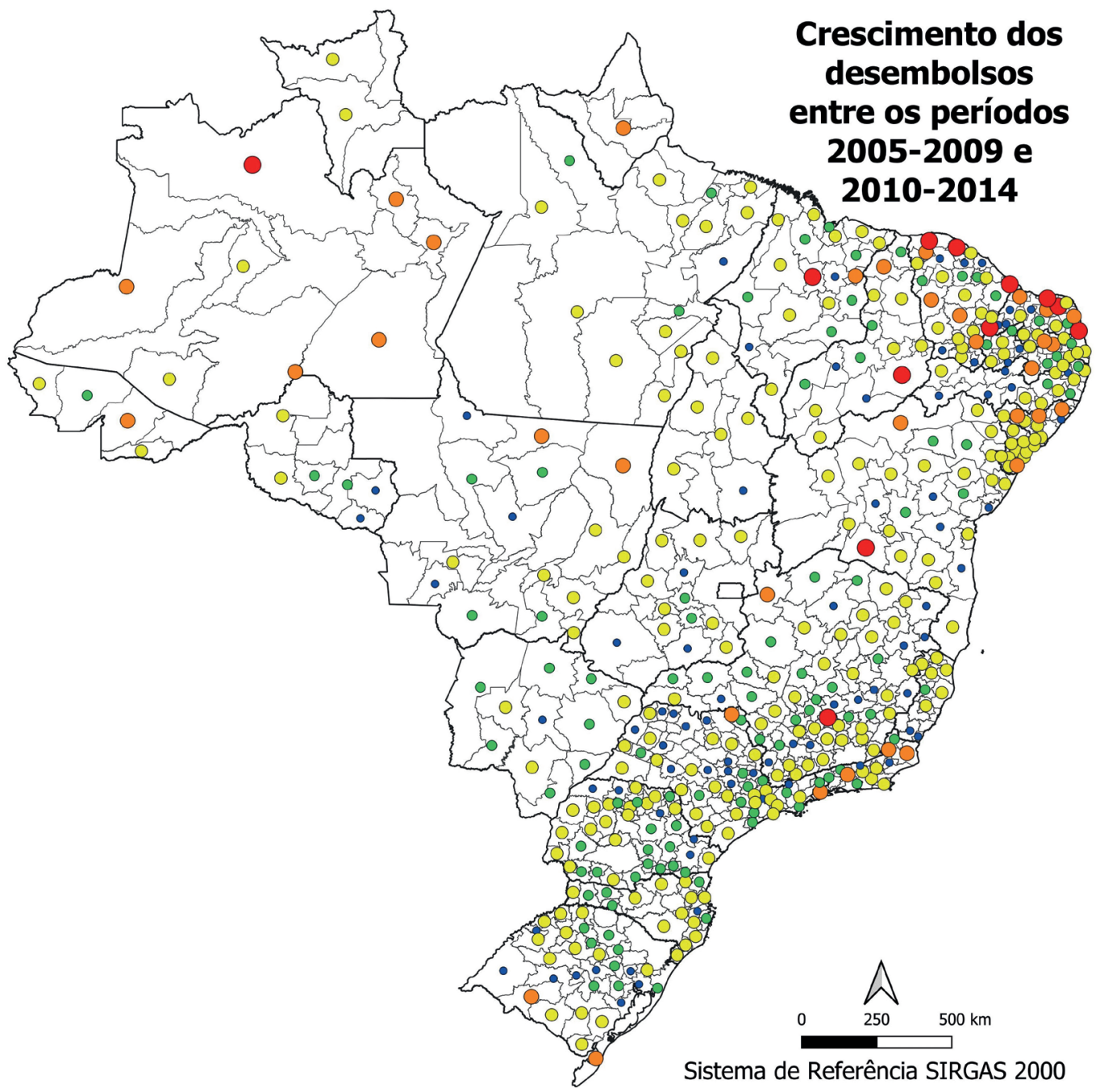

\section{Grupo de microrregiões segundo}

o crescimento de desembolsos

- abaixo da média nacional [81]

- entre a média e até 2 vezes a média nacional [109]

- acima de 2 vezes e até 10 vezes a média nacional [227]

- acima de 10 vezes e até 50 vezes a média nacional [33]

- acima de 50 vezes a média nacional [12]

Elaboração dos autores.

Notas: ' Valores monetários deflacionados pelo IGP-DI, da FGV, a preços de 2018.

${ }^{2}$ Dados de desembolsos apenas de municípios especificados.

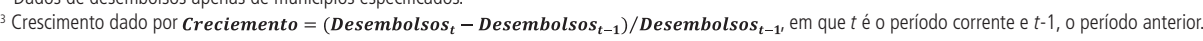


Muito embora o total de recursos destinados a cada uma dessas microrregióes seja diminuto quando comparado aos volumes destinados às regióes preferenciais (área do polígono e sua expansão, bem como o litoral e as principais capitais e seu entorno), esse esforço denota relevância, pois indica o aumento do esforço de alterar a infraestrutura local.

\section{GRÁFICO 4}

Número de microrregiões com crescimento de desembolsos, segundo a região e a intensidade de crescimento, entre períodos selecionados

(Em \%)

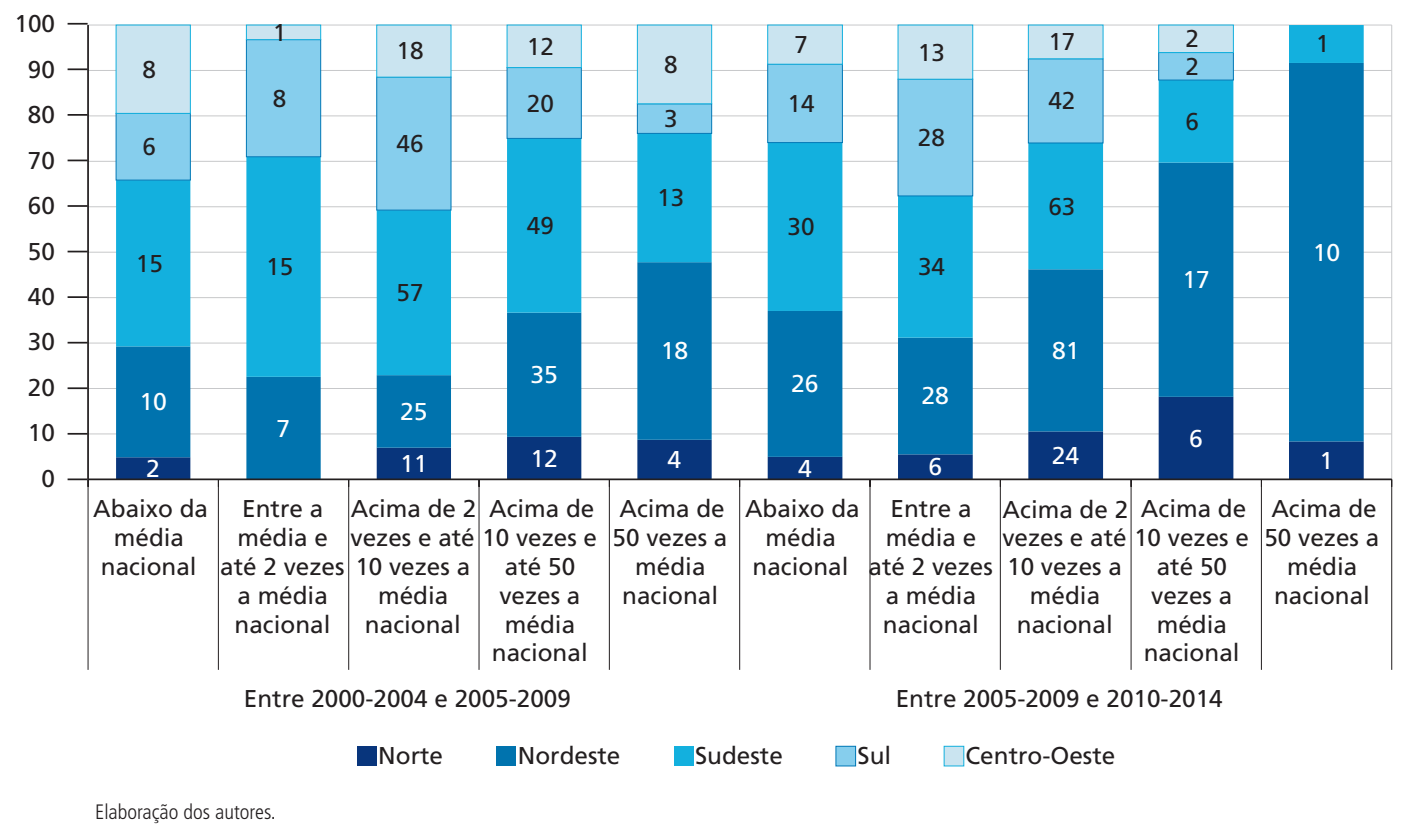

Em suma, as aglomeraçóes do Sudeste-Sul preservam grande relevância ao concentrarem parcela significativa dos desembolsos para a infraestrutura, sobretudo em suas aglomeraçóes industriais acima de 10 mil empregados. A regiáo Sudeste mantém relativa estabilidade em sua participaçáo nos desembolsos, ao passo que a região Sul apresenta crescimento em sua parcela nos desembolsos, guiada, principalmente, por suas AIRs. Na região Norte as AIPs do tipo I e II são as que mais absorvem os recursos para a infraestrutura, voltados, predominantemente, para os setores de transporte e energia elétrica. No Nordeste as AIRs foram predominantes na absorção dos recursos, entretanto a regiáo apresenta queda na participaçáo dos recursos destinados às AIRs, ao passo que as aglomeraçóes com menos de 10 mil empregos revelam notória 
evolução nos recursos. Ademais, nesta região os desembolsos estiveram canalizados, principalmente, para o setor de energia elétrica. No Centro-Oeste as AIRs preservaram a maior participação nos desembolsos, pelo menos até 2010-2014, no entanto a evoluçáo dos recursos nas aglomeraçóes com menos de 10 mil ocupaçóes sobressai ao observado nas AIRs, direcionados, especialmente, aos setores de transporte rodoviário e energia elétrica.

\section{CONCLUSÕES}

O esforço aqui empreendido buscou identificar o padrão distributivo dos desembolsos do BNDES para a indústria (extrativa e de transformação) e a infraestrutura, em múltiplas escalas regionais (desde as macrorregióes até as microrregióes), setoriais e por tamanho da aglomeração industrial, entre os anos de 2000 e 2018, no Brasil.

Em termos mais gerais, percebe-se que o BNDES, no período recente, ampliou sua atuação sobre a indústria brasileira, especialmente no seu ciclo mais intenso de atuação (2000-2014). A região Sudeste, muito embora detenha a maior parcela dos recursos para a indústria, apresentou redução de 11,6 p.p. no total dos desembolsos nos períodos 2000-2004 e 2015-2018. Por sua vez, as regióes Sul e Centro-Oeste foram aquelas com maior aumento da participação na parcela dos desembolsos, 6,7 p.p. e 3,4 p.p respectivamente. Resultados que se aproximam da evolução da atividade industrial recente nessas regióes, discutida em Monteiro Neto e Silva (2018). As regióes Nordeste e Norte, apesar dos resultados mais tímidos, também apresentaram ganhos no mesmo período, 0,2 p.p. e 1,3 p.p. respectivamente.

No aspecto setorial, os principais financiamentos foram para as atividades previstas nos programas para fortalecer a competitividade e consolidar e expandir a liderança da PDP, como a fabricação de produtos alimentícios; veículos, carrocerias e reboque; coque, petróleo e combustivel, outros equipamentos de transporte; metalurgia; e celulose e papel, que juntos somam $63,8 \%$ do total dos desembolsos para a indústria. Somente os setores de produtos alimentícios e coque, petróleo e combustivel, pertencentes ao grupo de atividades baseadas em recursos naturais que apresentaram crescimento do valor de transformação industrial mais intenso nos anos 2000 (Monteiro Neto e Silva, 2018), e receberam 25,9\% do total dos desembolsos entre 2000 e 2018. 
No que concerne à localização dessas aglomeraçóes, aquelas com grandes volumes de desembolsos são poucas e distribuídas, predominantemente, na área do "polígono" descrito por Diniz e Crocco (1996). De modo geral, configura-se um padráo de atuação com grandes investimentos em três eixos: i) Sul-Sudeste e seu transbordo; ii) as principais capitais e áreas em seu entorno; e iii) a faixa litorânea da região Nordeste. Estas também tenderam a permanecer as mesmas no período analisado, muito embora mudanças mais ou menos pontuais sejam verificáveis, como os investimentos em nova áreas, tais como: i) na expansão dos desembolsos no entorno do "polígono", sobretudo no Sul, no vetor Rio-Vitória e Centro-Oeste; e ii) em algumas operaçóes no Norte e Nordeste.

Em termos do tamanho do emprego nas aglomeraçóes industrias, percebe-se que aquelas localizadas no eixo Sudeste-Sul preservam grande relevância ao concentrarem parcela significativa dos desembolsos para a indústria, sobretudo em aglomeraçôes industriais acima de 10 mil empregados. A regiāo Sudeste, embora tenha a primazia nos desembolsos, vem perdendo paulatinamente sua participação em todos os tipos de aglomeraçóes. A regiáo Sul, por sua vez, apresenta crescimento em sua parcela, guiada, principalmente, por suas AIRs. Na regiăo Norte, apesar de as AIRs absorverem a maior parcela dos recursos, são em suas AIPs (do tipo I e II) que o crescimento e a dinâmica dos desembolsos se revelam de modo mais intenso. No Norte os principais agrupamentos beneficiados foram aqueles abaixo de 10 mil empregos industriais. No Centro-Oeste foram mais favorecidas, ao longo do período de crescimento de desembolsos do BNDES (2000-2014), as AIRs e as AIPs do tipo I. Muito embora haja permanência do padrão geral de distribuição, é possível observar certo grau de desconcentração da atuação do BNDES no sentido das regióes alvo da política regional.

No que se refere às trajetórias dos desembolsos sobre a infraestrutura das aglomerações industriais, as aglomerações do eixo Sudeste-Sul também preservam grande relevância, concentrando parcela significativa dos recursos para a infraestrutura, especialmente em suas aglomeraçóes industriais acima de 10 mil empregados. A região Sudeste mantém relativa estabilidade em sua participaçáo nos desembolsos, ao passo que a regiâo Sul apresenta crescimento em sua parcela nos desembolsos, guiada, principalmente, por suas AIRs. Na regiáo Norte as AIPs do tipo I e II são as que mais absorveram os recursos para a infraestrutura, voltados, predominantemente, para o setor de transporte e energia elétrica. No Nordeste as AIRs foram predominantes na absorção dos 
recursos, entretanto a região apresenta queda na participação dos recursos destinados às AIRs, ao passo que as aglomeraçôes com menos de 10 mil empregos revelam notória evoluçấo nos recursos. Ademais, no Nordeste os desembolsos estiveram canalizados, principalmente, para o setor de energia elétrica. No Centro-Oeste as AIRs preservaram a maior participação nos desembolsos, pelo menos até 2010-2014, no entanto a evolução dos recursos nas aglomeraçôes com menos de 10 mil ocupaçôes sobressai ao observado nas AIRs. Os desembolsos na região estiveram voltados, especialmente, aos setores de transporte rodoviário e energia elétrica.

Em suma, com base no material investigado e discutido, pode-se concluir que no período recente o BNDES ampliou sua atuação em todas as macrorregiôes, demonstrando, ainda que em escala modesta, um processo de desconcentração. As grandes aglomeraçóes industriais mais consolidadas ainda preservam grande relevância na absorção dos recursos (tanto na indústria quanto na infraestrutura) e estão localizadas, principalmente, na proximidade das principais capitais e da faixa litorânea do Nordeste. No entanto, é possível notar uma atuação do BNDES em prol das aglomeraçóes de menor tamanho, sobretudo aquelas pertencentes às regióes alvo da política regional, processo este que pode refletir em edificação de novos arranjos produtivos locais. Cabe frisar que a lógica operacional do banco (em que os recursos são disponibilizados essencialmente responsivos às demandas que recebe) e a sua estrutura enxuta (que implica a necessidade de bancos comerciais parceiros para os repasses) podem refletir sobre sua dificuldade de se aproximar efetivamente de dinâmicas genuinamente regionais. Nesses termos, uma agenda de pesquisa relevante é compreender estratégias operacionais e políticas públicas que possam aprimorar a atuação deste importante banco de desenvolvimento no território nacional.

\section{REFERÊNCIAS}

ALBUQUERQUE, B. E. et al. Os bancos de desenvolvimento e o papel do BNDES. Rio de Janeiro: BNDES, 2018. (Texto para Discussão, n. 133).

ALMEIDA, J. S. G. A política de desenvolvimento produtivo. São Paulo: Iedi, 2008.

BACELLAR, R. M. H; NALI, E. C. O apoio à indústria de base na regiáo Nordeste. In: GUIMARÃES, P. F. et al. Um olhar territorial para o desenvolvimento: Nordeste. Rio de Janeiro: BNDES, 2014a. 
O apoio à indústria de base na regiāo Nordeste. In: CAVALVANTE, I. M. et al. Um olhar territorial para o desenvolvimento: Centro-Oeste. Rio de Janeiro: BNDES, $2014 \mathrm{~b}$.

BARBOZA, R. M.; FURTADO, M.; GABRIELLI, H. A atuação histórica do BNDES: o que os dados têm a nos dizer? Rio de Janeiro: BNDES, 2018. (Texto para Discussão, n. 123).

BARROS, J. R. M.; GOLDENSTEIN, L. Avaliação do processo de reestruturação industrial brasileiro. Revista de Economia Política, São Paulo, Centro de Economia Política, v. 17, n. 66, abr./jun. 1997.

BNDES - BANCO NACIONAL DE DESENVOLVIMENTO ECONÔMICO E SOCIAL. Resolução 902/97, de 3 de julho 1997. Rio de Janeiro: BNDES, 1997.

BNDES alavanca com R $\$ 10$ bilhôes projetos de geração de energia elétrica. Portal BNDES, jun. 2004. Disponível em: <https://bit.ly/39gZjgU>.

Relatório Anual BNDES, 2010. Rio de Janeiro: BNDES, 2011.

BNDES aprova financiamento de R \$ 2,3 bilhões para Siderúrgica do Pecém. Portal BNDES, 30 abr. 2015. Disponível em: <https://bit.ly/39ccLCV>. Acesso em: 19 abr. 2020.

BNDES conclui pré-pagamento de R 130 bilhóes ao Tesouro e antecipação chega a R\$ 310 bi desde 2015. Portal BNDES, 21 ago. 2018. Disponível em: <https://bit. ly/2LNrtXs>. Acesso em: 11 jan. 2021.

Com novo programa, BNDES amplia acesso ao crédito para setores intensivos em tecnologia. Portal BNDES, 2019. Disponível em: <https://bit.ly/3fBAzRC>. Acesso em: 5 maio 2019.

BRAGA, I. M.; RAMOS, R. O BNDES e a questão energética e logística da região Amazônia. In: SIFFERT FILHO, N. F. et al. (Orgs.). Um olhar territorial para o desenvolvimento: Amazônia. Rio de Janeiro: BNDES, 2014.

CAMPOS, R. Q.; LEAL, R. M.; RAMOS, R. O BNDES e a questão energética e logística da região Nordeste: os desafios da integração regional. In: GUIMARÁES, P. F. et al. (Org). Um olhar territorial para o desenvolvimento: Nordeste. Rio de Janeiro: BNDES, 2014.

CODATO, A. N. Sistema estatal e política econômica no Brasil pós-64. São Paulo: Editora Hucitec, 1997.

CSP - COMPANHIA SIDERÚRGICA DO PECÉM. Nossa história. CSP, 2020. Disponível em: <https://bit.ly/38HN6Bb>. Acesso em: 11 jan. 2021.

DE NEGRI, J.; DE NEGRI, F.; ALVEZ, P. Os financiamentos do BNDES têm impacto positivo sobre a tecnológica, o emprego e o faturamento das firmas? Brasília: Ipea, 2008. Mimeografado. 
DINIZ, C. C. Repensando a questão regional brasileira: tendências, desafios e caminhos. Nova Economia, Belo Horizonte, v.6, n.1, 2002.

Dinâmica regional e ordenamento do território brasileiro: desafios e oportunidades. Belo Horizonte: Cedeplar; UFMG, 2013. (Texto para Discussão, n. 471).

DINIZ, C.; CROCCO, M. Reestruturação econômica e impacto regional: o novo mapa da indústria brasileira. Nova Economia, Belo Horizonte, v. 6, n. 1, p. 77-103, jul. 1996.

FERRAZ, J. C.; ALÉM, A.; MADEIRA, R. A contribuição dos bancos de desenvolvimento para o financiamento de longo prazo. Revista do BNDES, Rio de Janeiro, n. 40, p. 5-42, dez. 2013.

FURTADO, C. Teoria y política del desarrollo económico. Ciudad de México: Siglo XXI, 1968.

GUEDES, A. L. Financiamento do desenvolvimento: pesquisa comparativa dos bancos de desenvolvimento. In: DE NEGRI, J. A.; ARAÚJO, B. C.; BACELETTE, R. (Orgs.). Desafios da nação: artigos de apoio. Brasília: Ipea, 2018. v. 1.

JENKS, G. F. Optimal data classification for choropleth maps. Kansas: University of Kansas, 1977. (Occasional Paper).

KALDOR, N. Causes of the slow rate of economic growth of the United Kingdom: an inaugural lecture. Louvain Economic Review, London, 1966.

LASTRES, H. M. M. et al. O apoio ao desenvolvimento regional: a experiência do BNDES e oportunidades para avanços. Revista do BNDES, Rio de Janeiro, n. 42, p. 5-46, dez. 2014.

LIBÂNIO, G.; MORO, S. Manufacturing Industry and Economic Growth in Latin American: a kaldoriana approach. In: ENCONTRO NACIONAL DE ECONOMIA, 37., 2009, Foz do Iguaçu, Paraná. Anais... Foz do Iguaçu: Anpec, 2009. Disponível em: <https://bit.ly/33h5WMp>. Acesso em: 4 jan. 2019.

MACHADO, L.; ROITMAN, F. B. Os efeitos do BNDES PSI sobre o investimento corrente e futuro das firmas industriais. Revista do BNDES, Rio de Janeiro, n. 44, p. 89-122, dez. 2015.

MARCONI, N.; REIS, C. F. B.; ARAUJO, E. C. O papel da indústria de transformaçáo e das exportaçóes de manufaturas no processo de desenvolvimento dos países de renda média, 2006. Brasília: Ipea, 2014. (Texto para a Discussão, n. 2006).

MILANEZ, A. Y. et al. A atuação da área industrial do BNDES na região Centro-Oeste.

In: CAVALVANTE, I. M. et al. Um olhar territorial para o desenvolvimento: Centro-Oeste. Rio de Janeiro: BNDES, 2014.

MONTEIRO NETO, A.; SILVA, R. O. Desconcentração territorial e reestruturaçáo regressiva da indústria no Brasil: padrōes e ritmos. Brasília: Ipea, 2018. (Texto para Discussão, n. 2402). 
NEVES, M. S. et al. Atuação da área industrial do BNDES na região Nordeste. In: GUIMARÁES, P. F. et al. (Org.). Um olhar territorial para o desenvolvimento: Nordeste. Rio de Janeiro: BNDES, 2014.

PEREIRA, C. N.; PORCIONATO, G. L.; CASTRO, C. N. Aspectos socioeconômicos da regiāo do Matopiba. Boletim Regional, Urbano e Ambiental, v. 18, p. 47-59, 2018.

PEREIRA, T. R; MITERHOF, M. T. O Papel do BNDES e o financiamento do desenvolvimento: considerações sobre a antecipação dos empréstimos do Tesouro Nacional e a criação da TLP. Economia e Sociedade, Campinas, v. 27, n. 3, p. 875-908, dez. 2018. Disponível em: $<$ https://bit.ly/365CFGD>. Acesso em: 8 maio 2019.

PROCHNIK, M.; PEREIRA, V. Fontes de recursos do BNDES 1995-2007. Revista do BNDES, Rio de Janeiro, v. 14, n. 29, p. 3-33, jun. 2008.

PUGA, F. P.; GABRIELLI, H. O BNDES e o investimento: 2000 a 2016 . Rio de Janeiro: BNDES. 2018. (Texto para Discussão, n 122).

QUAGLIO, G.; PAIVA, C. C. A questão regional e o BNDES: uma análise da conformidade entre a atuação do Banco e a Política Nacional de Desenvolvimento Regional (PNDR). Economia e Sociedade, v. 26, n. 2, p. 337, 2017.

RAMOS, R. L. S.; COTOVIO, A. O BNDES e a questão energética e logística da região Centro-Oeste. In: SIFFERT FILHO, N. F. et al. (Org.). Um olhar territorial para o desenvolvimento: Centro-Oeste. Rio de Janeiro: BNDES, 2014.

SIFFERT FILHO, N. F. et al. O BNDES e a questão energética e logística da região amazônica. In: SIFFERT FILHO, N. F. et al. Um olhar territorial para o desenvolvimento: Amazônia. Rio de Janeiro: BNDES, 2014a.

SIFFERT FILHO, N. F. et al. O BNDES e a questão energética e logística da região Sudeste. In: LEAL, C. F. C. et al. (Orgs.). Um olhar territorial para o desenvolvimento: Sudeste. Rio de Janeiro: BNDES, 2014b.

SIFFERT FILHO, N. F. et al. O BNDES e a questão energética e logística da região Sul. In: SIFFERT FILHO, N. F. et al. (Orgs.). Um olhar territorial para o desenvolvimento: Sul. Rio de Janeiro: BNDES, 2014c.

SIQUEIRA, H.; BRANDÃO, C. O Sudeste na divisão espacial do trabalho no Brasil. In: LEAL, C. F. C. et al. (Orgs.). Um olhar territorial para o desenvolvimento: Sudeste. Rio de Janeiro: BNDES, 2014.

THIRLWALL, A. P. Foreign trade elasticities in centre-periphery models of growth and development. PSL Quarterly Review, v. 36, n. 146, 1983. 


\section{BIBLIOGRAFIA COMPLEMENTAR}

BACELAR, T. Tendências do desenvolvimento regional recente no Brasil. In: BRANDÃO, C.; SIQUEIRA, H. (Orgs.). Pacto federativo, integraçáo nacional e desenvolvimento regional. São Paulo: Fundação Perseu Abramo, 2013.

BNDES - BANCO NACIONAL DE DESENVOLVIMENTO ECONÔMICO E SOCIAL. BNDES 50 anos de desenvolvimento. Rio de Janeiro: BNDES, 2002. Disponível em: <https://bit.ly/2HBVGab>. Acesso em: 7 maio 2019.

BNDES - BANCO NACIONAL DE DESENVOLVIMENTO ECONÔMICO E SOCIAL. BNDES aprova primeira operação do Proinveste: R \$ 512,5 milhóes para Santa Catarina. Portal BNDES,16 ago. 2012. Disponível em: <https://bit.ly/365xJS7>. Acesso em: 19 abr. 2020.

SIFFERT FILHO, N. F. et al. O BNDES e a questão energética e logística da região Nordeste: os desafios da integração regional In: GUIMARÁES, P. F. et al. Um olhar territorial para o desenvolvimento: Nordeste. Rio de Janeiro: BNDES, 2014. 
Ipea - Instituto de Pesquisa Econômica Aplicada

Assessoria de Imprensa e Comunicação

EDITORIAL

\title{
Chefe do Editorial
}

Reginaldo da Silva Domingos

\section{Assistentes da Chefia}

Rafael Augusto Ferreira Cardoso

Samuel Elias de Souza

\section{Supervisão}

Camilla de Miranda Mariath Gomes

Everson da Silva Moura

\section{Editoração}

Aeromilson Trajano de Mesquita

Cristiano Ferreira de Araújo

Danilo Leite de Macedo Tavares

Herllyson da Silva Souza

Jeovah Herculano Szervinsk Junior

Leonardo Hideki Higa

\section{Capa}

Danielle de Oliveira Ayres

Flaviane Dias de Sant'ana

\section{Projeto Gráfico}

Renato Rodrigues Bueno

The manuscripts in languages other than Portuguese published herein have not been proofread.

\author{
Livraria Ipea \\ SBS - Quadra 1 - Bloco J - Ed. BNDES, Térreo \\ 70076-900 - Brasília - DF \\ Tel.: (61) 2026-5336 \\ Correio eletrônico: livraria@ipea.gov.br
}



Composto em adobe garamond pro 12/16 (texto) Frutiger 67 bold condensed (títulos, gráficos e tabelas) Brasilia-DF 



\section{Missão do Ipea}

Aprimorar as políticas públicas essenciais ao desenvolvimento brasileiro por meio da produção e disseminação de conhecimentos e da assessoria ao Estado nas suas decisões estratégicas.

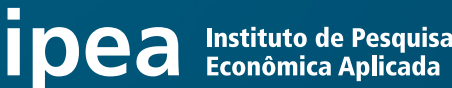 \\ MINISTÉRIO DA \\ ECONOMIA

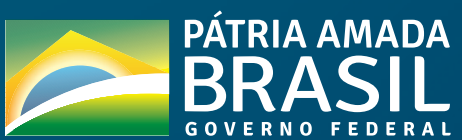

